MARIA AUGUSTA ROCHA PORTO

TEMPO COGNITIVO E TEMPO SOCIAL NAS AULAS DE INGLÊS PARA A ENVELHESCÊNCIA E TERCEIRA IDADE

SÃO CRISTÓVÃO

2017 


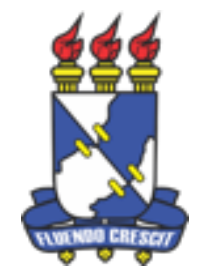

UNIVERSIDADE FEDERAL DE SERGIPE CENTRO DE EDUCAÇÃO E CIÊNCIAS HUMANAS PROGRAMA DE PÓS-GRADUAÇÃO EM EDUCAÇÃO

\title{
TEMPO COGNITIVO E TEMPO SOCIAL NAS AULAS DE INGLÊS PARA A ENVELHESCÊNCIA E TERCEIRA IDADE
}

\author{
MARIA AUGUSTA ROCHA PORTO
}

Tese de doutorado apresentada ao Programa de PósGraduação em Educação da Universidade Federal de Sergipe como requisito parcial para a obtenção do título de doutora em Educação.

Orientadora: Profa. Dra. Raquel Meister Ko Freitag

Co-orientador: Prof. Dr. Héctor Julian Tejada Herrera 
FICHA CATALOGRÁFICA ELABORADA PELA BIBLIOTECA CENTRAL UNIVERSIDADE FEDERAL DE SERGIPE

\section{Porto, Maria Augusta Rocha}

P853t Tempo cognitivo e tempo social nas aulas de inglês para envelhescência e terceira idade. / Maria Augusta Rocha Porto ; orientador Raquel Meister Ko. Freitag. - São Cristóvão, 2017. $101 \mathrm{f}$ : : il.

Tese (doutorado em Educação) - Universidade Federal de Sergipe, 2017.

1. Educação. 2. Idosos - Educação. 3. Envelhecimento. 4. Lingua inglesa - Estudo e ensino. 5. Motivação. I. Freitag, Raquel Meister Ko., orient. II. Título. 
UNIVERSIDADE FEDERAL DE SERGIPE

CENTRO DE EDUCAÇÃO E CIÊNCIAS HUMANAS

PROGRAMA DE PÓS-GRADUAÇÃO EM EDUCAÇÃO

\title{
TEMPO COGNITIVO E TEMPO SOCIAL NAS AULAS DE INGLÊS PARA A ENVELHESCÊNCIA E TERCEIRA IDADE
}

\author{
MARIA AUGUSTA ROCHA PORTO \\ Tese de doutorado apresentada ao programa de Programa de \\ Pós-Graduação em Educação da Universidade Federal de \\ Sergipe e aprovada pela Banca Examinadora. \\ Aprovada em 09.10.2017
}

BANCA EXAMINADORA

Profa. Dra. RAQUEL MEISTER KO. FREITAG

Orientadora e Presidente - Programa de Pós-Graduação em Educação

Prof. Dr. HÉCTOR JULIAN TEJADA HERRERA

Co-orientador - Programa de Pós-Graduação em Fisiologia

Profa. Dra. AYANE NAZARELA SANTOS ALMEIDA

Examinadora externa - Universidade Federal do Recôncavo da Bahia

Profa. Dra. SHIRLEY TELES CHAGAS

Examinadora externa - Instituto Federal de Sergipe

Prof. Dr. RENÉ ALAIN SANTANA ALMEIDA

Examinador externo ao programa - Universidade Federal de Sergipe

Profa. Dra. VERÔNICA MARIANO REIS

Examinadora Interna - Programa de Pós-Graduação em Educação

Prof. Dr. LUIZ EDUARDO OLIVEIRA

Examinador Interno - Programa de Pós-Graduação em Educação

SÃo CRISTÓVÃO (SE)

2017 


\section{DEDICATÓRIA}

Aos Prof $f^{a}$. Dr ${ }^{\mathrm{a}}$. Raquel Meister Ko Freitag, Prof. Dr. Héctor Julian Tejada Herrera e ao Prof. Dr. Luiz Eduardo Menezes de Oliveira (supervisor acadêmico e grande incentivador para realização desta tese), que, pela inesgotável disponibilidade, paciência, cuidado, confiança, afeto, enfim, pelas orientações, infinitas revisões, e ordenações do texto, deram linha ao meu moinho de ideias e palavras. Vocês fazem parte da minha vida.

À Maria Luiza, amiga e companheira de trabalho e pesquisa; este trabalho também é seu.

Aos alunos ministrantes e pesquisadores do projeto "A aula de inglês para a terceira idade".

Aos jovens, envelhescentes e terceira idade.

Aos meus pais, Ben-Hur (in memoriam) e Inêz, exemplos de vida, de incentivo nesta caminhada e de compreensão pela constante ausência.

A Paulo Roberto, amadíssimo esposo, pela compreensão da constante ausência nesta segunda trajetória de pesquisa. I love you wherever you are.

A Melanie, Waldyr, Fellipe, filhos queridos com todo carinho. Esta Tese é de vocês também.

A Pedro, genro dedicado, que também participou da leitura e preparação para a apresentação da tese, Isabella e Naianne, noras queridas, com carinho.

A Bento, neto amadíssimo, que participou também da ausência de sua avó durante essa trajetória.

A Ben-Hur Filho e Tirzah, irmãos, amigos, incentivadores, por existirem em minha vida.

A Ben-Hur Neto, meu afilhadíssimo. 


\section{AGRADECIMENTOS}

A Deus, por ter-me fortalecido nos momentos mais difíceis, impedindo-me de declinar desta causa que tanto desejei alcançar.

À Professora Doutora Raquel Meister Ko Freitag, pela orientação e incentivo.

Ao Professor Doutor Héctor Julian Tejada Herrera, pelo estímulo e constante disponibilidade para com os seus doutorandos.

À Professora Inês Oliveira, minha primeira professora orientadora dos meios antrópicos.

À Professora Verônica Mariano, pelo grande incentivo ao longo dessa trajetória.

Aos Professores Doutores Marcelo, Marcos Cabral e Rejane, pela leitura do processo de afastamento, de um ano apenas, para a coleta de dados desta pesquisa.

A Ademir (in memoriam), secretário do Departamento de Letras Vernáculas.

Aos professores do PPGED, pelas aulas ministradas e novos conhecimentos proporcionados ao longo desta jornada.

Ao CONSUL/CONEPE/PROEX/ADUFS/FAPITEC/CEPITEC, pelo apoio recebido.

Aos colegas amigos do DLES, pelo apoio.

Aos doutorandos (2014/2015) Alessandra, Ana Lúcia, Andrea Matos, Aline, Analice, Cristiane, Elissandra, Ferdinando, Glebson, Jairton, Jôse, Marlucy, Rita Simone, Ricardo Tôrres, Patrícia Verônica, Rose, Sammela e Valéria, pelo convívio e estudos.

Aos colegas do Grupo de Estudo GELINS: Bruno, Lucas, Jenilton, Flávia, Andreia, Jaqueline, Rebeca, Cristiane, Ariana, Thaís, Francis, Josilene, pelo convívio diário. E Verônica, companheira de todos os momentos. 
Above all don't fear difficult moments. The best comes from them. (Rita Levi Montalcini- 1909-2012)

Não tema momentos difíceis, o melhor advém deles. (Rita Levi Montalcini - 1909-2012) 


\section{RESUMO}

Em 2025, o Brasil será considerado o quinto maior país do mundo em número de idosos, conforme projeções do Instituto Brasileiro Geográfico e Estatística (IBGE). Diante desse impacto demográfico, demandas por estudos nas áreas socioeconômica, saúde e educação começam a surgir. Políticas implementadas no país, como o Estatuto do Idoso (Lei no 10.741/2003), visam à integração social dos longevos, podendo contribuir com a qualidade de vida, como é o caso de aprender uma nova língua. O objetivo desta tese foi verificar o efeito do tempo, em suas dimensões social e cognitiva, nas aulas de inglês para o público longevo: envelhescentes e pessoas de terceira idade. A dimensão social se refere à mudança nos padrões sociais de consciência sobre envelhecimento, expectativas e motivações relacionadas à escolarização e ao mercado de trabalho que interferem no processo de ensino-aprendizagem de uma língua estrangeira. A dimensão do tempo cognitivo envolve a relação com a linguagem e está ligada a processos fisiológicos que influenciam o aprendizado de uma língua. Para medir os efeitos do tempo social e do tempo cognitivo, no primeiro semestre de 2016, coletamos dados em duas turmas do curso de extensão "A aula de inglês para a terceira idade" ofertado no âmbito da Universidade Federal de Sergipe (UFS) especificamente para o público envelescente e pessoas da terceira idade. A partir do curso de extensão fizemos três estudos. O primeiro estudo teve como objetivo medir o tempo de leitura, em português e em inglês, de modo silencioso e em voz alta, e o controle do movimento ocular (quantidade e duração das fixações e regressões), com três grupos experimentais (jovens, envelhescentes e pessoas da terceira idade), a fim de identificar os efeitos do envelhecimento nos participantes. O padrão estabelecido é que jovens leitores hábeis leem mais rápido, com duração das fixações entre 200 a 250ms, podendo chegar a 350ms. Para outros tipos de leitores, como envelhescentes e pessoas de terceira idade, a variabilidade pode passar de 500ms nas duas vias diretas de leitura: silenciosa e em voz alta (COZIJN; VONKER (2003), RAYNER (2007), DEHAENE (2012)). O grupo de participantes jovens se diferenciou dos outros dois grupos, obtendo o padrão de 200 a $250 \mathrm{~ms}$. Os jovens obtiveram um tempo maior na leitura em inglês do que na leitura em português. Os participantes da terceira idade apresentaram um número muito maior ao estabelecido como padrão de leitura de $500 \mathrm{~ms}$, apresentando um valor de 600-650ms. Nos textos em inglês, o tempo foi maior entre as três categorias. Os participantes leram os textos em inglês de forma silenciosa mais rápido do que em voz alta. O segundo estudo visou a aferir o tempo de planejamento e de execução das aulas do curso de extensão a fim de identificar a demanda de tempo. Cada aula foi planejada e sua execução, documentada, inclusive o tempo de execução de cada uma das atividades que compunham uma aula (A1, A2, A3, A4, A5, A6, A7, A8, A9, A10). O tempo global de execução em ambas as turmas foi inferior ao tempo planejado. Constatamos que, na turma 1, o tempo executado foi de 136,6 min, apresentando uma média de 135,2 min por aula. Nessa turma, as atividades pedagógicas que duraram mais tempo foram as tarefas A1, A2, A4, A7 e A10. Já na turma 2, o tempo das aulas planejadas e executadas resultou numa média de 116,6 min de aula, com maior tempo nas atividades A5, A6 e A8. Considerando os objetivos das duas turmas, a diferença de tempo entre elas está relacionada às atividades sociais previstas no curso: teste emocional e coffee break. Já para as atividades pedagógicas, os alunos demandaram mais tempo para a verificação das aulas anteriores, explicação de vocabulário e atividades extras. Na turma 2, as atividades que demarcaram mais tempo foram direcionadas para leitura em voz alta e silenciosa, revisão de estruturas da língua e discussão sobre culturas das línguas. O terceiro estudo teve por objetivo aferir as reações emocionais dos participantes envelhescentes e da terceira idade do curso de extensão a fim de verificar os efeitos do tempo social. Foram aplicados testes emocionais na entrada e na saída das aulas do referido curso com palavras adjetivas (momento também de aprendizagem) para medir o grau de satisfação em participar das aulas de inglês e analisar as reações que o curso provoca em seus participantes. Os resultados globais apontam que, embora os estudos do envelhecimento mostrem que há uma demanda de tempo maior na execução de tarefas, essa demanda não é um empecilho para a participação em um curso de língua estrangeira. Nossa pesquisa, com a análise do tempo de leitura e movimento ocular, tempo de planejamento e as fichas emocionais, contribui para o aprimoramento de cursos de inglês, com resultados pontuais que podem ser aproveitados para a implementação de componentes curriculares, definição de conteúdo e procedimentos pedagógicos, preparação, adaptação e avaliação de material impresso e digital, bem como para repensar cursos de formação inicial e continuada de professores, a fim de capacitar profissionais para atuarem em um novo mercado de trabalho, como é o caso dos envelhescentes e pessoas de terceira idade.

Palavras-chave: Envelhescente. Terceira idade. Inglês. Tempo de leitura. Motivação. 


\begin{abstract}
Brazil will be considered the fifth largest worldwide country in number of elderly people next 2025 , according to the prospection data by the Brazilian Institute of Geography and Statistics (IBGE, 2014). Beyond this, demographical density impact, demands for more studies at the socioeconomics, Health and Education areas begin to arise. National implemented Policy actions in Brazil as "The Aged People Decree 10.741, October 2003", which aims with the social integration of the longevity people, may contribute with health quality of life, as learning a new language. We elicit for this thesis to verify the effect of time in social and cognitive dimensions into the English classes for the longevity groups: aging and elderly people. The social dimension refers for the social standard changings about being awareness on aging and expectancy and motivations in relation to the scholarships and for the workforce, once it interferes in the teaching and learning processes of a foreign language. The cognitive dimension time that interferes in the foreign learning involves the relation with language, in terms of physiology and its process. For measuring the effects of the cognitive and social timing into the English classes, we realized, in this thesis, three studies based on the data in two different classes as an extension course entitled. "The English class for the aging people", at the first semester of 2016 length time at the Federal University of Sergipe. The first study aimed the reading time, into Portuguese and English languages, in a silent reading, and reading aloud, and the control of eye movement (the amount and the duration of fixation and go-past reading time) with three experimental groups in order to identify the effects of the aging in the participants. According to Cozijn; Vonker (2003), Rayner (2007), Dehaene (2012), the stablished standard for young speed readers, with fixation between 200 and $250 \mathrm{~ms}$, that may get to $350 \mathrm{~ms}$; for other types of group readers as aging and elderly people, the variability may overdo $500 \mathrm{~ms}$ in both direct ways of reading (silent reading, reading aloud). The young participant group became different from the other groups, getting the standard of 200 to $250 \mathrm{~ms}$. The young group obtained a longer time in the English group than the Portuguese reading time. The elderly participant group showed a great number over the standard pattern of reading in $500 \mathrm{~ms}$, with the result of $600-650 \mathrm{~ms}$. In the English texts, the length time was over the standard one, between the three categories. The participants read the English texts in silent reading faster than the reading aloud texts. The second study aims to measure the planned and the executed length time of the extension course classes entitled "The English class for the aging people", with the purpose of identifying the demand of time. Each class was planned with the acting of the documental control, in timing every minute from $\mathrm{A} 1, \mathrm{~A} 2, \mathrm{~A} 3, \mathrm{~A} 4, \mathrm{~A} 5, \mathrm{~A} 6, \mathrm{~A} 7, \mathrm{~A} 8, \mathrm{~A} 9, \mathrm{~A} 10$. The total global executed length time in both languages was inferior for the planned classes. The outcome for group -1, was 136, $6 \mathrm{~min}$, with an average of 135, $2 \mathrm{~min}$ per class, the longer pedagogical activities that overdo were, A1, A2, A4, A7, A10. For group 2 the planned and the executed length time, the outcome was 116, 6 min for each class, with a longer length time for the activities A5, A6, A8. Considering the aims of the groups, the longer time difference is related for the social activities (emotional assessment and coffee break), for the pedagogical activities, the students demand longer time for the previous class reviews, word building, and extra activities which overdo the directed length time. In group 2, the activities that overdo the length time were direct for the silent reading and reading aloud, review the previous class, and discuss about both language culture. The third study, aimed to measure the emotional reactions of the aging participants, as well as elderly ones about the extension course "The English class for the aging people", to verify the effects of the social time. Emotional test assessments were applied, in the beginning and at the end of the classes, with adjective words (time for learning) of course; to measure the satisfaction level on the participants of the English classes and analyze the reaction that the course motivates on the participants. The general outcomes show that although the aging studies demand a longer time for the executive functions, this demanding is not a hindrance for the participation in an English course. Our empiric study, with the analyses of reading time, eye-tracking, planning class length time, and emotional assessment charts contribute for the refining of the English course, with punctual outcome, that may be of use, for the implementation of the curricula components, pedagogical procedures for the adapted and evaluation of the printed and digital materials, as well as graduation course, and continuity studies, for the formation of the new teachers to be capable for a new workforce, as the aging and elderly people.
\end{abstract}

Keywords: Aging people. Elderly people. English. Reading time. Motivation. 


\section{RESUMEN}

En el año 2025, Brasil será considerado el quinto mayor país del mundo en número de ancianos, según proyecciones del Instituto Brasileño Geográfico y Estadística (IBGE) y, ante ese impacto demográfico, demandas por estudios en las áreas socioeconómica, salud y educación empiezan a surgir. Las políticas implementadas en el país, como la Ley n ${ }^{\circ} 10.741$ / 2003, Estatuto del Anciano, apuntan a la integración social de los longevos, pudiendo contribuir con la calidad de vida, como es el caso de aprender una nueva lengua. Elegimos para esta tesis verificar el efecto del tiempo, en sus dimensiones social y cognitiva, en las clases de inglés para el público longevo: envejecientes y personas de tercera edad. La dimensión social se refiere al cambio en los patrones sociales de la conciencia sobre el envejecimiento y expectativas y motivaciones en relación a la escolarización y al mercado de trabajo que interfieren en el proceso de enseñanza-aprendizaje de una lengua extranjera. La dimensión del tiempo cognitivo que influye en el aprendizaje de una lengua implica la relación con el lenguaje, en términos de fisiología y de sus procesos. Para medir los efectos del tiempo social y del tiempo cognitivo en las clases de inglés, realizamos, en esta tesis, tres estudios, a partir de datos recogidos en clases de dos grupos de un curso de extensión, "La clase de inglés para la tercera edad", en el primer semestre de 2016, en la Universidad Federal de Sergipe. El primer estudio tuvo como objetivo medir el tiempo de lectura, en portugués y en inglés, de modo silencioso y en voz alta, y el control del movimiento ocular (cantidad y duración de las fijaciones y regresiones), con tres grupos experimentales, a fin de identificar los efectos del envejecimiento en los participantes. Según Cozijn y Vonker (2003), Rayner (2007), Dehaene (2012), el patrón establecido es que jóvenes lectores hábiles leen más rápido, en 200 a $250 \mathrm{~ms}$, y pueden llegar a $350 \mathrm{~ms}$; para otros tipos de lectores, como envejecientes y personas de la tercera edad, la variabilidad puede pasar de $500 \mathrm{~ms}$ en las dos vías directas de lectura (silenciosa y voz alta). El grupo de participantes jóvenes se diferenció de los otros dos grupos, obteniendo el patrón de 200 a $250 \mathrm{~ms}$. El grupo joven obtuvo un tiempo mayor que en la lectura en portugués. Los participantes de la tercera edad presentaron un número mucho mayor establecido al marco de lectura de 500ms, presentando un valor de $600-650 \mathrm{~ms}$. En los textos de inglés, el tiempo fue mayor entre las tres categorías. Los participantes leyeron los textos en inglés y en voz silenciosa más rápido que los textos en voz alta. El segundo estudio pretende medir el tiempo de planificación y de ejecución de las clases del curso de extensión "La clase de inglés para la tercera edad", a fin de identificar la demanda de tiempo. Se planificó y documentó cada una de las clases con el control de tiempo de ejecución de cada una de las tareas A1, A2, A3, A4, A5, A6, A7, A8, A8, A9, A10, A10. El tiempo global de ejecución en ambos grupos fue inferior al tiempo planificado. En la clase 1, el tiempo ejecutado fue de 136,6 min, presentando un promedio de 135,2 min por clase, cuyas actividades pedagógicas que duraron más tiempo fueron las tareas A1, A2, A4, A7 y A10. Para el grupo 2, el tiempo de las clases planificadas y ejecutadas resultó en un promedio de 116,6 min de clase, con mayor tiempo las actividades A5, A6 y A8. Considerando los objetivos de los grupos, la diferencia de tiempo mayor está relacionada en las actividades sociales (test emocional y coffee break). Para las actividades pedagógicas, los alumnos demandan más tiempo para la verificación de las clases anteriores, explicación de vocabulario y actividades extras. En el grupo 2, las actividades que demarcaron más tiempo se direccionaron para lectura en voz alta y silenciosa, revisar las estructuras de la lengua y discusión de culturas de las lenguas. El tercer estudio tuvo como objetivo evaluar las reacciones emocionales de los participantes envejecientes y de la tercera edad del curso de extensión "La clase de inglés para la tercera edad", a fin de verificar los efectos del tiempo social. Se aplicaron testes emocionales de entrada y salida con palabras adjetivas (momento de aprendizaje) de dicho curso, para medir el grado de satisfacción en participar de las clases de inglés y analizar las reacciones que el curso motiva en sus participantes. Los resultados globales apuntan que, aunque los estudios del envejecimiento demuestran que hay una demanda de tiempo mayor en la ejecución de tareas, esta demanda no es un obstáculo para la participación en un curso de lengua extranjera. Nuestro estudio empírico, con el análisis del tiempo de lectura y movimiento ocular, tiempo de planificación y las fichas emocionales, contribuye al perfeccionamiento de cursos de inglés, con resultados puntuales que pueden ser aprovechados para la implementación de componentes curriculares, con definiciones de contenido y procedimientos pedagógicos, preparación, adaptación y evaluación de material impreso y digital, y cursos de formación de profesores, inicial y continuada, para capacitarles a profesionales para actuar en un nuevo mercado de trabajo, como es el caso de los envejecientes y personas de tercera edad.

Palabras clave: Envejecimiento. Tercera edad. Inglés. Tiempo de lectura. Motivación. 


\section{LISTA DE FIGURAS}

Figura 1: Material didático adotado no curso de extensão $-1^{\circ}$ e $2^{\circ}$ períodos. ..................................................55

Figura 2: Material didático adotado no curso de extensão $-3^{\circ}$ e $4^{\circ}$ períodos. .....................................................56

Figura 3: Material didático adotado no curso de extensão $-5^{\mathrm{O}}$ período. ............................................................57

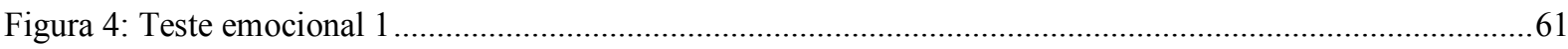

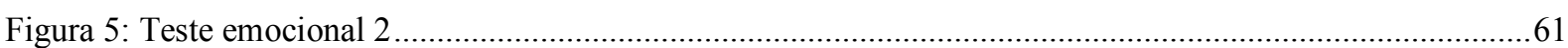

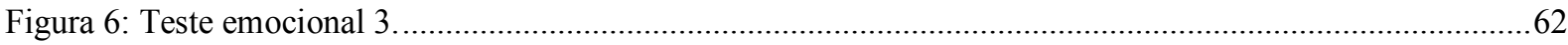

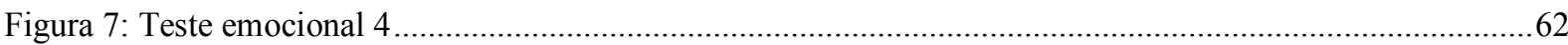

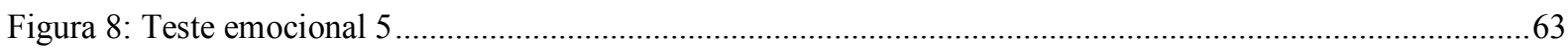

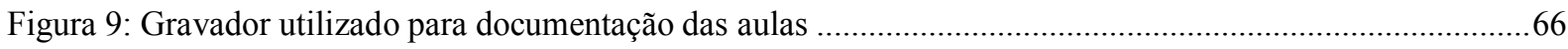

Figura 10: Posicionamento do participante durante calibragem e experimento com eye-tracker ........................67

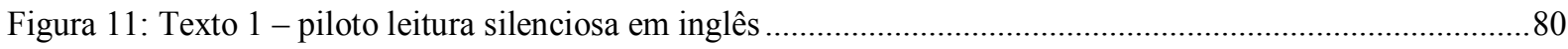

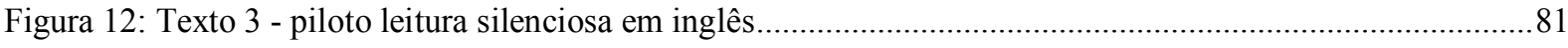

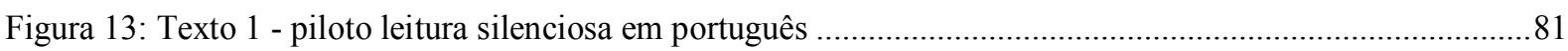

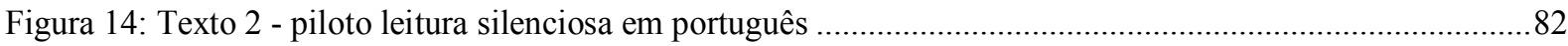




\section{LISTA DE GRÁFICOS}

Gráfico 1: Progressão da população brasileira 2000-2025. .19

Gráfico 2: Distribuição das matrículas por faixa etária na educação superior nos anos de 2014 e 2015.

Gráfico 3: Desempenho dos grupos experimentais quanto ao tempo de leitura em voz alta e silenciosa, em textos em (A) português e em (B) inglês. .72

Gráfico 4: Desempenho dos grupos experimentais quanto ao número de fixações, em textos em (A) português e em (B) inglês. .75

Gráfico 5: Desempenho dos grupos experimentais quanto à duração média das fixações, em textos em (A)

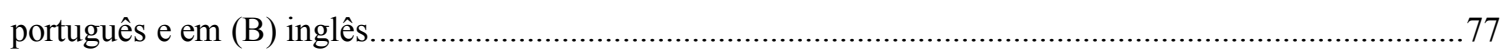

Gráfico 6: Número de regressões em função dos grupos experimentais: (A) português e em (B) inglês ..............83

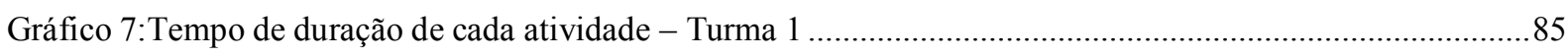

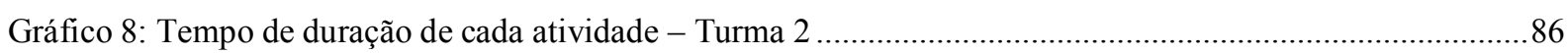

Gráfico 9: Testes emocionais dos participantes da terceira idade - Turma 1 (seg/qua) ....................................89

Gráfico 10: Testes emocionais dos participantes envellhescentes - Turma 1 (seg/qua) ...................................89

Gráfico 11: Testes emocionais dos participantes da terceira idade - Turma 2 (sex) .......................................90 


\section{LISTA DE QUADROS}

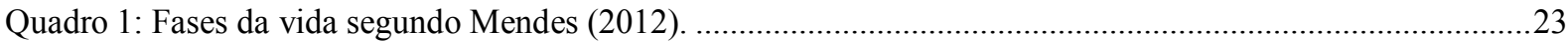

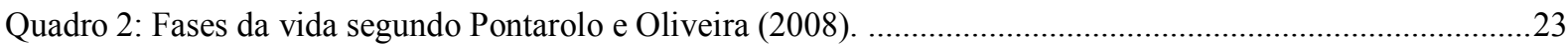

Quadro 3: Fases da vida segundo Silva (2015)............................................................................................24

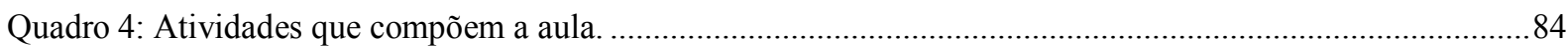




\section{SUMÁRIO}

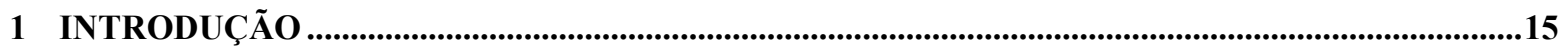

2 TEMPO SOCIAL E TEMPO COGNITIVO NO ENVELHECIMENTO ...............................................19

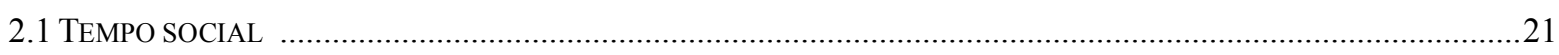

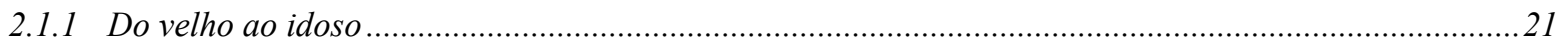

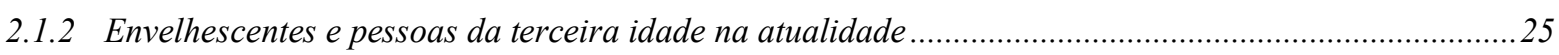

2.1.3 Envelhescentes e pessoas da terceira idade em busca de conhecimento ………………………….........28

2.1.4 Politicas públicas para envelhescência e terceira idade ................................................................

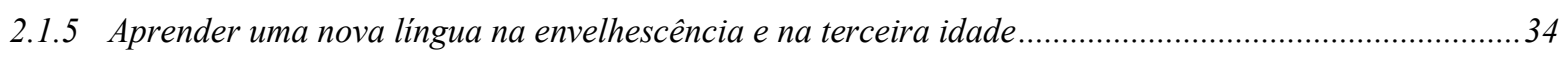

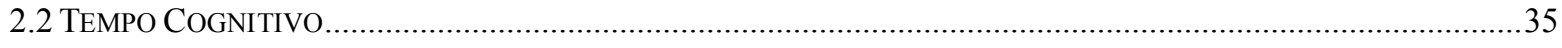

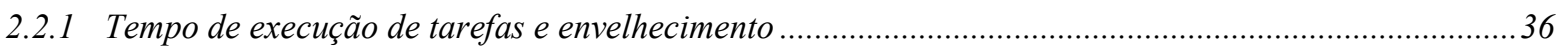

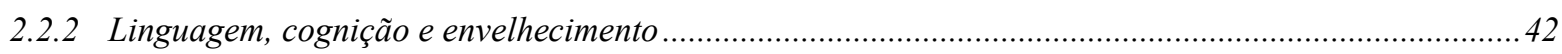

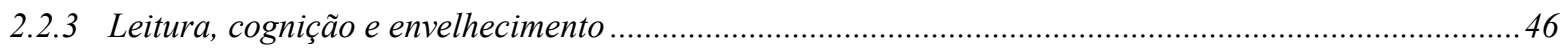

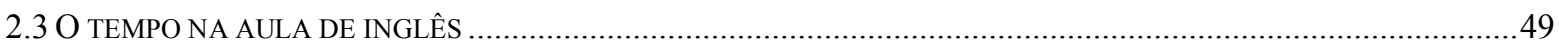

\section{ESTUDO SOBRE O ENSINO DE INGLÊS PARA ENVELHESCENTES E PESSOAS DE}

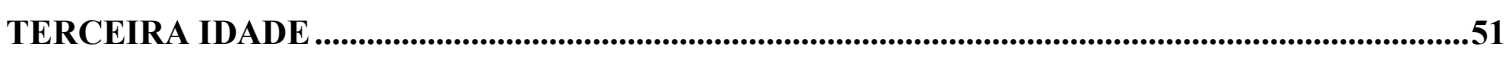

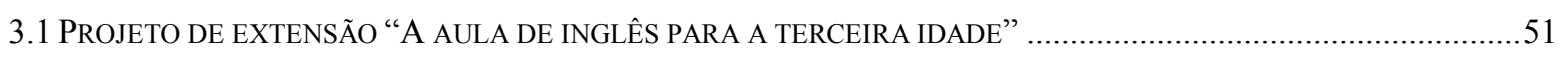

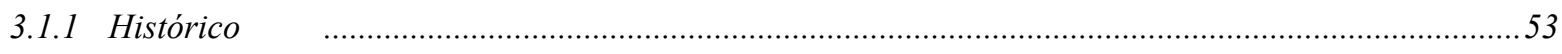

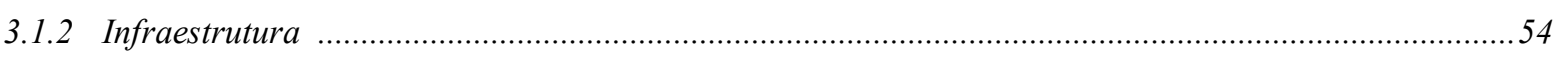

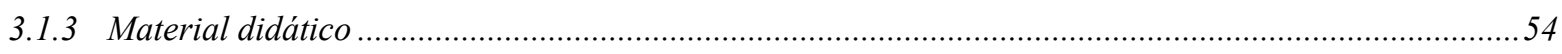

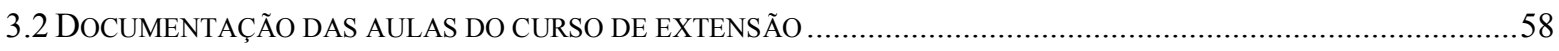

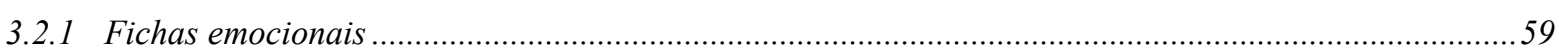

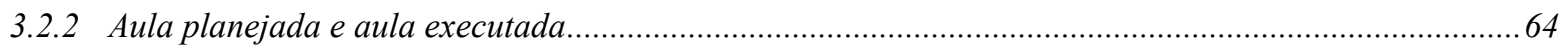

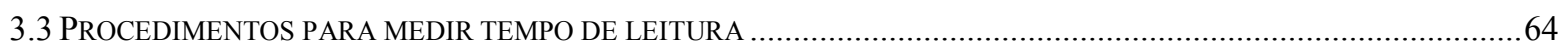

4 TEMPO DE LEITURA, TEMPO DE AULA E MOTIVAÇÃO........................................................70

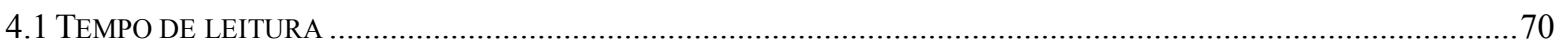

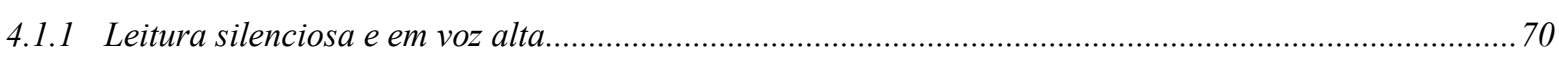

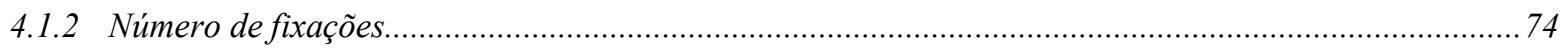

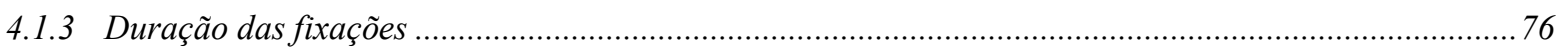

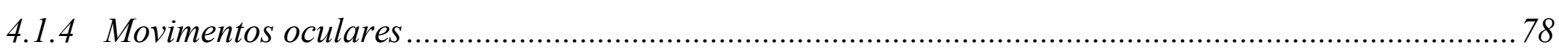

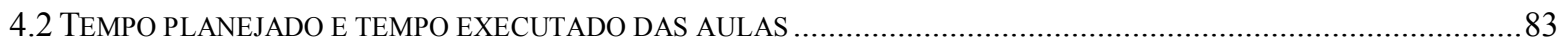

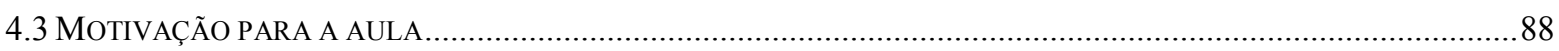

5 TEMPO SOCIAL E TEMPO COGNITIVO NA FORMAÇÃO DE PROFESSORES DE INGLÊS PARA A ENVELHESCÊNCIA E TERCEIRA IDADE ....................................................................92 
6 CONSIDERAÇÕES FINAIS...................................................................................................................95

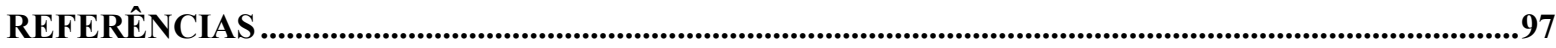

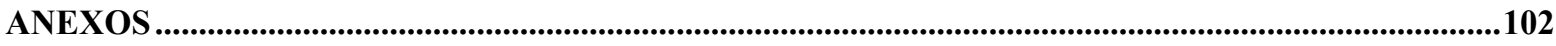

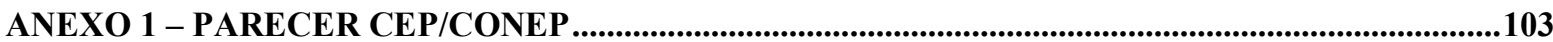

ANEXO 2 - MAPA DE POSICIONAMENTO EM CLASSE ...................................................................107

ANEXO 3 - FICHAS EMOCIONAIS.............................................................................................................108

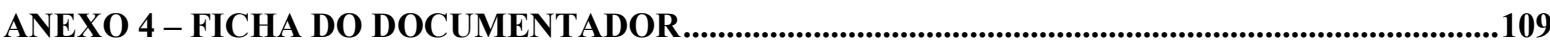

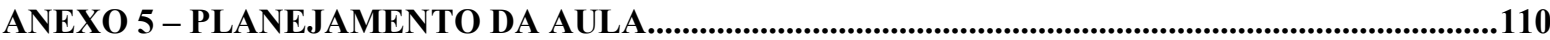

ANEXO 6 - ESTÍMULOS DO TESTE DE LEITURA..............................................................................112 


\section{INTRODUÇÃO}

Os efeitos do envelhecimento da população já vêm sendo observados em todo o mundo, inclusive no Brasil. A mudança da composição demográfica brasileira vai alterar profundamente as relações educacionais. Em 2025, segundo as previsões do Instituto Brasileiro Geográfico e Estatística (IBGE), haverá mais idosos do que crianças. Isso significa que os cursos de formação de professores precisam se preparar para um novo nicho no mercado de trabalho: envelhescentes e terceira idade. Por isso o foco desta tese se volta para o ensino de inglês para envelhescentes e terceira idade. ${ }^{1}$ Assim, ante a longevidade da população, políticas públicas precisam garantir qualidade de vida a esse grupo de pessoas. Para qualidade de vida, adotamos o conceito do Grupo de Qualidade de Vida da Organização Mundial de Saúde (World Health Organization Quality of Life Group), segundo o qual a qualidade de vida se refere à percepção do indivíduo em relação a sua posição na vida, no contexto da cultura e no sistema de valores em que vive, bem como a seus objetivos, expectativas, padrões e preocupações (THE WHOQOL GROUP, 1998). Os envelhescentes e pessoas da terceira idade de hoje desejam ressignificar suas vidas, com atividades diferentes, dentre elas o aprendizado de uma língua estrangeira, como o inglês.

O interesse por essa problemática nasceu em decorrência da demanda de interessados em aprender o inglês. No início da minha carreira acadêmico-profissional na Universidade Federal de Sergipe, em 1993, professores da instituição, desejosos por aprender a língua inglesa, bem como técnicos da instituição e pessoas da comunidade, procuravam o Departamento de Letras (DLE), assim chamado na ocasião, em busca de cursos de formação.

Na época, existia, no DLE, o Núcleo de Cultura Anglo Americano (Nucam), cujo objetivo era oferecer cursos paralelos aos alunos do curso de Letras Português/Inglês. Oferecia, também, um horário específico para os alunos da terceira idade da comunidade, antes mesmo

\footnotetext{
${ }^{1}$ Adotamos, para o escopo deste trabalho, a terminologia "envelhescente" (com SC, assim como nascer, crescer), que corresponde à pessoa entre as faixas etárias de 45 a 59 anos. Ao utilizarmos a palavra envelhescente, assumimos a postura de Mendes (2012), que inicialmente identificou o emprego da palavra para aquelas pessoas que estavam abertas a novos aprendizados. E assim nos reportaremos a esta palavra no nosso estudo. Quando tratarmos do tempo social, detalharemos melhor o conceito.
} 
da existência dos dispositivos da legislação vigente que versa sobre o direito de acesso à educação da terceira idade (Estatuto do Idoso). ${ }^{2}$

Contudo, por conta de limitações fisiológicas e cognitivas decorrentes do processo natural do envelhecimento, bem como por suas expectativas e objetivos serem diferentes, em função de sua vivência, os envelhescentes e pessoas da terceira idade necessitam de uma abordagem pedagógica diferente da que é dada, por exemplo, a alunos sem distorção série/idade na educação básica. Por isso é necessário um compromisso especial com o ensino voltado para esse tipo de público.

Atualmente, o Nucam não está mais ativo, mas os princípios que o norteavam persistem por meio da oferta do curso de extensão “Aula de Inglês para a Terceira Idade”, fomentado pela Pró-Reitoria de Extensão (Proex), via Programa Institucional de Iniciação à Extensão (Pibix).

O compromisso de atender aos envelhescentes e pessoas da terceira idade existente desde o meu ingresso como professora na UFS se fortaleceu ainda mais ao entrar no doutorado em Educação na mesma instituição, quando passei a investigar se, para o ensino de inglês voltado para pessoas da terceira idade, era necessário o uso de estratégias especiais de ensino. Assim, com esta tese, quero contribuir para a formação de profissionais de língua inglesa para atuarem com o público-alvo em questão, atendendo às novas demandas de mercado de trabalho.

No Departamento de Letras Estrangeiras (DLES), o currículo vigente do curso de licenciatura em Letras/Inglês ainda não contempla disciplinas para a formação de professores de língua inglesa para atuarem com esse público específico. Por isso esta tese tem como objetivo defender que é necessária a formulação de políticas públicas que se voltem para o fomento de uma formação profissional particularizada e habilitada a atender a essa clientela.

É importante destacar que esta tese foi contemplada com auxílio financeiro do edital FAPITEC/SE/FUNTEC/CAPES N 07/2015 - NAPS LINHA 2. Esse edital teve como objetivo apoiar propostas que visassem a subsidiar a formulação, a avaliação e a orientação de políticas públicas em linhas temáticas específicas de interesse prioritário para entidades da Administração Pública do Estado de Sergipe. O alinhamento a essa chamada é decorrente de sua contribuição para a formação acadêmica de futuros professores matriculados no curso de

\footnotetext{
${ }^{2}$ O espaço do Nucam foi desativado, em 2006, para abrigar o Núcleo de Pós-Graduação em Letras, sempre com a promessa de que haveria espaço para que fosse novamente reativado, mas até hoje isso não se concretizou na instituição.
} 
Letras Inglês da Universidade Federal de Sergipe que se disponham a participar do projeto com vistas a lidar com o público da envelhescência e terceira idade.

O recorte que damos neste trabalho é o tempo em suas dimensões social e cognitiva. A dimensão social do tempo é entendida como a mudança nos padrões sociais relacionadas à consciência sobre o envelhecimento. Isso pode ser observado, por exemplo, nas diferenças de expectativas entre uma pessoa da terceira idade dos dias atuais e outra de tempos mais remotos. No passado, pessoas da terceira idade deixavam de ter uma vida social, ficando mais em casa, cuidando dos netos, ajudando as famílias, e se anulavam com relação a sua própria identidade. Hoje, esse comportamento é menos comum. As pessoas da terceira idade desejam viver de forma diferente, fazendo coisas que nunca tiveram a oportunidade de fazer. Essas mudanças de comportamento levam a mudanças das expectativas e das motivações em relação à escolarização e ao mercado de trabalho. Essa mudança de percepção, pode, inclusive, alterar os rótulos associados a esse público, que passa a aumentar sua autoestima e motivar-se para aprender uma língua estrangeira.

A dimensão cognitiva, por sua vez, depende de processos fisiológicos, que, por conta do processo natural do envelhecimento, são afetados. Assim, atividades mentais, como ver, entender, lembrar e resolver problemas são afetados pelas degenerações causadas pela chegada da idade. Nesse sentido, o tempo cognitivo envolve a relação com a linguagem e está ligada a processos fisiológicos que influenciam o aprendizado de uma língua. Para medir os efeitos do tempo social e do tempo cognitivo nas aulas de inglês, realizamos, para esta tese, três estudos: tempo de leitura, fixações e regressões; tempo de planejamento e execução das aulas; e testes emocionais. Como não existem turmas de alunos regulares na faixa etária da envelhescência e da terceira idade na educação básica nem na educação superior, utilizamos como lócus dos estudos o curso de extensão "A aula de inglês para a terceira idade", que foi por mim coordenado, e executado por alunos do curso de Licenciatura em Inglês. Dado o objetivo geral da tese, já apresentado, os objetivos específicos foram:

- Revisar os aspectos do tempo social e do tempo cognitivo potencialmente relevantes no processo de ensino-aprendizagem de uma língua estrangeira;

- Medir o tempo de leitura, em português e em inglês, de modo silencioso e em voz alta, e o controle do movimento ocular (quantidade e duração das fixações e regressões), com três grupos experimentais (jovens, envelhescentes, pessoas da terceira idade) a fim de identificar os efeitos do envelhecimento nos participantes. 
- Aferir o tempo de planejamento e de execução das aulas do curso de extensão "A aula de inglês para a terceira idade" a fim de identificar a demanda de tempo.

- Controlar as reações emocionais dos participantes envelhescentes e pessoas da terceira idade do curso de extensão "A aula de inglês para a terceira idade" a fim de verificar os efeitos do tempo social.

- Sistematizar os resultados dos estudos desenvolvidos como contribuição para programas de ensino visando à formação de professores de inglês para atuarem com esse público.

Além desta introdução e das considerações finais, esta tese está estruturada em mais quatro seções. Na seção dois, são apresentados os conceitos de tempo social e de tempo cognitivo e sua relação com o ensino de uma língua estrangeira. A seção 3, além de apresentar o desenho dos estudos desenvolvidos, faz um retrospecto do curso de extensão "A aula de inglês para a terceira idade", que serviu de lócus para a pesquisa desta tese. A seção 4 apresenta detalhadamente os resultados dos estudos: tempo de leitura, fixações e regressões; tempo de planejamento e execução das aulas; e testes emocionais. A seção 5 sumariza os resultados dos estudos desenvolvidos e tece relações com a prática pedagógica. Esperamos que a leitura desta tese contribua não só para reflexões sobre o envelhecimento e suas relações com o processo ensino-aprendizagem no espaço escolar, mas também para a tomada de consciência de que todos nós vamos envelhecer e que precisamos ter qualidade de vida. $\mathrm{O}$ estudo de inglês pode ajudar! 


\section{TEMPO SOCIAL E TEMPO COGNITIVO NO ENVELHECIMENTO}

A partir do que apontam os dados do Censo 2010 do Instituto Brasileiro de Geografia e Estatística (IBGE), no ano 2025, a população de idosos do Brasil será superior a $16 \%$, o que colocará o Brasil em quinto lugar no ranking mundial de países com maior população de idosos ${ }^{3}$. Segundo as estimativas do IBGE, em 2060, o Brasil passará a ter 58,4 milhões de idosos, correspondendo a $26,7 \%$ do total da população. O país contabiliza hoje mais de 3,5 milhões de idosos com idade superior a 80 anos. Em 2060, esse público será de 19 milhões, o que corresponde a um crescimento equivalente a 27 vezes em relação a 1980, quando o país possuía menos de 1 milhão de pessoas nessa faixa etária: 684.789 pessoas (IBGE, 2010).

Gráfico 1: Progressão da população brasileira 2000-2025.

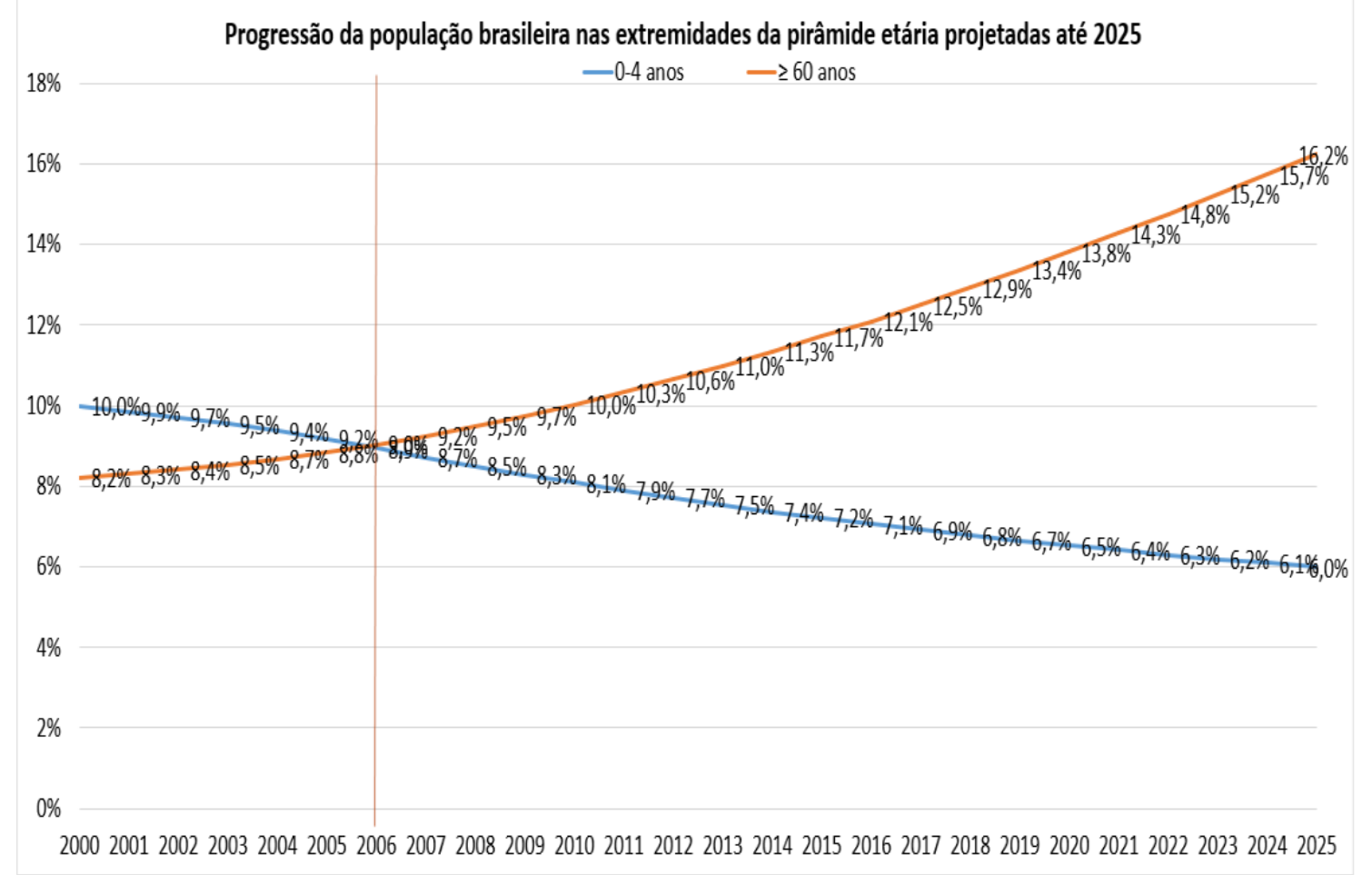

A situação brasileira na relação com o fenômeno do envelhecimento convive, passo a passo, com a realidade de um país ainda considerado jovem. A inversão da pirâmide populacional pega de surpresa toda uma estrutura socioeconômica e política que, sequer, é habilitada a atender as questões das outras faixas

\footnotetext{
${ }^{3}$ De acordo com a legislação vigente, e adotada nas previsões do IBGE, considera-se idoso a pessoa de 60 anos de idade.
} 
etárias, muito embora a enfrentar as demandas de um fenômeno social chamada "velhice ou envelhecimento populacional. (SILVA, 2016, p. 113)

Faz-se necessário, então, pensar em estratégias que garantam uma melhor qualidade de vida ao brasileiro, cuja expectativa de vida passará de 75 anos para 81 anos de idade, segundo projeção do IBGE. Nossa proposta de ensino de inglês visa a contribuir para a qualidade de vida desse público. Para isso, precisamos lidar com a noção de tempo que está presente no processo de envelhecimento.

$\mathrm{Na}$ cultura ocidental, tempo está associado à sucessão dos anos, dias, horas. $\mathrm{O}$ quantitativo de anos vividos por uma pessoa faz com que se insira numa determinada fase da vida: criança, adolescente, adulto, envelhescente, terceira idade.

As mudanças que se processam na pessoa no decorrer da passagem do tempo, não estão associadas apenas a aspectos biológicos. Condições socioeconômicas podem, por exemplo, favorecer o retardamento ou adiantamento dos traços de sua aparência, sendo esse processo gradativo para uns e mais rápido para outros, a depender de sua forma de vida. No plano biológico, as mudanças decorrem de transformações fisiológicas. Assim, com a chegada da idade, surgem carência de acuidade visual, cabelos grisalhos, ritmo de marcha mais lenta, etc. Esses aspectos interferem psiquicamente nas dimensões cognitiva, psicológica e social do idoso (CAETANO, 2006).

Como o aprendizado de uma língua estrangeira interfere na percepção e nas emoções das pessoas, vamos, nesta tese, lidar com duas dimensões do tempo, que estão relacionadas ao processo do envelhecimento e que podem interferir no processo de ensino-aprendizagem de uma língua, no nosso caso, o inglês: o tempo cognitivo e o tempo social. Por tempo cognitivo, estamos entendendo as relações estabelecidas pela cognição e sua demanda de tempo, a exemplo do tempo de processamento da leitura e do tempo de execução de um exercício ou de uma atividade. Como, com o envelhecimento, chegam as perdas cognitivas, objetivamos identificar qual a interferência dessas perdas no processo de ensino-aprendizagem de uma outra língua. Isso contribuirá para a formação de professores que desejem atuar com o público formado de envelhescentes e pessoas da terceira idade.

O tempo pode também estar relacionado ao momento ou ocasião apropriada para a realização de uma ação (o tempo da aposentadoria, o tempo de um novo aprendizado), o que caracteriza o que chamamos de tempo social. Em um curso de língua inglesa para o público de envelhescentes e pessoas da terceira idade, os efeitos do tempo social são diferentes do que seria para alunos regulares da educação básica: motivações para a 
aprendizagem de uma língua estrangeira, como a língua inglesa, ou o estado emocional durante as aulas não são os mesmos.

Assim, este capítulo visa a apresentar aspectos do tempo social e do tempo cognitivo no envelhecimento que precisam ser considerados no ensino de uma língua estrangeira.

\subsection{TEMPO SOCIAL}

A consciência sobre o envelhecimento muda padrões sociais. No passado, pessoas da terceira idade deixavam de ter uma vida social, ficando mais em casa, cuidando dos netos, ajudando as famílias, e se anulavam com relação à sua própria identidade. Hoje, já não vemos mais esse comportamento de maneira tão generalizada. As pessoas da terceira idade desejam viver de forma diferente, fazendo coisas diferentes que nunca tiveram a oportunidade de fazer. Essas mudanças de comportamento levam a mudanças nos rótulos associados a esse público. Expectativas e motivações em relação à escolarização e ao mercado de trabalho podem interferir no processo de ensino-aprendizagem de uma língua estrangeira.

\subsubsection{Do velho ao idoso ${ }^{4}$}

O ciclo da vida do ser humanos costuma ser dividido em quatro etapas ou fases: infância, adolescência, adultez e velhice ou terceira idade. A Organização Mundial da Saúde (OMS) vem considerando a idade de 60 anos como o início da terceira idade. Do ponto de vista biológico, essa idade corresponde à fase da vida em que traços de senilidade começam a ficar aparentes (HADDAD, 1997).

Adotado recentemente no Brasil, o termo "terceira idade" foi trazido por gerontologistas que se formaram na França (DEBERT, 1994). Segundo Haddad (1986), a designação "terceira idade", inicialmente, foi utilizada pelo gerontologista francês Heut, que a conceituou como a fase mais madura da vida que se inicia próximo à idade da aposentadoria. Contudo, a faixa de idade que compreende a terceira idade (troisième áge) não é ponto pacífico entre os estudiosos: o assunto tem sido bastante discutido por psicólogos, geriatras, gerontologistas, educadores e sociólogos.

\footnotetext{
4 “Do Velho ao idoso" é o título do livro de Costa Lima (2014), que inspira esta seção.
} 
O uso de palavras para se referir às fases da vida é modificado com o passar do tempo e com as mudanças da sociedade. Velho, idoso, envelhescente, melhor idade, maior idade, terceira idade são termos que costumam ser utilizados para se referir a mesma fase da vida. Diversos autores se preocuparam com essa questão. Mendes (2012), até início dos anos 1990, categorizava as fases da vida humana em infância (até 11 anos), adolescência (dos 12 aos 19 anos), idade adulta (dos 20 aos 59 anos) e velhice (a partir dos 60 anos). Ao reconhecer que o envelhecimento é um processo contínuo, pesquisadores, particularmente da área da psicologia, mais precisamente da psicanálise, foram constituindo uma nova categoria: a envelhescência. Essa fase vai dos 45 aos 59 anos, entretanto, por essa demarcação cronológica não poder ser estanque e precisa, pode perdurar por mais tempo. Prata (2007) caracteriza a envelhescência como

\begin{abstract}
uma preparação para entrar na velhice, assim como a adolescência é uma preparação para a maturidade. Engana-se quem acha que o homem maduro fica velho de repente, assim da noite para o dia. Não. Antes, há envelhescência. E, se você está em plena envelhescência, já notou como ela é parecida com a adolescência. Coloque os óculos e veja como este nosso estágio é maravilhoso: [...] Os adolescentes mudam a voz. Nós envelhescentes, também. Mudamos o nosso ritmo de falar, o nosso timbre. [...] Ninguém entende os adolescentes...Ninguém entende os envelhescentes... Ambos são irritadiços, se enervam com pouco. Acham que já sabem de tudo e não querem palpites nas suas vidas. [...] Os adolescentes não entendem os adultos e acham que ninguém os entende. Nós envelhescentes também não entendemos eles. Ninguém me entende é uma frase típica de envelhescentes. [...] O adolescente ama assistir a um show de um artista envelhescente (Caetano, Chico, Mick Jagger). O envelhescente ama assistir a um show de um artista adolescente [...] Daqui a alguns anos, quando insistirmos em não sair da envelhescência para entrar na velhice, vão dizer: - É um eterno envelhescente! (PRATA, 2007, p. 60-61)
\end{abstract}

Conforme Mendes (2012), o termo envelhescente é empregado para aquelas pessoas que estão abertos a novos aprendizados, conceito com o qual concordamos e o adotamos nesta tese. Enquanto a envelhescência abrange as idades de 45 aos 59 anos, a terceira idade é a etapa da vida que começa aos 60. Entretanto, essa não é uma classificação consensual, principalmente quando são levados em conta aspectos sociais e de desenvolvimento humano.

Para Mendes (2012), as fases da vida são 5, conforme apresentado no quadro 1: 
Quadro 1: Fases da vida segundo Mendes (2012)

Infância (0-11 anos)

Adolescência (12-19 anos)

Adoleduto (20-30 anos)

Adulto (31-44 anos)

Envelhescente (45-59 anos)

Terceira idade (+ 60 anos)
Fase inicial da educação e instrução. A criança inicia o processo de saber se comportar entre as várias categorias da sociedade.

Fase das descobertas e sentido da vida escolar e início na participação da sociedade.

Fase da idade da força de trabalho, etapa vital de dedicação ao trabalho.

Fase de idade posterior à adolescência, fase de transição.

Fase de preparação para o sujeito entrar na maturidade, ou velhice.

Fase que pode delongar mais tempo, por não existir uma cronologia precisa.

Mendes (2012, p. 59) aponta a predisposição para a discriminação ao se usarem as terminologias "idoso" (ido: aquele que já foi?) e "velho" (fora de prazo de validade?), bem como "terceira e melhor idade", por parte de pessoas envelhescentes, por não aceitarem estar incluídos nessa categoria.

Já Pontarolo e Oliveira (2008), ao considerar os efeitos da longevidade na população, apresentam uma classificação das fases da vida mais ampliada em relação à proposta por Mendes (2012), conforme sistematizado no quadro 2:

Quadro 2: Fases da vida, segundo Pontarolo e Oliveira (2008)

Fase inicial da educação e instrução. A

Primeira idade (0-20 anos) criança inicia o processo de saber se comportar entre as várias categorias da sociedade.

Segunda idade (21-49 anos)

Terceira idade (50-77 anos)

Quarta idade (78-105 anos)
Fase da idade da força de trabalho, etapa vital de dedicação ao trabalho.

Fase de preparação para o sujeito entrar na maturidade, ou velhice.

Fase que pode delongar mais tempo. A longevidade será favorecida aos sujeitos que souberem adquirir manutenção pessoal.

Silva (2015) afirma não existir como determinar a idade específica para definir que uma pessoa está na terceira idade. Afirma ainda que, para alguns autores, a terceira idade começa a partir de 60 anos; para outros, a partir de 55 anos. Silva (2015) destaca 
que já se ensaia a referência a uma quinta idade, iniciada a partir dos 85 anos, conforme quadro 3:

Quadro 3: Fases da vida segundo Silva (2015)

Primeira idade (0-20 anos)

Segunda idade (21-54 anos)

Terceira idade (a partir dos 55-60 anos)

Quarta idade (61-84 anos)

Quinta idade (a partir dos 85 anos)
Fase inicial da educação e instrução. A criança inicia o processo de saber se comportar entre as várias categorias da sociedade.

Fase da idade da força de trabalho, etapa vital de dedicação ao trabalho.

Fase da terceira idade, a partir de 55 ou 60 anos.

Fase da idade da maturidade e preparação para a longevidade.

Fase que pode delongar mais tempo. A longevidade será favorecida aos sujeitos que souberem adquirir manutenção pessoal.

Na proposta de fases da vida, vale ressaltar que a comparação entre juventude e velhice serve apenas para reconhecer características próprias de determinada fase, uma vez que o envelhecimento não é igual para todos e, a depender de características genéticas, culturais e sociais, pode haver algum declínio cognitivo (SANTOS; ROSSETTI; ORTEGA, 2006). Como pudemos observar, não há uma padronização etária para definir se a pessoa é idosa. Considerando a faixa etária, pode ir dos 45 aos 65 anos. Entretanto, aspectos socioculturais podem variar de pessoa para pessoa e isso interfere no estilo de vida, o que permite o surgimento de "estereótipos positivos" como o idoso jovem, o idoso produtivo, o idoso culto e participativo socialmente.

No século XIX, o velho foi condenado ao ostracismo social. O estereótipo de improdutivo o colocava a parte de pessoas de outras faixas etárias. Requeria-se, então, que houvesse o seu amparo por parte da previdência. Já no século XX, o velho foi redefinido socialmente como sujeito da terceira idade, definição essa que permanece até os dias atuais: "o velho, em meio a esses fenômenos sócio-históricos, transformou-se em idoso, um tipo de categorização dos indivíduos de mais idade mais adequada para o sistema social e cultural vigente" (COSTA LIMA, 2014, p. 43).

De acordo com Peixoto (1998), o conceito de idoso foi utilizado para pessoas que viessem a atingir a idade de 60 anos por serem mais "sérios" em sua aparência, enquanto que terceira idade era utilizada para "jovens velhos", aqueles que eram dinâmicos, com uma aparência extrovertida, fácil de interagir com outros grupos. Ainda segundo Peixoto (1998), o idoso simboliza os "velhos respeitados", enquanto terceira idade, os jovens 
velhos aposentados, dinâmicos, capazes de passar por uma nova etapa da vida. Já Neri e Freire (2000) consideram que a palavra velho ou idoso designa pessoas idosas, que estão na velhice, que estão na última fase do ciclo da vida.

Como vimos, inúmeras são as denominações para as faixas etárias que começam a partir da envelhescência, não sendo necessário se prender a uma idade específica que caracterize a terceira idade ou a velhice. Cabe a cada um decidir que denominação ou conceito utilizar. O que importa é respeitar o padrão e limites individuais para vencer os desafios que chegam com a idade. No entanto, para este trabalho, precisamos estabelecer um recorte, a fim de viabilizar a implementação de uma metodologia. Assim, ainda que reconheçamos que o envelhecimento é um processo, sem necessariamente estar preso a uma faixa etária, consideramos "envelhescentes" as pessoas que estão na faixa etária de 45 a 60 anos e terceira idade as pessoas que ultrapassem os 60.

Independentemente da terminologia, nessa fase da vida, envelhescentes e pessoas da terceira idade desejam continuar ativos para manter o estado biológico em perfeita atividade a fim de ter uma boa saúde e de viver longevamente (NERI; FREIRE, 2000).

\subsubsection{Envelhescentes e pessoas da terceira idade na atualidade}

Do ponto de vista do tempo cronológico, leva-se muito tempo para se adquirir instrução e ocupação no mercado de trabalho sob as leis vigentes de cada época. O tempo social demonstra como o idoso do passado reagia à vida social, a exemplo de sua reclusão com a chegada da aposentadoria após longos anos de atividade no mercado de trabalho. Ele se restringia a viver em casa, com poucos amigos e pouco relacionamento familiar, diferentemente do idoso atual, que é consciente de que precisa se manter ativo socialmente e cognitivamente. Todo aquele que trabalha ao longo da vida não pode parar e simplesmente se excluir de uma vida social. Afinal, o homem é um ser que vive em sociedade.

Somos o produto de uma experiência de vida compartilhada com nossos familiares. A nossa identidade retrata no futuro o que fomos no passado, o que somos no presente e como pretendemos ser no futuro. Como vimos, no passado, pessoas da terceira idade modificavam sua maneira de viver. Deixavam de ter uma vida social, ficando mais em casa, cuidando dos netos, ajudando as famílias e se anulavam com relação a sua própria identidade. Hoje, essa atitude não é mais apreciada. Esse público deseja aprender

a viver de forma diferente, fazendo coisas diferentes que eles nunca tiveram a 
oportunidade de fazer. A consciência e a mídia ajudam a divulgar a importância de se viver uma nova vida com hábitos mais saudáveis do que eles levavam anteriormente. (MENDES, 2012)

As relações entre terceira idade e outras idades, na sociedade atual, têm sido discutidas no que diz respeito à terminologia idoso, a partir do que se criam estereótipos e crenças sobre como as pessoas se referem aos demais nessa fase da vida. Vieira e Lima (2015) mostram uma dicotomia que avalia positivamente quando tratados individualmente e negativamente quando estão em grupos, ou seja, em sociedade. Esses resultados mostram que as famílias ainda não se preparam para o envelhecimento, não só no que se refere às relações familiares, mas também no que se refere a uma vida futura saudável e suficiente economicamente. Não havendo esse planejamento, podem surgir problemas como declínio mental e ou fisiológico e perdas cognitivas no âmbito individual. No âmbito social, podem surgir o isolamento, a agressividade, etc.

Segundo Frange (2015), nas décadas de 1980 e 1990, já se pôde perceber uma mudança substancial, pois os "idosos" começaram a ser conclamados a adquirir valores mais modernos, como participação social, segurança, autoestima, tudo isso através da compra de utensílios e serviços bancários. Essa tendência de considerar os idosos como consumidores potenciais foi mantida na virada do milênio. Goldstein (1995) mostra que a maioria dos envelhescentes e pessoas da terceira idade apresentam opiniões positivas sobre a vida atual e as possibilidades do envelhecimento. Afirma ainda que "os adultos e terceira idade têm, em virtude das mudanças físicas, psicológicas e sociais comuns à sua faixa etária, maior possibilidade de enfrentar tipos de eventos diferentes daqueles enfrentados pelos mais jovens" (GOLDSTEIN, 1995, p. 239).

Os adultos de hoje já começam a se preocupar com a chegada da idade, procurando conhecer os impactos disso em si mesmos. Assim, é importante saber conduzir a forma de viver antes mesmo dos primeiros sinais de senilidade, como perda de visão e cabelos grisalhos. Existem vantagens e desvantagens no envelhecimento, o que requer estar atento a possíveis readaptações, não só fisiológicas, mas também sociais, por isso é preciso observar as disposições físicas e cognitivas e procurar ressignificar a vida, ocupando o cérebro com diversas atividades que lhes proporcione, senão prazer, ao menos, gosto pela vida.

A Europa e os Estados Unidos começaram a levantar questões sobre o conhecimento das transformações da expectativa de vida no Pós-Guerra. Debert (2004) apontou essa mudança como um problema social, uma vez que as pessoas da terceira 
idade reafirmavam novos modelos de vida na sociedade. Esse novo modelo de comportamento foi possível porque as pessoas dessa fase mantiveram a cognição e o exercício de sua autonomia para transitar nos espaços sociais, buscando novos aprendizados. No Brasil, segundo Debert (2004), o Serviço Social do Comércio (SESC) e a Legião Brasileira de Assistência (LBA) lançaram programas sociais voltados para as pessoas "idosas", promovendo atividades de lazer. Tais ações causaram um despertar nesse público para o conhecer, para o desafio de passar por novas experiências, por novos aprendizados.

A terceira idade, hoje, em sua maioria, busca ações voltadas para a área da educação, para novas formas de viver, reconstruindo uma nova rede de relações sociais (COSTA LIMA, 2014). A pessoa de mais idade, como vimos, é aquela que estava à procura de uma melhor qualidade de vida, valorizando o exercício da cidadania e o seu potencial produtivo, mesmo em uma nova faixa etária, buscando seu prazer e bem-estar individual, e, assim, melhorando a autoestima.

Pereira (2014) destaca a preocupação com a inserção social dos envelhescentes e das pessoas da terceira idade, considerando os interesses específicos desse universo heterogêneo por lazer, por ocupação do tempo livre e, acima de tudo, por qualidade de vida. Haddad (1997) evidencia que envelhescentes e pessoas da terceira idade se sentem mais saudáveis, de bem com a vida e de bom humor, quando se sentem ativos.

Se, no passado, envelhescentes e pessoas da terceira idade viviam em casa com tarefas domésticas para contribuir com a família, sem interesse de viver socialmente em instituições de educação, em restaurantes, em cinemas ou viajando, atualmente, esse grupo de pessoas diminuiu suas atividades domésticas e se motivaram para ir a locais públicos, para dar continuidade à vida pública, para (res)significar sua vida por meio de ações socioeducacionais e outras atividades, como viagens, aulas de pintura, exercícios físicos, etc..

Os envelhescentes e pessoas da terceira idade precisam dar continuidade às suas atividades físicas (da mente e do corpo). Ao longo dos anos, desde a infância até a idade adulta, eles estiveram descobrindo e estudando para atuarem profissionalmente a fim de obterem seu sustento. Ao saírem do mercado de trabalho, precisam refletir sobre a importância da continuidade de suas atividades, tanto do corpo como da mente, mas, ao mesmo tempo, precisam aprender a desacelerar o ritmo vivido durante toda a vida.

A terceira idade busca uma ressignificação em sua vida que conjugue prazer e ação, lazer e cidadania. Costa Lima (2014) identifica diferenças de comportamento entre 
os "produtivos" (pessoas da terceira idade aposentadas e reintegradas à sociedade) e os "improdutivos" (os que não mais desejam atuar no mercado de trabalho). E recomenda que, ao sair do mercado de trabalho, aposentando-se, os produtivos devem optar por não parar instantaneamente. O processo de deixar de ser produtivo deve acontecer de forma progressiva.

Hoje em dia, envelhescentes e pessoas da terceira idade têm consciência e controle sobre as suas ações sociais, experiências de vida e assumem um novo comportamento, desejando manter a sua função de ser guardião da memória social (COSTA LIMA, 2014).

\subsubsection{Envelhescentes e pessoas da terceira idade em busca de conhecimento}

Um dos fatores de crescimento pessoal é o conhecimento, que pode ser adquirido pelo acesso à educação, por experiências, por novas descobertas. Isso é possível graças ao processo de aprendizagem que acontece de forma contínua e por toda a vida. Sendo assim, é preciso desmistificar a crença de que os envelhescentes e pessoas da terceira idade são incapazes de aprender. Haddad (2000) chama a atenção para o fato de que, para a sociedade, pessoas nessa fase da vida são consideradas seres inúteis, não produtivas e que não possuem mais capacidade para buscar novos conhecimentos e oportunidades. Entretanto, "à medida que o indivíduo envelhece, sua capacidade intelectual torna-se mais aguda e mais seletiva [...] o intelectual idoso não diminui sua atividade mental. O que diminui é sua capacidade física" (HADDAD, 1986, p. 28-29). Dessa forma,

\footnotetext{
a educação para a Terceira idade remete ao verdadeiro sentido e objetivo da educação, como finalidade do processo civilizatório, aumento do nível intelectual e cultural dos cidadãos, uma teoria e uma prática de ação transformadora. (PONTAROLO; OLIVEIRA, 2008, p. 119)
}

Vemos a escola como a casa do saber, local seguro onde os pais deixam suas crianças a fim de que lhes sejam transmitidos novos conhecimentos. Assim como acontece com as crianças, envelhescentes e pessoas da terceira idade também necessitam evoluir, de forma a continuar tendo acesso a novos aprendizados (MENDES, 2012). No entanto, a educação e o aprender para os envelhescentes e pessoas da terceira idade têm sentido e objetivo diferentes do da infância e da adolescência. Procura-se a escola não apenas para a obtenção de um diploma, mas para estabelecer canais de comunicação com a sociedade: é também uma forma de sociabilização. 
Na década de 1980, a Organização das Nações Unidas para a Educação, a Ciência e a Cultura (United Nations Educacional Science and Cultural Organization) UNESCO, realizou estudos sobre a recondução da valorização para pessoas idosas e chegou às seguintes diretrizes:

1. Considerar menos o conteúdo e mais o despertar nela a capacidade de confiança em si mesma, de sua autonomia e o de desconstruir os estereótipos negativos que poderão estar influindo na sua vida. Aumentando o senso de suas responsabilidades, a pessoa idosa poderá melhorar sua saúde física e mental, o que contribuirá para que ela se afirme cada vez mais no dia-a-dia e no seu comportamento social;

2. Minimizar o isolamento, a solidão em que vivem muitos idosos, estimulando as relações com pessoas de sua geração e, também, com as de outras gerações; 3. Proporcionar conhecimentos práticos, específicos sobre, por exemplo, a passagem da vida ativa para a de aposentado, além de conhecimentos teóricos relativos ao processo de envelhecimento; ainda, atividades físicas, socioculturais e artísticas que possam interessar aos idosos;

4. Proporcionar a tomada de consciência das pessoas idosas da riqueza de sua vida pessoal e profissional e da importância da comunicação de sua experiência a outras gerações, desenvolvendo o equilíbrio e a compreensão mútua num mundo tão conflitado e que muda rapidamente. (SCHONS; PALMA, 2000, p. 162)

Essas diretrizes se referem a cursos e atividades educacionais desenvolvidas especificamente para o público formado por envelhescentes e pessoas da terceira idade. Para muitos envelhescentes e pessoas da terceira idade, a passagem pela escola pode não ter sido muito produtiva por várias razões: impossibilidade socioeconômica, restrição familiar, distância do local de moradia e falta de acesso, etc.. Entretanto, para outros, a escola pode ser sinônimo de boas recordações: ascensão socioeconômica, estímulo e valorização familiar, oportunidade melhor de aprendizagem, etc. Por isso, programas educacionais específicos para a envelhescência e terceira idade que valorizam a sua qualidade de vida e identidade própria são importantes.

Havendo oportunidade de uma participação ativa e de qualidade para envelhescentes e pessoas de terceira idade, o Brasil poderia oferecer uma nova experiência a esse público, dando-lhe a oportunidade de interação com os jovens, o que permitiria ganhos também a estes, que usufruiriam dos conhecimentos profissionais e de mundo que os envelhescentes e terceira idade podem compartilhar.

Atualmente, já há crescente busca de envelhescentes e pessoas da terceira idade por educação. Os que ainda estão no mercado de trabalho já começam a sentir a necessidade de obter aperfeiçoamento profissional (HADDAD, 1997). Dados do Censo da Educação Superior de 2014, compilados no Anuário Brasileiro de Educação Básica 
2016 e 2017 (TODOS PELA EDUCAÇÃO, 2016, 2017), evidenciam mudança no interesse pelo acesso à educação superior, que antecipam já os efeitos do impacto da mudança sociodemográfica (gráfico 2).

Gráfico 2: Distribuição das matrículas por faixa etária na educação superior nos anos de 2014 e 2015.
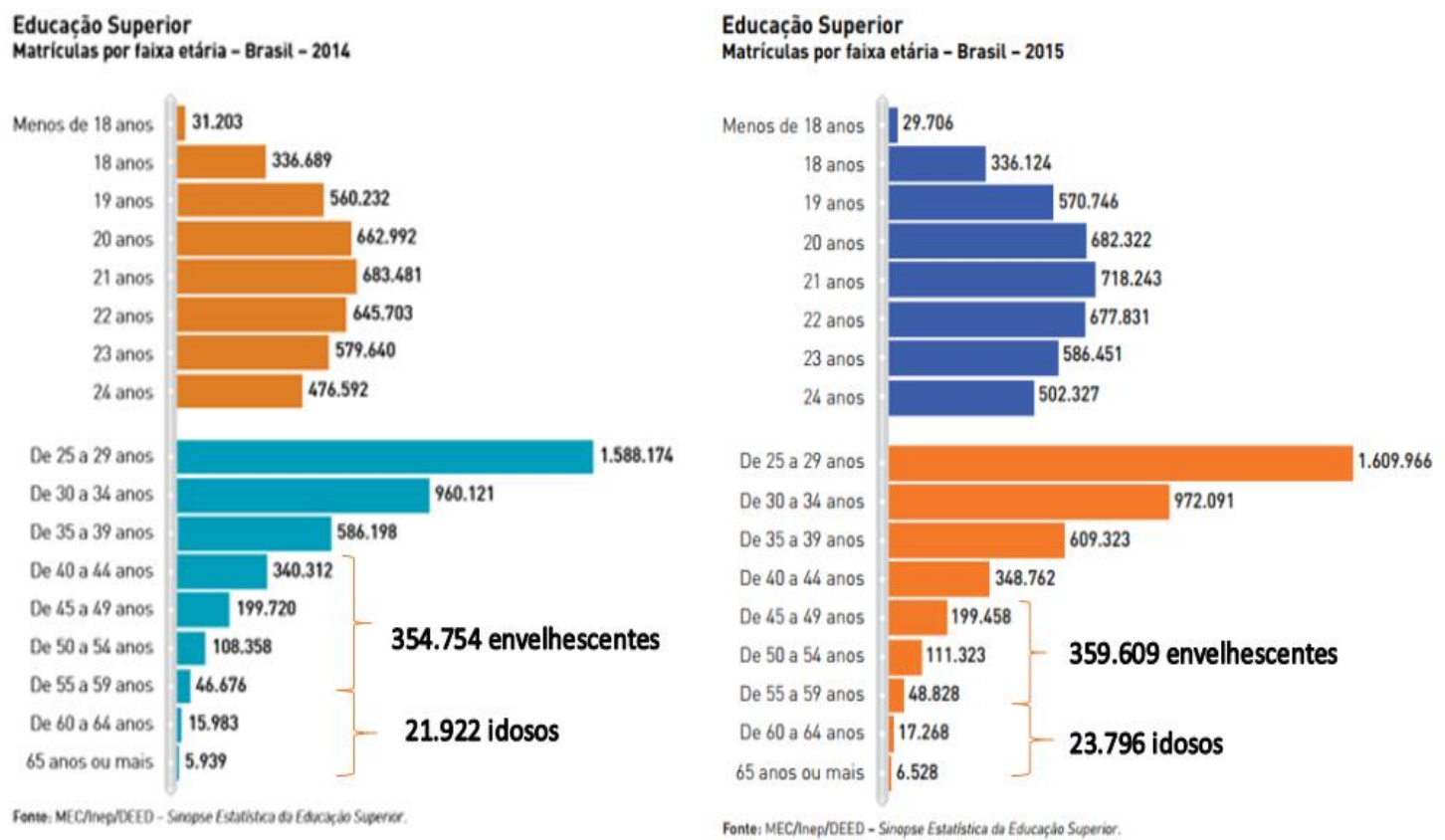

Fonte: Elaborado a partir de dados do Censo da Educação Superior, INEP.

Nos últimos anos, a expansão das matrículas nas Instituições de Ensino Superior (IES) do país foi uma constante e prospecta-se que, até 2025, haja ainda $58 \%$ de crescimento. O gráfico 2 evidencia a existência de mais de 700.000 pessoas com mais de 40 anos matriculadas na educação superior no Brasil. Esse número só tende a subir, já que a identidade demográfica do Brasil será modificada a partir de 2025, com a inversão da pirâmide etária.

Atualmente, os anseios e expectativas desse público são diferentes do público regular do ensino superior. Por exemplo, bolsas de programas institucionais de iniciação científica, extensão, docência, tecnológica, etc. geralmente são ocupadas por estudantes que não tenham vínculo empregatício ou renda; o público de mais de 40 anos, portanto, fica de fora dessas oportunidades de desenvolvimento. Num futuro próximo, a distribuição dessas bolsas deve ser repensada em atendimento às políticas de inclusão do público envelhescente e terceira idade. 


\subsubsection{Políticas públicas para envelhescência e terceira idade}

No novo milênio, o mundo lançou um novo olhar sobre as reivindicações por políticas públicas socioeducacionais. De acordo com essa nova demanda, é necessário fomentar espaços que propiciem à população da terceira idade o conhecimento de sua realidade, além de promover a qualificação dos profissionais da área e definir práticas que sejam adequadas às características dos alunos idosos, isto é, é preciso estar respaldado no reconhecimento dos direitos humanos estabelecidos pela Organização das Nações Unidas (ONU) e nos princípios da independência, participação, dignidade, assistência e autorrealização que visam ao seu desenvolvimento integral e proporcionam igualdade de oportunidade a todos.

A inversão na pirâmide etária, com muito mais idosos do que crianças, nos trará muitos impactos sobre como ressignificar a vida de todos nós nas relações familiares, sociais, profissionais, saúde e educacional.

Segundo Neri e Freire (2000), a qualidade de vida na velhice é o resultado da interação do homem com a sua história, ou seja, é o fruto da interação entre indivíduos, normas e valores sociais que sofrem alteração no decorrer do tempo.

Lawton (1991) propôs quatro aspectos que devem ser avaliados na qualidade de vida: 1) bem-estar psicológico; 2) percepção de qualidade de vida; 3) competências comportamentais; 4) objetivo do entorno físico.

Tal cenário obriga o Estado a dar uma maior proteção a crianças, envelhescentes e pessoas da terceira idade, ante sua fragilidade e necessidade de apoio em relação à saúde, à educação, a acesso à justiça, etc.. É preciso também dar maior proteção previdenciária ao público da terceira idade para que sejam garantidos os seus direitos pelos serviços prestados.

No Brasil, a partir da Carta Magna de 1988, cria-se a Lei 8.842/1994, conhecida como Política Nacional do Idoso, a qual sofreu várias alterações nos últimos anos. Problemas com a execução dessa lei resultaram na elaboração da Lei $n^{0} 10.741$, conhecida como Estatuto do Idoso, sancionada em $1^{\circ}$ de outubro de 2003 pelo Presidente Luiz Inácio Lula da Silva. Essa lei, em seu artigo $1^{\circ}$, tem como objetivo "regular os direitos assegurados às pessoas com idade igual ou superior a 60 (sessenta) anos de idade" (BRASIL, 2003).

Ainda assim, a Presidente Dilma Rousseff promulgou um Decreto-Lei sobre o Estatuto do Idoso, em $1^{\circ}$ de outubro de 2013, dia nacional do idoso, para estabelecer que 
se faça cumprir a lei já em vigor há 10 anos, bem como dar encaminhamentos para o Estado se responsabilizar por uma melhor assistência ao idoso, auxiliar nas construções de casas adaptadas e assegurar o direito legal de estudo nas Universidades Abertas.

No Título I, nas disposições preliminares dos três primeiros artigos da legislação atual, define-se "idoso" a partir de 60 sessenta anos de idade, ao qual se deve oferecer todas as oportunidades e facilidades, para preservação de sua saúde física e mental e seu aperfeiçoamento intelectual, espiritual e social, em condições de liberdade e dignidade. $\mathrm{Na}$ sequência dos artigos, são definidas as obrigações da família e da comunidade, da sociedade e do Poder Público e a efetivação do direito à vida, à saúde e à alimentação dos idosos, o que pode ser sumarizado do seguinte modo:

- A população em geral ainda não tem consciência plena dos itens da lei, de sua aplicabilidade e de sua prioridade;

- A lei chama a atenção para novas formulações e execuções de políticas públicas sociais específicas;

- A lei prevê a garantia de proteção ao idoso;

- É objeto da lei prever a ocupação e o convívio com o idoso das demais gerações;

- A lei destaca a priorização do atendimento ao idoso por sua própria família;

- Faz-se necessário investir em capacitação e reciclagem dos recursos humanos nas áreas de geriatria e gerontologia e na prestação de serviços aos idosos;

- O favorecimento de divulgação de informações de caráter educativo sobre os aspectos biopsicossociais de envelhecimento;

- A lei prevê garantia de acesso à rede de serviços de saúde e de assistência social local e prioridade no recebimento da restituição do Imposto de Renda (incluído pela Lei no 11.765/2008).

Tendo em vista a melhoria da qualidade de vida, o art. 20 do Estatuto do Idoso prevê a inserção desse grupo populacional em atividades educativas: "o idoso, nos termos da lei, tem direito à educação, cultura, esporte, lazer, diversões, espetáculos, produtos e serviços que respeitem sua peculiar condição de idade" (BRASIL, 2003).

Embora a lei vigente proteja e dê o direito de acesso a universidades, com a garantia de que "o Poder Público criará oportunidades de acesso do idoso à educação, 
adequando currículos, metodologias e material didático aos programas educacionais a ele destinados" (Art. 21 do Estatuto do Idoso), envelhescentes e pessoas de terceira idade passam por muitas dificuldades para ter acesso a esse direito, que muitas vezes os fazem desistir. Necessitam fazer um cadastro para pleitear vaga nos projetos ou cursos de extensão e solicitar o que lhes interessam. Entretanto, essas escolhas são limitadas ante a pouca oferta de cursos destinados a esse público ${ }^{5}$.

Para Costa Lima (2014) e Pereira (2014), as universidades precisam investir na formação de profissionais, particularmente nos campos da educação e saúde, aptos a trabalhar com as especialidades desse contingente populacional. Trata-se de uma oportunidade de os professores desenvolverem projetos nas universidades direcionados à formação de futuros professores que se qualifiquem para atuar na educação de envelhescentes e pessoas da terceira idade.

Knowles, Holton III e Swanson (1998) enfatizam que:

a andragogia é uma ciência que procura desenvolver uma teoria específica para a aprendizagem relacionada a pessoas adultas. Conforme o autor, na Andragogia, assim como na teoria Humanista, acredita-se que a aprendizagem significativa leva a insights que fazem com que as pessoas entendam a si mesmas e aos outros. (KNOWLES; HOLTON III; SWANSON, 1998, p. 4)

Assim, é preciso que os docentes estejam preparados para lidar com esse público. O número de ingressantes envelhescentes e da terceira idade no ensino superior é

\footnotetext{
${ }^{5}$ A Universidade Federal de Sergipe tem atuado na inclusão de pessoas da terceira idade em seu espaço, por meio das ações do Núcleo de Pesquisa a Terceira Idade (Nupati). O Nupati foi criado no dia 10 de setembro de 1998, pela Portaria $\mathrm{n}^{\circ} 748 / \mathrm{GR}$, com a finalidade de promover a cidadania da pessoa da terceira idade, desenvolvendo ações integradas que mobilizam as finalidades da universidade: ensino, pesquisa e extensão. No âmbito institucional, é o Nupati que tem implementado as ações previstas no Estatuto do Idoso, com o objetivo maior de conscientizar as pessoas da terceira idade, bem como o corpo docente e funcionários a se engajarem nesses grupos para se manterem mais saudáveis e poderem alcançar a longevidade com ocupações voltadas para a educação, conforme garante o Estatuto do Idoso nos capítulos $\mathrm{V}$, artigos 20-25, e VI, artigos 26-28. Para atender o que determina a legislação vigente no país, a portaria $\mathrm{n}^{\mathrm{o}}$ 906, de 19 de dezembro de 2003, a fim de regulamentar o ingresso do idoso (60 anos ou mais) em disciplinas do curso de graduação, criou a Universidade Aberta à Terceira Idade de Sergipe (Unatise). Além de garantir o direito de acesso a disciplinas de graduação, a Unatise também oferece oficinas lúdicas, bordado, memórias e sarau literário, minicursos, semanas de estudos sobre temas atinentes a esse púbico. É preciso considerar que os cursos não são oferecidos pelo próprio Nupati, mas pelos departamentos, e não existe um planejamento anterior à execução das ações dos docentes da UFS. Existe apenas um convite oficial/formal, via comunicação interna, para que os idosos que desejam cursar as disciplinas da matriz curricular dos cursos de graduação possam ser inseridos nas disciplinas; os alunos têm as mesmas obrigações que os alunos regulares, mas o que observamos, no entanto, é que os idosos não conseguem acompanhar o ritmo de aprendizagem como também as avaliações. Uma nova Portaria, $\mathrm{n}^{\circ} 0492$, de 11 de março de 2015, retificou a Portaria $\mathrm{n}^{\circ} 748 / 1998$, determinando que passarão a atuar no Nupati membros do Departamento de Serviço Social do Centro de Ciências Sociais Aplicadas (DSS/CCSA) e do Colégio de Aplicação (Codap), a partir de 11 de março de 2015. Para maior detalhamento sobre a Unatise, reportamos o trabalho de Silva (2016).
} 
crescente. Ante essa nova demanda, é importante que haja mudanças na matriz curricular dos cursos de formação de professores de todas as IES para se adequarem às necessidades específicas ligadas àquele público.

No cenário atual, faz-se necessário que a educação superior ofereça uma melhor e mais ampla formação intelectual e profissional, valorizando esse público de forma crítica e consciente sobre sua participação e inserção na sociedade. No entanto, apesar de a legislação prever, como vimos no Artigo 22 do Estatuto do Idoso, a abordagem do tema não é institucionalizada nos componentes curriculares dos cursos, pelo menos no curso de Licenciatura Letras-Inglês da Universidade Federal de Sergipe. Esse tema, se abordado, é por iniciativa de algum docente que deseja inserir essa discussão em suas aulas e ou em projetos de extensão.

Diante da realidade do aumento da expectativa de vida da população brasileira comprovado por dados estatísticos, diante do acesso mais frequente de envelhescentes e pessoas da terceira idade às universidades e diante da legislação vigente, que assegura o direito a educação com metodologias que se adequem a suas especificidades, faz-se mister que professores e alunos das universidades comecem a despertar para novos aprendizados profissionais e possam, assim, se preparar de forma específica para atender a esse público, de modo que a aprendizagem de uma língua estrangeira seja apenas uma das possibilidades de inserção social, que lhes permita novos sentidos e ressignificação da vida.

\subsubsection{Aprender uma nova língua na envelhescência e na terceira idade}

Numa sociedade com tamanha variedade de culturas e línguas, tendo à sua disposição as facilidades de comunicação por meio de novas tecnologias, intensifica-se a busca por diversificados tipos de conhecimentos, inclusive a aprendizagem de novas línguas.

A participação de envelhescentes e pessoas da terceira idade em curso de uma língua estrangeira, além de promover novos conhecimentos de uma nova língua, proporciona novas relações sociais entre sujeitos de várias idades (PIZZOLATTO, 2008). Dessa forma, tanto os aprendizes quanto os ministrantes devem saber lidar com a realidade do ensinar e do aprender a língua.

No cenário atual, envelhescentes e pessoas da terceira idade acompanham o ritmo acelerado da modernidade, não só navegando pela internet para obter novas experiências 
de aprendizagem, protegendo-se de possíveis doenças e de perdas cognitivas ao utilizar o conhecimento adquirido, mas também almejando aprender uma nova língua para, nessa nova fase da vida, adquirir conhecimentos sobre a cultura do país que gostariam de visitar.

Embora envelhescentes e pessoas da terceira idade estejam conscientes dos seus direitos sob a legislação atual, faz-se necessário entender essas mudanças para ajudar a romper com o estereótipo de que as pessoas em processo de envelhecimento não têm mais idade para aprender. Na contramão desse estereótipo, os envelhescentes se motivam cada vez mais para aprender uma língua estrangeira, desmistificando alguns preconceitos sobre a impossibilidade de aprendizagem na envelhescência e na terceira idade.

Como em 2025 a maior parte da população será de envelhescentes e de pessoas da terceira idade, o mercado de trabalho necessita formar mão de obra especializada para o ensino de inglês em todas as unidades educacionais. É preciso pensar em políticas públicas que se adequem às demandas necessárias a esse público específico, podendo proporcionar a todos eles uma melhor qualidade de vida ao darem continuidade aos estudos; no nosso caso, proporcionar o aprendizado de uma língua estrangeira - o inglês - contribuindo, assim, para reativar o circuito neuronal, evitando possíveis doenças degenerativas e fazendo com que eles mantenham sua cognição.

Como veremos a seguir, envelhescentes e pessoas da terceira idade têm consciência de modificar o comportamento pessoal por meio do exercício da percepção, da atenção, da concentração, respeitando-se, é claro, o ritmo de aprendizagem de cada um. Por vezes, eles necessitam repetir reiteradamente, por exemplo, a pronúncia de determinadas palavras ao estarem aprendendo uma língua estrangeira. Quando a repetição não é suficiente para a aprendizagem, cabe ao profissional que atua com esse público criar estratégias que façam com que o objetivo seja atingido. Para isso ele precisa ter uma formação diferenciada, na medida em que, nesse processo de aprendizagem, estão envolvidos aspectos cognitivos e neuronais diferentes.

\subsection{TEMPO COGNITIVO}

O conceito de cognição é utilizado para nos referirmos às atividades mentais como ver, entender, lembrar e resolver problemas. Está relacionado aos processamentos das informações transmitidas que operam em duplo sentido, que vai do emissor ao receptor e vice-versa. Esse conceito se insere em estudos voltados para as áreas do circuito neuronal e da psiquiatria ligada à neurociência. Dehaene (2012) afirma que a cognição abrange as 
ações mentais e, por esse motivo, não é possível saber de tudo, por essas ações mentais serem privativas dos pensamentos secretos. Não são observáveis a olho nu, mas podem ser estudados cientificamente com base em evidências indiretas, através do comportamento individual do ser, das expressões da fala e de hipóteses.

Além das teorias comportamentais, as novas teorias foram estudadas através da percepção, da atenção, da memória, da fala, de solução de problemas, da informação selecionada, codificada e armazenada, dando maior importância ao processamento de interação e entorno com o outro. A psicologia estuda os processos cognitivos de percepção, atenção, retenção temporária e permanente, a compreensão da fala, a retenção e produção da aprendizagem conceitual e de raciocínio, bem como a resolução de problemas e o raciocínio dedutivo. A aprendizagem acontece quando habilidades são automatizadas.

As áreas da neurologia, da psiquiatria, da filosofia, da antropologia e computacional são alguns exemplos de áreas científicas que interagem com estudos sobre a manutenção do bem-estar cognitivo do ser humano. Elas contribuem para que se evitem demências em decorrência do processo natural do envelhecimento.

A dimensão do tempo cognitivo que influencia o aprendizado de uma língua está relacionada fisiologicamente com os processos da linguagem, como podemos ver a seguir.

\subsubsection{Tempo de execução de tarefas e envelhecimento}

Ainda que a idade de 60 anos seja o início do envelhecimento, oficialmente decretado pela lei vigente nacional, não podemos afirmar que uma pessoa nessa idade esteja idosa. O fato é que toda pessoa no processo de envelhecimento passa por modificações no desempenho cognitivo. Os sinais dessas modificações vão aparecendo aos poucos ou mais acentuadamente a depender da pessoa. Na maioria dos casos, quando não se trata de doença degenerativa, é um processo natural de uma nova fase de início da senilidade.

Para entender a cognição humana, é preciso desvendar os segredos do cérebro. No século XIX, Vigotski (2000) fazia experiências com animais e percebia que eles davam respostas positivas depois de serem estimulados. Essas experiências fizeram com que os estudos sobre o cérebro humano avançassem, aplicando a mesma técnica de estímulo- 
resposta. O avanço da ciência tem contribuído com a correção de imperfeições da natureza e promovido melhor qualidade de vida ao ser humano.

Atualmente é possível a identificação das áreas cerebrais onde existem patologias físicas, cognitivas ou sensoriais, como AVC, meningite, doenças degenerativas, esclerose múltipla e doenças dos cérebros. Áreas do conhecimento como neurologia, fisioterapia e fonoaudiologia têm atuado na pesquisa de patologias e demências ligadas à senilidade. Estudos neurolinguísticos têm evidenciado a relação entre neurônios, linguagem e envelhecimento.

O cérebro é um órgão que faz parte do sistema nervoso que comanda as emoções do consciente e do inconsciente. Izquierdo (2004), Gabriel (2004), Dehaene (2012), Lent (2005), Bialystok, Craik e Ruocco (2006) têm se dedicado a estudar a prevenção de demências cerebrais e a atuação do cérebro e da mente a fim de compreender como os neurônios funcionam no processo de aprendizagem de uma língua estrangeira.

Segundo Lent (2005), o neurônio é a unidade básica do processamento da informação. Ele é considerado a unidade morfofuncional situado no sistema nervoso que produz e veicula diminutos sinais elétricos, que são verdadeiros bits de informações, capazes de codificar tudo que sentimos, a partir do ambiente externo e interno, e tudo que pensamos. Seu tamanho é variável, mas, em média, mede um micrometro.

Ainda segundo Lent (2005), os neurônios operam em conjunto, emergindo aptidões mentais e cognitivas, memórias, inteligências e emoções. Embora não exista um controle de seu desenvolvimento individual, os estudos confirmam que as células nervosas crescem e podem ser modificadas a depender de respostas a experiências positivas e ou negativas.

O neurônio faz várias conexões ao mesmo tempo. Cada conexão chama-se sinapse. Possuímos a capacidade de receber muitas informações ao mesmo tempo, inclusive sobre as percepções da emoção. De acordo com Dehaene (2012), no processamento da leitura, por exemplo, os estímulos visuais ativam milhões de neurônios simultaneamente das regiões cerebrais encarregadas por essa tarefa.

Apesar de haver uma pré-disposição genética que diferencie a capacidade cognitiva de cada ser humano, isso não é obstáculo à aprendizagem: experiências e estímulos podem suprir a carência genética.

Izquierdo (2011) conceitua a memória como a aquisição de informações provenientes de dentro dos sujeitos. Contudo, a capacidade de manter essa memória ativa varia de acordo com a idade: o jovem adquire e conserva a memória com muito mais 
facilidade do que as pessoas que atingem a terceira idade. A memória dessas pessoas registra os fatos do passado, de quando eram jovens, mas os registros atuais já não são marcados com tanta facilidade.

A memória é um elemento essencial para que haja aprendizagem. Existem vários tipos de memória: memória curta, memória de longo prazo, memória associativa. Isso está relacionado à plasticidade sináptica. O processo de recuperação das informações se dá através da ativação de neurônios específicos, o que pode ativar as memórias armazenadas durante a passagem pelas várias faixas etárias. Quando a pessoa atinge a idade adulta e, posteriormente, a terceira idade, é natural que aconteça algum tipo de diminuição da plasticidade neural ou sináptica por questões biológicas, acarretando dificuldade de lembrar. Entretanto, para se ter qualidade de vida, é preciso continuar obtendo a independência do saber selecionar, organizar e executar as ações interligadas ao comando cerebral.

Assim, mesmo que o sujeito esteja com a capacidade cognitiva normal, faz-se necessário que mantenha as atividades do cotidiano, a fim de que não surjam problemas de doenças neurológicas futuros. Observe-se também que o ritmo do 'tempo' de execução das tarefas pode aumentar drasticamente quando a pessoa está enferma ou em idade mais avançada.

As demências neurodegenerativas podem acelerar o processo de envelhecimento, mas se envelhescente e pessoa da terceira idade se conscientizarem e trabalharem as funções cognitivas, é possível um retardamento do processo degenerativo e sua qualidade de vida será melhor.

No processo normal de envelhecimento, as famílias não estão atentas aos comportamentos dos envelhescentes e das pessoas de terceira idade, o que, por vezes, não permite detectar algumas possíveis demências nesses familiares. $\mathrm{O}$ envelhecimento fisiológico está associado a um declínio gradual nas funções cognitivas. Dificuldade para recordar nomes de pessoas, números de telefone e objetos guardados são as manifestações mais comuns. Esse declínio da cognição, que acompanha o envelhescimento, tem início e progressão variáveis, dependendo de instrução, nível intelectual, saúde, personalidade e da capacidade mental individual (REIS et al., 2009).

O diagnóstico cognitivo comportamental é muito complexo devido à variedade de grupos de pessoas da terceira idade que possuem histórico hereditário. Além disso, a falta de conhecimento sobre essas enfermidades e a falta de observação do idoso por parte dos familiares dificultam ou retardam a procura por um diagnóstico e possível tratamento. 
Segundo Engelhardt et al. (1998), existem quadros de pacientes leves de comprometimento cognitivo que são frequentes, passando muitas vezes despercebidos, e há uma necessidade de distinguir entre as manifestações iniciais de doença e modificações associadas ao processo normal de envelhecimento.

Pesquisas têm revelado que o grau de escolarização interfere no processo de envelhecimento do cérebro, atuando como um fator de proteção neuronal. O desempenho de indivíduos testados com instrumentos de avaliação cognitiva é fortemente influenciado pela escolaridade. Reis et al. (2009) desenvolveram testes de aptidão cognitiva cujos resultados da aplicação entre idosos de 65 a 80 anos de idade evidenciam melhor desempenho entre aqueles que estudaram em detrimento daqueles que não estudaram.

Nas funções cognitivas, $40 \%$ dos sujeitos apresentavam estado preservado e $60 \%$ dos demais idosos apresentavam alguma alteração cognitiva entre 60 e 80 anos de idade. Não é só a idade que influencia no processo de alteração cognitiva, a escolarização também: quando se estimula os hemisférios do cérebro, a tendência é de se preservar mais pelas ações neuronais, para uma melhor qualidade de vida. No entanto, Reis et al. (2009) enfatizam o quão difícil é falar cientificamente sobre os desempenhos cognitivos entre participantes escolarizados e não escolarizados devido ao fator da ciência e motivação individual que cada participante possui.

Embora as alterações cognitivas possam levar ao surgimento de demências, existe muita dificuldade de se diagnosticar o grau de declínio não-patológico do patológico (COELHO et al., 2012). Mas, mesmo diante dessa dificuldade, resultados de estudos evidenciam que pessoas da terceira idade que não tiveram acesso à escolarização apresentam menor desempenho em alguns dos testes cognitivos.

Os estudos de Xavier e Parente (2006) e Ávila et al. (2009) evidenciam que houve influência significativa na velocidade de processamento, atenção, funções executivas, memória e inteligência sobre as tomadas de decisões em dois grupos de participantes: idosos com escolarização e sem escolarização. Os autores ratificam a importância da continuidade de estudos das pessoas no processo de envelhecimento, a fim de praticar ações que envolvam o raciocínio do circuito neuronal para tornar o cérebro mais resistente a possíveis declínios.

Na mesma direção, Coelho et al. (2012) mostram que pessoas envelhescentes e da terceira idade que praticam atividades físicas sistematizadas e regulares melhoram substancialmente as funções cognitivas e também o desempenho cognitivo, diferentemente do grupo de pessoas do mesmo público que não praticava atividades 
físicas. Nesse estudo, Coelho et al. (2012) visavam a avaliar o desempenho cognitivo de memória de curto prazo, linguagem, aprendizagem, o grau de esquecimento e funções executivas em diferentes níveis escolares de adultos e idosos praticantes de atividades físicas por um tempo superior a seis meses. O projeto AFRID (Atividade Física Recreativa para a Terceira Idade, da Universidade Federal de Uberlândia) envolve 132 participantes com a idade a partir de 45 anos e 60 anos com o objetivo de manter a qualidade de vida. Dos 132 participantes, dez apresentaram Mini Exame do Estado Mental (MEEM), com resultados abaixo da média de escolaridade. E, diante desse resultado, ficaram apenas 122 indivíduos sem perdas cognitivas entre as idades de 46 a 85 anos. Foi utilizado o teste WMS-R, para avaliar a aprendizagem e a taxa de esquecimento, entre palavras sequenciais, e o Mini Exame do Estado Mental (MEEM), composto por questões agrupadas, orientação sobre o tempo, local, registro de três palavras, linguagem e capacidade visual construtiva; o score desse teste varia de 0 a 30 pontos, e, quanto mais baixo for o valor, pior está o desempenho cognitivo (COELHO et al., 2012).

Além desses testes, foram aplicados o teste do desenho do relógio (TDR), um relógio com inversão de letras e o teste de fluência verbal semântica (TFV), que é um instrumento simples que avalia o desempenho em relação às respostas em um número maior possível da mesma categoria semântica em um minuto. Os resultados do estudo de Coelho et al. (2012) apontaram que os idosos praticantes de atividades física é similar para os diferentes níveis de escolaridade, mas que os estudos são inconclusívos, necessitando efetuar, em novas pesquisas, se a atividade física exerce efeito protetor nas funções cognitivas independentemente do nível de instrução do indivíduo.

Observemos a seguir as decisões que envelhescentes e pessoas da terceira idade tomam em ações de uma atividade lúdica, conforme o estudo de Santos, Rosseti e Ortega (2006), segundo o qual o funcionamento de tomada de consciência de idosos e adolescentes no contexto de jogos de regras favorece a relação social entre jovens. Em uma abordagem exploratória de natureza qualitativa, com dois adolescentes e dois idosos jovens, em um jogo de regras chamado Quoridor, os participantes utilizaram estratégias para vencer o jogo. Foi realizado experimento para checar a cognição entre as tomadas de decisões dos grupos de participantes jovens e idosos e o resultado evidenciou que, embora os idosos sejam mais lentos nas ações, eles conversavam mais entre si para chegar no alcance final de vencer o jogo, enquanto os participantes jovens também, mas com menos estratégias. Esse resultado denota que a habilidade da experiência de vida 
favoreceu o sucesso de ter vencido o jogo, embora tenha maior demanda de tempo na tomada de decisão.

Obler e Pekkala (2008) investigaram problemas de linguagem e a comunicação no envelhecimento. As pessoas idosas se queixam de problemas auditivos em situações de locais barulhentos como também de ter dificuldades em identificar certos tipos de palavras. Também sabemos, em relação à língua, que, com o passar da idade, há mudanças na saúde dos idosos em relação à verbalização (processo cognitivo): “A compreensão da recuperação dos aspectos lexicais para narrar e soletrar podem acontecer. Em outras áreas da linguagem, mostram pouco ou nenhum declínio em relação ao avanço da idade" (OBLER; PEKKALA, 2008, p. 351). ${ }^{6}$ Isso significa que, mesmo tendo-se alguma perda de cognição, as pessoas podem demonstrar poucas áreas afetadas e manter outras regiões da área da linguagem ativa.

Do mesmo modo, os estímulos podem devolver a pessoas de terceira idade a manutenção de cognição e motivação em exercitar as línguas. As funções fisiológicas vão variar de acordo com o estilo de vida dos sujeitos da terceira idade.

Obler e Pekkala (2008) destacam que pode haver problemas com respeito à recuperação de identificar a palavra específica, por exemplo, em tarefas de identificação de palavras ou tarefas que sejam para confrontar nomes, tarefas sobre a definição e fazer inversão de conceitos para serem identificadas as palavras. Os autores reportam o estudo de Bowles, Grimm, McArdle (2005), que constataram que, em relação ao uso de vocabulário, há um declínio significativo com o avanço da idade do que o próprio avanço do vocabulário entre indivíduos de 35-70 anos, assim como o pico da idade aguçada é de 50 anos e posteriormente inicia o declínio.

Por que os adultos mais velhos têm problemas com lembranças de nomes e coisas? Burke e Shafto (2004) conduziram uma série de estudos para responder a essa questão. O modelo aplicado foi "a hipótese de déficit de transmissão", segundo o qual as palavras são elencadas em uma via semântica, fonológica e ortográfica para que, juntas, facilitem

\footnotetext{
6 "Comprehension problem can also be observed, specially for auditory material that consists of complex text or is produced in stressful (such as noisy) conditions. Discourse patterns may change as well, depending on the nature of the tasks eliciting them. For elders who are bilinguals, these problems may be accompanied by attrition or less-used language. More severe lexical-retrieval and comprehension problems are seen in elderly individuals who display mild cognitive impairment (MCI) or progress to Alzheimer's disease (AD) and all aspects of language and communication are impaired in the late stage of Alzheimer's dementia. Age-related language changes have been explained as language-specific or related to cognitive abilities such as memory and attention, and have been attributed to areas of the brain that undergo substantial agerelated changes."
} 
a compreensão do conhecimento da palavra com a ativação cognitiva, que, com o avanço da idade, sofrem efeito de falta da atenção e memória, processos mentais que podem declinar com avanço da idade. Os resultados apontam que participantes mais velhos tendem a experienciar mais palavras problemáticas do que os mais jovens. Eles experienciaram esses testes como em outra língua, ou eles omitem elementos em aplicar lapsos da língua. A expressão "na ponta da língua" ocorre quando as marcas da língua fonológica do item lexical não atingem a saída suficientemente; o falante conhece a palavra, mas é incapaz de pronunciá-la no exato momento.

No início do envelhecimento, os problemas de compreensão estão relacionados a vários fatores cognitivos, que podem ser diagnosticados de acordo com a situação dos sujeitos, tais como o problema sobre a rapidez ou lentidão da compreensão do texto em áudio (WINGFIELD; PEELLE; GROSSMAN, 2003); a dificuldade em reconhecer sotaques, variantes fonológicos que determinam a região do falante, e, por isso, nem sempre o sujeito envelhescente terá a habilidade em detectar a origem do falante (BERGMAN, 1980). Burke e Shafto (2004) evidenciam que os problemas de compreensão podem estar voltados para as estruturas complexas de sintaxe e que as pessoas da terceira idade necessitam usar inferência para poder compreender o texto.

Reis et al. (2009) relataram a carência de estudos na terceira idade e que o estudo de uma língua estrangeira seria como um efeito terapêutico, preventivo de doenças do cérebro. Por isso é de grande importância uma pesquisa que venha contribuir com futuros resultados de prevenção dessas demências causadas talvez pela falta do exercício de uso do cérebro. Na realidade de países em desenvolvimento, como o Brasil, o grande número de pessoas com pouco ou nenhum grau de escolaridade releva a necessidade da existência de políticas públicas voltadas à prevenção e ao tratamento dessas possíveis doenças de grau leve ou de grau patológico, cuja incidência aumenta rapidamente diante da faixa etária de 80 a 90 anos. Uma estratégia para o controle desse aceleramento na perda de cognição é o estudo de uma língua estrangeira, por estar ativando os dois lados do hemisfério (esquerdo e direito), como veremos a seguir.

\subsubsection{Linguagem, cognição e envelhecimento}

Existem muitas teorias para a aquisição da linguagem. Todas elas têm em comum o fato de que é da natureza humana nascer com a possibilidade de poder falar e que o desenvolvimento da fala envolve a maturação fisiológica. Em seu desenvolvimento 
fisiológico, ao adquirir os primeiros comportamentos da fala, a área frontal do cérebro de uma criança é a última a se formar no seu desenvolvimento normal (entre 0-4-5 anos de idade) e é a primeira a ser degenerada na terceira idade quando acometido de demências (LENT, 2005).

Muitos estudos evidenciam que aprender uma língua estrangeira é um exercício que pode reativar o circuito neuronal entre os hemisférios do cérebro (LENT, 2005, BIALYSTOK; CRAIK; RUOCCO, 2006). Essa compreensão é atribuída à área frontal do cérebro, que é a base da atenção e da realização das tarefas simultâneas. Bialystok, Craik e Ruocco (2006) evidenciam que, ativando os dois hemisférios do cérebro, o ensino de uma língua estrangeira faz com que pessoas da terceira idade exercitem o cérebro e gerenciem a sua atenção o tempo inteiro, muito mais que os monolíngues, tornando-os mais eficientes e mais fortes. Bialystok, Craik e Ruocco (2008) defendem que, do ponto de vista fisiológico e cognitivo, ser bilíngue só traz vantagem. Segundo Obler e Pekkala (2006), os bilíngues usam o lobo frontal, aprimorando o cérebro como compensação do declínio da função medial; em termos de uso, isso significa que

\footnotetext{
Pessoas que dominam mais de uma língua, têm mais vantagens do que aqueles que falam apenas a sua língua. [...] outros estudos indicam que as pessoas idosas bilíngues, que têm uma longa experiência em usar duas línguas têm desenvolvido melhores funções da área da memória executiva nos quais podem ser mais eficazes no uso do processamento da língua do que os adultos mais velhos monolíngues. [...] com o objetivo de superar dificuldades dos nomes da memória, ambos falantes monolíngues ou bilíngues podem usar estratégias diferentes, assim como evitar o uso das expressões e signos linguísticos. Os idosos bilíngues podem também se apropriar de palavras de outras línguas ou intercalar de uma língua para outra, se o interlocutor falar ambas as línguas. (OBLER; PEKKALA, 2008, p.353); (tradução nossa)7 .
}

Tendo em vista essas constatações, envelhescentes e pessoas da terceira idade precisam ser estimulados a desenvolver a área frontal do cérebro. Aprender uma língua estrangeira é um incentivo ao exercício entre as conexões neuronais. Tendo as sinapses reativadas, o aprendiz da terceira idade se motiva e se interessa para desenvolver outras tarefas de aprendizagem (BIALYSTOK; CRAIK; RUOCCO, 2006). Esse exercício das conexões neuronais vai favorecer as pessoas envelhescentes e da terceira idade a

\footnotetext{
7 "People who master more than one language have advantages over those who master only one. [...] Other studies indicate that those elderly bilinguals who have lifelong experience in using two different languages have developed better executive function and working memory, which they can more effectively use for processing language than monolingual older adults. [...] In order to overcome such naming difficulties, both monolingual and bilingual adult speakers may use different strategies such as avoidance, rephrasing, and circumlocutions. Bilingual elders, as well can borrow words from the other language or code-switch from one language to the other, if the interlocutor speaks both languages." (OBLER; PEKKALA, 2008)
} 
manterem os dois hemisférios cerebrais simultaneamente em relação ao vocabulário de ambas as línguas, além de outros processos de prevenção contra demência, chamando a atenção para as ações individuais de aprendizagem.

Lent (2005) subdivide as ações de tarefas a serem executadas pelo cérebro em funções específicas e funções globais. As primeiras estão ligadas ao hemisfério esquerdo do cérebro, onde estariam as atividades dos cálculos dos números, fala, escrita, identificação de pessoas, parte motora lateral, identificação de objetos e animais, compreensão linguística, leitura e relações espaciais qualitativas e, sendo assim, as articulações da fala sobre a organização sistêmica de cada língua, letras, palavras, frases e verbalização, saber fazer a seleção de números, diferenciar as pessoas entre si, a parte motora e a compreensão linguística no espaço global em que se vive.

Segundo Lent (2005), o conceito de especialização superou o conceito antigo de dominância pelo qual um dos hemisférios do cérebro faria tudo, sendo o outro 'uma reserva técnica coadjuvante'. As funções globais do cérebro estão ligadas diretamente ao hemisfério direito. As tarefas são identificadas como: identificação de pessoas, objetos, compreensão musical, bem como as relações espaciais qualitativas. No entanto, questões sobre linguagem articulatória estão voltadas para o hemisfério esquerdo e o hemisfério direito é voltado para conotação, ironia, aspectos discursivos e pragmáticos. Scherer e Gabriel (2007) subdividem o uso das tarefas dos hemisférios cerebrais em core coding e fine coding como um entrelaçamento das tarefas globais e específicas em que estejam sendo utilizadas no momento das ações de suas tarefas.

Lent (2005) enfatiza as funções globais do hemisfério esquerdo do cérebro, praticamente o responsável por tantas identificações, por outro lado, o hemisfério direito seria o corresponsável pelas emoções e compreensão da linguagem. Assim, não se pode afirmar com precisão se existem essas divisões de tarefas sobre articulação da fala e sua compreensão, por exemplo. Portanto, os hemisférios cerebrais se entrelaçam fazendo individualmente as suas seleções; quando é necessário o core coding, o hemisfério direito é o responsável pelas possíveis significações da palavra, e o hemisfério esquerdo para selecionar dentre as opções disponibilizadas, a mais adequada para o contexto a ser inserido, o chamado fine coding (SCHERER; GABRIEL, 2007).

Entendemos essas tarefas das acepções do conhecimento sistêmico a serem executadas nos dois hemisférios cerebrais como as mais coerentes para identificação do uso da palavra adequada pelo cérebro e fazer a opção de escolha de acordo com a seu grau de conhecimento da língua e visão sobre o assunto. 
Neurônios podem ser estimulados ou enfraquecidos de acordo com os padrões de ativação das áreas neuronais. Por isso, quando as pessoas envelhecem e se isolam passam a perder muitas das acepções cognitivas e metacognitivas, a começar pela carência do cuidado pessoal (GABRIEL, 2004). Assim como nas crianças, os envelhescentes e pessoas da terceira idade não podem se isolar do meio social em que vivem. Eles precisam ser participativos para alimentar as acepções cognitivas e metacognitivas dentro das suas ações na sociedade. E aprender uma língua estrangeira pode ser uma excelente estratégia para manter a atividade cognitiva e sócio pessoal desse público específico, a desafiar-se com novas atitudes de aprendizagem.

O envelhecimento traz declínio cognitivo pelo desgaste natural biológico da idade. Diante desse impacto, evidências em pesquisas sobre o bilinguismo mostram como é possível a obtenção de proteção contra o declínio cognitivo no envelhecimento.

Billig e Finger (2016) realizaram um estudo sobre a memória de trabalho de idosos e adultos, com a participação de 136 participantes bilíngues e monolíngues. Esse teste foi aplicado com o propósito de avaliar a preservação da memória de trabalho, manutenção e manipulação das ações e serve para medir o tempo dessas funções. Os resultados desse estudo revelaram que bilíngues e monolíngues se comportaram de maneira semelhante em termos de acurácia, mas os idosos bilíngues foram mais rápidos do que os idosos monolíngues. $\mathrm{O}$ exame dos resultados das tarefas executivas revelou menores custos cognitivos para os bilíngues, e, com isso, a diferença do desempenho entre adultos e idosos em termos de tempo de reação foi entre os bilíngues, sugerindo que o estudo de uma língua estrangeira esteja atuando como reserva cognitiva, retardando o impacto do envelhecimento.

Quanto mais subsídios se tiver sobre o processo de envelhecimento saudável, mais possibilidades teremos de evitar futuras demências, como também prevenir problemas cognitivos de demência neuronal e falta de cognição. Nessa faixa etária, os envelhescentes e pessoas da terceira idade apresentam menor velocidade de processamento da informação e precisam de maior disponibilidade de tempo para leitura e escrita em sala de aula, mas não impede que eles se motivem a reativar os neurônios e manter a sua cognição em equilíbrio. 


\subsubsection{Leitura, cognição e envelhecimento}

No envelhecimento, algumas evidências começam a surgir como a falta da acuidade visual, perda auditiva, demora para responder algumas perguntas, mas esses sinais evidentes são previstos para todos os envelhescentes. E, ainda que alguns traços de senilidade estejam presentes, como a falta de acuidade visual, as pessoas mais velhas demonstram interesse em permanecer com a habilidade de leitura, que é uma habilidade essencial para os envelhescentes e pessoas de terceira idade se manterem ativos socialmente no mundo letrado.

A leitura é uma atividade cognitivamente estimulante, pois o leitor passa a adquirir novas informações e ativar o cérebro continuamente. Nesse processo, os envelhescentes e pessoas da terceira idade exercitam, assim, as áreas neurocorticais, evitando as demências e ou perdas neurodegenerativas.

Assumimos a concepção de leitura proposta por Goodman (1967), para quem o leitor recodifica a codificação gráfica da fonética da língua, afirmando que o significado da palavra não é a parte principal da leitura a ser verbalizado oralmente, afirmando ainda ser possível essa verbalização, mas sem compreensão e que só poderá haver a compreensão da escrita do texto, se houver uma análise da decodificação da semântica da língua. (GOODMAN, 1967) ${ }^{8}$. No entanto, é possível que o leitor consiga efetuar dois procedimentos de leitura em dupla rota.

Do ponto de vista fisiológico, a leitura envolve diferentes estágios para o processamento da informação, com a transformação das informações recebidas pela visão e sistema de memória fonológica, até que sejam concluídas as compreensões do sistema semântico e sua finalização (LA BERGE; SAMUELS, 1974). Esses estágios envolvem dois níveis: acurácia e automaticidade.

No primeiro nível, denominado de acurácia, é necessário que o leitor esteja atento e concentrado para processar a compreensão da leitura. Já no nível de automaticidade, não se exige tanto a memória e a sua atenção por ser um processo de respostas automáticas em relação às perguntas recebidas; o leitor faz a leitura em um procedimento experimental e discorre as informações pelas tarefas adquiridas em dissociação.

A aquisição da decodificação das várias tarefas a serem feitas, leva-se muitos anos em que muitas pessoas não conseguem obter a fluência de

\footnotetext{
${ }^{8}$ No Brasil, a concepção de leitura de Goodman (1967) é replicada nos trabalhos de Leffa (1996), dentre outros.
} 
um leitor fluente, mas mesmo assim, os leitores conseguem compreender melhor o desempenho de uma fala com facilidade e rapidez. (LA BERGE; SAMUELS, 1974, tradução nossa) ${ }^{9}$

Durante a realização de uma tarefa cognitivamente complexa, como é a leitura, é necessário que sejam coordenados muitos componentes dos processos em um período curto de tempo. Se cada processo do componente da leitura necessitar de atenção, os desempenhos das tarefas complexas serão impossíveis de serem alcançadas. Mas se os componentes dessas tarefas forem ajustados, elas poderão ser processadas automaticamente, por isso os níveis de acurácia e automaticidade. Para chegar ao nível de automaticidade, é preciso ter consciência dos processos físiológicos envolvidos na leitura.

Dehaene (2012) releva a importância da fisiologia da mecânica humana da leitura. A leitura começa pelos olhos, mais especificamente pela retina, que é a responsável pela projeção dos fótons reenviados ao córtex cerebral através da fóvea, região central da retina. A fóvea corresponde a apenas $15^{\circ}$ do campo visual e é responsável pela captura da leitura, e, por sua característica estreita, faz com que os olhos se movam incessantemente no curso da leitura. A parafóvea corresponde ao ponto de fixação, em $5^{\circ}$ do padrão normal, e a região de fixação da leitura vai além da parafóvea (DEHAENE, 2012).

Os olhos fazem movimentos discretos e contínuos para captar a informação visual, o que corresponde à capacidade de decodificar entre quatro a cinco palavras por segundo. Por conta do grau de acuidade da fóvea e parafóvea, à medida que o campo leitor se afasta do centro do olhar, pode haver uma perda de codificação visual.

No nosso sistema de leitura do português, lemos da esquerda para a direita. $\mathrm{O}$ movimento captor ocular percorre as frases em sacadas (ou movimento sacádico), movimentos muito curtos e rápidos, que duram em torno de 30 a $50 \mathrm{~ms}$. As sacadas oculares correspondem ao número de letras percorridas no texto que podem ser variadas de acordo com o estilo da escrita. O número de caracteres que podemos executar em uma leitura é de aproximadamente entre sete e nove letras a cada sacada.

Nas fixações, os olhos fixam, com pausas entre sacadas; e duram em média de 200 a $250 \mathrm{~ms}$. Nesse processo de sacadas e fixações, nem sempre o olhar segue palavra por palavra; Deheane (2012) afirma que palavras gramaticais, como verbos auxiliares,

\footnotetext{
9 “[...] The acquisition of the Reading skill takes years, and there are many who do not succeed in becoming fluent reader, even though they may have quickly and easily mastered the skill of understanding speech."
} 
pronomes, conjunções, preposições ou artigos, são quase sempre puladas, e que as outras palavras essenciais de conteúdo, tais como nomes, verbos, adjetivos, advérbios, costumam ser fixadas pelo olhar.

Além das sacadas e fixações, existem os movimentos de retorno de leitura, quando os olhos movem do final da linha horizontal para o início da anterior ou da próxima linha, e a regressão de leitura, caracterizada por movimentos da direita para a esquerda, para regiões anteriores do texto na mesma linha ou para linhas anteriores (RAYNER; JUHASZ; POLLATSEK, 1998).

Leitores hábeis, ou no nível da automaticidade, fazem fixações mais curtas, sacadas mais longas, e menos regressões do que os leitores menos habilidosos, ou no nível da acurácia. Quando se trata de aprender a ler em uma língua estrangeira, é preciso ter o conhecimento gramatical para atingir a automaticidade nas fixações.

Ao traçarmos uma abordagem fisiológica da leitura, temos que considerar também os efeitos do envelhecimento nesse processo. O tempo de formação de um leitor é muito longo, o que equivale ao amadurecimento desde a primeira fase de criança, na alfabetização, até a adolescência, ao final da qual a estrutura corpórea fisiológica está amadurecida e o circuito neural está formado para executar todos os procedimentos de processamento de informação (LENT, 2005; DEHAENE, 2012).

Com o passar do tempo, as pessoas, de maneira geral, diminuem os ritmos de tarefas em todos os sentidos. Fisiologicamente, os músculos estão mais enrijecidos e tudo que fazemos é mais demorado. Na leitura, por exemplo, a retina está mais rígida, e com isso, a leitura, ao avançar da idade, começa a ficar mais lenta.

O monitoramento da leitura do movimento ocular propicia mensurar o tempo de duração das fixações e do movimento de retorno. Os olhos deslizam sempre da esquerda para a direita sobre o procedimento de leitura; na sacada, capturamos entre 7-9 caracteres; as pausas são sempre feitas e chamadas de fixações, as quais são sempre lidas e 200-250 ms, para leitura silenciosa, já na leitura em voz alta, o leitor executa as fixações em 275 ms, para os leitores hábeis (RAYNER, CHACE, SLATTERY, ASHBY, 1998, p. 241 242). Como podemos ver, existe diferença entre a leitura em voz alta e a leitura silenciosa. Segundo Luegi, Costa e Faria (2006), a duração média das fixações na leitura silenciosa é de 250 ms, mesmo padrão estabelecido por Rayner et al. (1998), baseada no grau de dificuldades do leitor em relação a palavras isoladas ou frases. Em leitura em voz alta, os valores são modificados de acordo com os experimentos. A partir de experimento com a leitura de 2 textos por 20 participantes, as autoras identificaram os seguintes parâmetros: 
leitura em voz silenciosa $=225 \mathrm{~ms}$; e leitura em voz alta $=275 \mathrm{~ms}$. Esses dados se referem ao tempo de duração das fixações na leitura de textos em português de Portugal, aferidos pelo eye tracker 504 ASL scan path (LUEGI, COSTA, FARIA, 2006 p. 9).

Obter esse tipo de detalhamento sobre o processamento da leitura é importante para o planejamento de cursos e elaboração de materiais didáticos, a exemplo de ensinar uma língua estrangeira para envelhescentes e pessoas da terceira idade.

\subsection{O TEMPO NA AULA DE INGLÊS}

Para verificar os efeitos do tempo cognitivo e do tempo social nas aulas de inglês, foram desenvolvidos três estudos: um estudo de leitura, um estudo sobre a organização do curso e um estudo de estados emocionais dos participantes. O primeiro estudo tem relação mais direta com o tempo cognitivo; os outros dois envolvem tanto o tempo cognitivo quanto o tempo social.

No estudo de leitura, quanto ao tempo, espera-se que os participantes sejam mais rápidos na leitura de textos em português do que em inglês, e também sejam mais rápidos na leitura silenciosa do que em voz alta. Quanto aos grupos experimentais, espera-se que os participantes mais jovens demandem menos tempo do que os participantes envelhescentes, que, por sua vez, demandem menos tempo do que os participantes idosos na execução dessas tarefas.

Quanto ao número de fixações na leitura, espera-se que os participantes do grupo experimental dos mais jovens façam menos fixações (com sacadas mais longas) do que os participantes envelhescentes, que, por sua vez, façam menos fixações do que os participantes idosos, em função das limitações fisiológicas do envelhecimento (enrijecimento da musculatura).

No estudo da organização do curso, relacionado ao tempo planejado e ao tempo executado de cada aula, considerando as evidências apontadas na literatura em relação à execução de tarefas e o dispêndio de tempo por parte dos idosos, espera-se que as aulas demandem mais tempo do que o planejado. Para identificar em que momentos há maior demanda de tempo, as aulas foram segmentadas em atividades e o tempo foi aferido para cada uma das atividades.

E, no estudo das emoções, foi desenvolvido um teste com fichas emocionais, que, considerando tratar-se de um curso livre, para participantes que não são obrigados a frequentá-lo (diferentemente de um público da faixa etária de escolarização obrigatória, 
por exemplo), espera-se que o estado emocional predominante seja positivo; o controle das emoções na entrada e na saída visa a identificar se o curso instiga mudanças emocionais em seus participantes.

O detalhamento dos estudos será apresentado na seção a seguir, assim como a apresentação do lócus do estudo: um curso de extensão de inglês para envelhescentes e pessoas de terceira idade. 


\section{ESTUDO SOBRE O ENSINO DE INGLÊS PARA ENVELHESCENTES E PESSOAS DE TERCEIRA IDADE}

Depois de evidenciarmos a mudança na percepção e na motivação de envelhescentes e pessoas da terceira idade nos dias de hoje, especialmente no que diz respeito ao aprendizado de uma língua estrangeira, e relevarmos a importância da formação de professores de língua inglesa para atuarem com esse perfil de público, dado que ainda inexistem ações formativas nos cursos de licenciatura para atuarem com as especificidades demandadas por envelhescentes e pessoas da terceira idade, este capítulo apresenta os procedimentos metodológicos para a análise de efeitos de tempo social e tempo cognitivo na situação de aula de língua inglesa para envelhescentes e pessoas de terceira idade.

Inicialmente, apresentamos o lócus da ação de pesquisa, o curso de extensão "A Aula de Inglês para a Terceira Idade". Escolhemos trabalhar com um curso de extensão a partir da experiência de Villani (2007). Em seguida, serão detalhados os estudos realizados para aferir os efeitos de tempo social e de tempo cognitivo com esse tipo de público, cujas hipóteses foram apresentadas na seção anterior.

\subsection{PROJETO DE EXTENSÃO “A AULA DE INGLÊS PARA A TERCEIRA IDADE"}

Fomentado pela Pró-Reitoria de Extensão (Proex), via Programa Institucional de Iniciação à Extensão (Pibix), o projeto de extensão "A Aula de Inglês para a Terceira Idade" (PORTO, 2012) tem como objetivo, além de preparar o discente da Universidade Federal de Sergipe para atuar com o público de pessoas da terceira idade, oportunizar à comunidade um curso de língua inglesa gratuito voltado para o público acima de 45 anos de idade, integrando alunos envelhescentes e da terceira idade da comunidade com alunos do curso de graduação em Letras Inglês da Universidade Federal de Sergipe, a fim de experienciar metodologias e aprendizagens da língua inglesa para esse público específico.

No curso, os participantes são levados a conhecer a estrutura básica da língua inglesa e também a exercitar as demais habilidades linguísticas (ouvir, falar, ler, escrever), a aprender a se comunicar, ainda que de forma limitada em textos situacionais, 
para poderem assim proceder em viagens e em outros objetivos pessoais com o uso da língua em questão.

Mais especificamente, a ação de extensão tem os seguintes objetivos:

- Possibilitar a formação didático-pedagógica dos alunos dos cursos de graduação em Letras Português-Inglês/Letras-Inglês, objetivando a sua prática como docente consciente de uma nova situação demográfica idosa e atuante.

- Aprimorar o uso das habilidades linguísticas através dos conteúdos ministrados.

- Aplicar materiais e técnicas que se adequem às necessidades dos participantes da terceira idade, sendo adicionados novos recursos didáticos pedagógicos diante das prováveis situações, isto é, as ações desenvolvidas no projeto de extensão partem de abordagens já existentes, mas com adequações ao público atendido.

O ponto de partida foram atividades de leitura de textos na linha de inglês instrumental, isto é, textos situacionais, autênticos e objetivos, por entendermos ser uma atividade social, que pode proporcionar, inicialmente, uma ação motivadora, além de role-plays, momento em que envelhescentes e pessoas da terceira idade verbalizam os textos situacionais estudados que favorecem a sociabilização e compartilham as suas experiências do cotidiano.

O aluno participante não tem a obrigatoriedade de cumprir todo o programa em cada módulo, mas, mesmo assim, seguimos os conteúdos desde o nível básico inicial ao intermediário, baseados na sequência de instrução sobre as normas de ensino. O curso é também um espaço de convívio social: em todas as aulas há um coffee-break, oportunidade em que alunos e professores conversam, trocam ideias, falam na língua estrangeira, o que promove a ressignificação da vida de todos os envelhescentes e pessoas da terceira idade.

A metodologia desenvolvida no curso de extensão é por meio de tentativas e acertos com um grupo colaborativo, isto é, as aulas são previamente programadas em encontros frequentes com os membros da equipe (voluntários, bolsistas e membros externos), orientados pela coordenadora do projeto. Uma vez aplicados métodos e técnicas no ensino da língua inglesa, observa-se se o objetivo das aulas foi alcançado ou não, ratificando a repetição das ações positivas (para os acertos) e retificando as negativas (para os erros). 


\subsubsection{Histórico}

O projeto de extensão "A Aula de Inglês para a Terceira Idade" está em desenvolvimento desde 2011 (já na sétima edição). No primeiro período de implementação, em agosto de 2011, o projeto foi contemplado pelo programa Pibix com dois alunos bolsistas e foi ofertado, desde o primeiro momento, para duas turmas: Turma 1, com aulas nas segundas e quartas-feiras e Turma 2, com aulas apenas nas sextas-feiras.

Nos segundo e terceiro períodos do curso, em 2012, o projeto foi contemplado novamente pelo Pibix, mas agora, além de dois bolsistas, um voluntário também participou. Nos quarto e quinto períodos do curso de extensão (2013), o projeto foi contemplado pelo Pibix apenas com um bolsista, mas continuou contando com um voluntário. Nos sexto e sétimo períodos do curso de extensão (2014), novamente o projeto foi contemplado pelo Pibix com um bolsista e contou com três voluntários. Nos oitavo e nono períodos (2015), o projeto contou com sete participantes: um aluno bolsista do Pibix, quatro voluntários e dois membros externos egressos do curso de Letras Inglês que se mostraram interessados em aprender como ensinar a esse público.

Nos décimo e décimo primeiro períodos (2016), momento em que foram coletados os dados e desenvolvidos os experimentos que serão apresentados mais à frente, o projeto contou com oito alunos envolvidos: dois bolsistas do Pibix, quatro alunos voluntários e novamente dois membros externos. Após uma nova solicitação, o projeto foi contemplado com mais uma cota de bolsa Pibix e um dos voluntários passou a ser bolsista.

Nos décimo segundo e décimo terceiro períodos (2017), o projeto teve seis alunos envolvidos: um bolsista do Pibix, três alunos voluntários e dois membros externos, que ainda estão atuando até o momento.

Todos os bolsistas e membros externos participantes do projeto passaram por treinamento prévio para se familiarizarem com os diferentes tipos de metodologia a serem aplicados no curso de extensão, bem como, para terem orientações sobre como conduzir as aulas. Na preparação do início das aulas, foram elaborados os cronogramas de aula, com os conteúdos a serem ensinados de forma indutiva, isto é, por meio de leituras de textos situacionais sobre temas do dia-a-dia, facilitando a motivação e a discussão dos textos entre os alunos.

Durante todo esse período, as turmas 1 e 2 continuam as mesmas, com alguma rotatividade de participantes. É importante destacar que, embora o fomento proporcionado pelo Pibix tenha diminuído (não só para esse projeto, mas no contexto 
geral da universidade), aumentou o interesse de participantes voluntários e membros externos, o que demonstra a preocupação crescente de se qualificar para atender a esse tipo de público específico.

\subsubsection{Infraestrutura}

Considerando a infraestrutura de transporte urbano precária, traduzindo-se em limitações de locomoção dos participantes do projeto até o Campus Universitário José Aloísio de Campos/UFS, sediado no município de São Cristóvão, e considerando ainda que a maioria dos participantes do curso residem no município de Aracaju, o público alvo sugeriu que as aulas, preferencialmente, fossem ministradas no Centro de Cultura e Arte (Cultart), vinculado à Pró-Reitoria de Extensão (Proex). Esse espaço, que está situado no centro de Aracaju, conta com boa acessibilidade por parte do transporte público.

\subsubsection{Material didático}

Até o momento, não existe um material didático comercial desenvolvido especificamente para esse tipo de público, que, como vimos, têm demandas e experiências de vida diferentes de outros públicos. Por isso, o material adotado no curso de extensão foi escolhido a partir de outros já existentes.

Nos primeiro e segundo períodos, para facilitar a leitura do público alvo, foram utilizadas cópias ampliadas dos seguintes materiais (a ilustração das capas dos materiais utilizados pode ser vista na figura 1):

- AMORIM, J. O.; SZABÒ, A. Gramática Escolar da Língua Inglesa. São Paulo: Pearson-Longman, 2004. 317 p. com exercícios e respostas.

- MURPHY, R. Essential Grammar in Use - A self study reference and practice book for elementar students of English - With Answers. Cambridge: Cambridge University Press, 2008. 300 p.

- FIGUEIREDO, L. C.; SILVEIRA, M. F. English for travelers. São Paulo: Ática, 2009.

- UR, P.; WRIGHT, A. Five-minute activities: a resource book of short activities. Cambridge: Cambridge University Press, 1992. 
Figura 1: Material didático adotado no curso de extensão $-1^{\circ}$ e $2^{\circ}$ períodos.
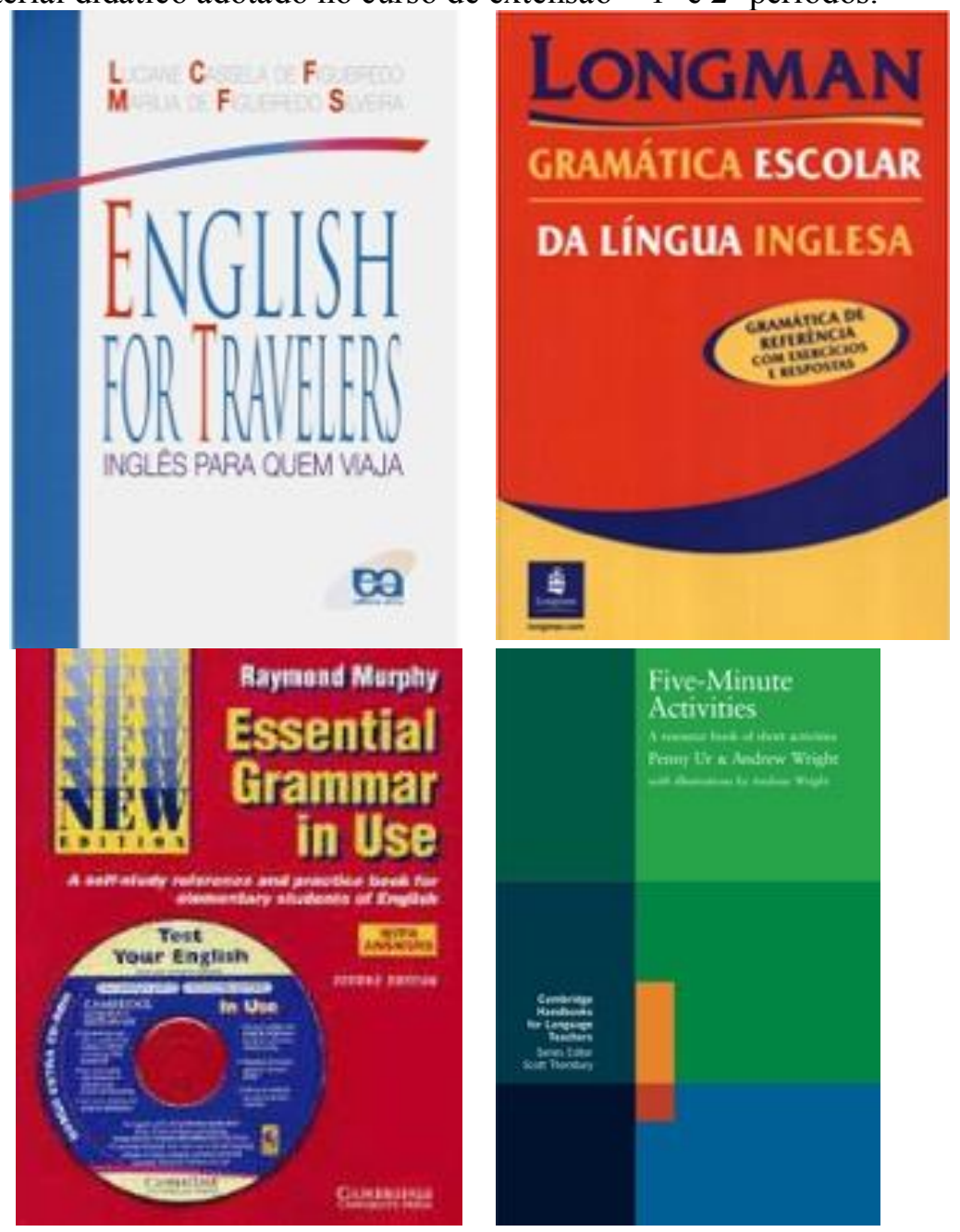

Além desses materiais, também foi utilizado dicionário de uso pessoal dos alunos.

Nos terceiros e quartos períodos do curso de extensão, foram utilizadas apenas cópias ampliadas do material que segue (ilustração da capa na figura 2):

- REVELL, R.; STOTT, T. Highly Recomended, Student's Book: English for The Hotel and Catering Industry. 2nd ed. Oxford- Oxford Press, 1994. 
Figura 2: Material didático adotado no curso de extensão $-3^{\circ}$ e $4^{\circ}$ períodos.

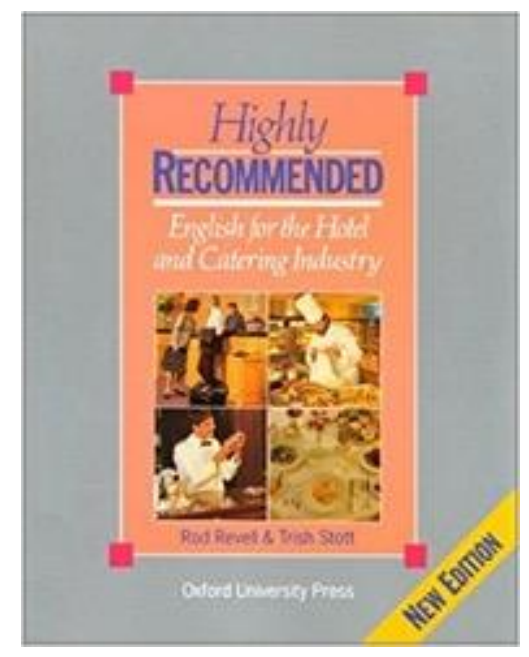

Os aprendizes de uma língua estrangeira podem ser motivados a fazer as leituras destas duas formas: primeiro faz-se uma leitura silenciosa, pensando como as palavras devem ser pronunciadas, e depois em voz alta, verbalizando as palavras, as frases, o texto, a fim de compreender o processamento da informação (COLTHEART, 2013). Foi assim que os audio-texts do livro Highly Recommended foram experienciados pelos alunos nos $3^{\circ}$ e $4^{\circ}$ períodos: eles liam os textos em silencio e, após a leitura do ministrante, eles repetiam a leitura em voz alta. Entretanto, um aprendiz de uma língua estrangeira, além dessa técnica (dupla-rota), pode utilizar outros procedimentos diferenciados na sala de aula. $\mathrm{O}$ aluno que lê pode aprender a reproduzir os traços fonéticos da língua estrangeira e os sons diferenciados dessa língua, bem como desenvolver outras estratégias de aprendizagem. É preciso aprender a ler para aprender e praticar a língua estrangeira.

A partir do quinto período, iniciamos a utilização dos seguintes livros (ilustração das capas na figura 3):

- COOPERMAN, A.; LEFFRETS, G. Family Album, U.S.A. New York; Toronto: Prentice Hall College Div, 1991.

- SCHUMACHER, Cristina. Pílulas de Inglês - Vocabulário. 1 ed. Rio de Janeiro: Editora LTC, 2009.

- COQUETEL. Treine seu Inglês - Livro 7. Rio de Janeiro: Editora Ediouro / Nova Fronteira, 2014.

- LATHAN KOENIG, C.; OXENDEN, C. American English File - 3A. London: Oxford, 2008. 
Figura 3: Material didático adotado no curso de extensão $-5^{\mathrm{O}}$ período.

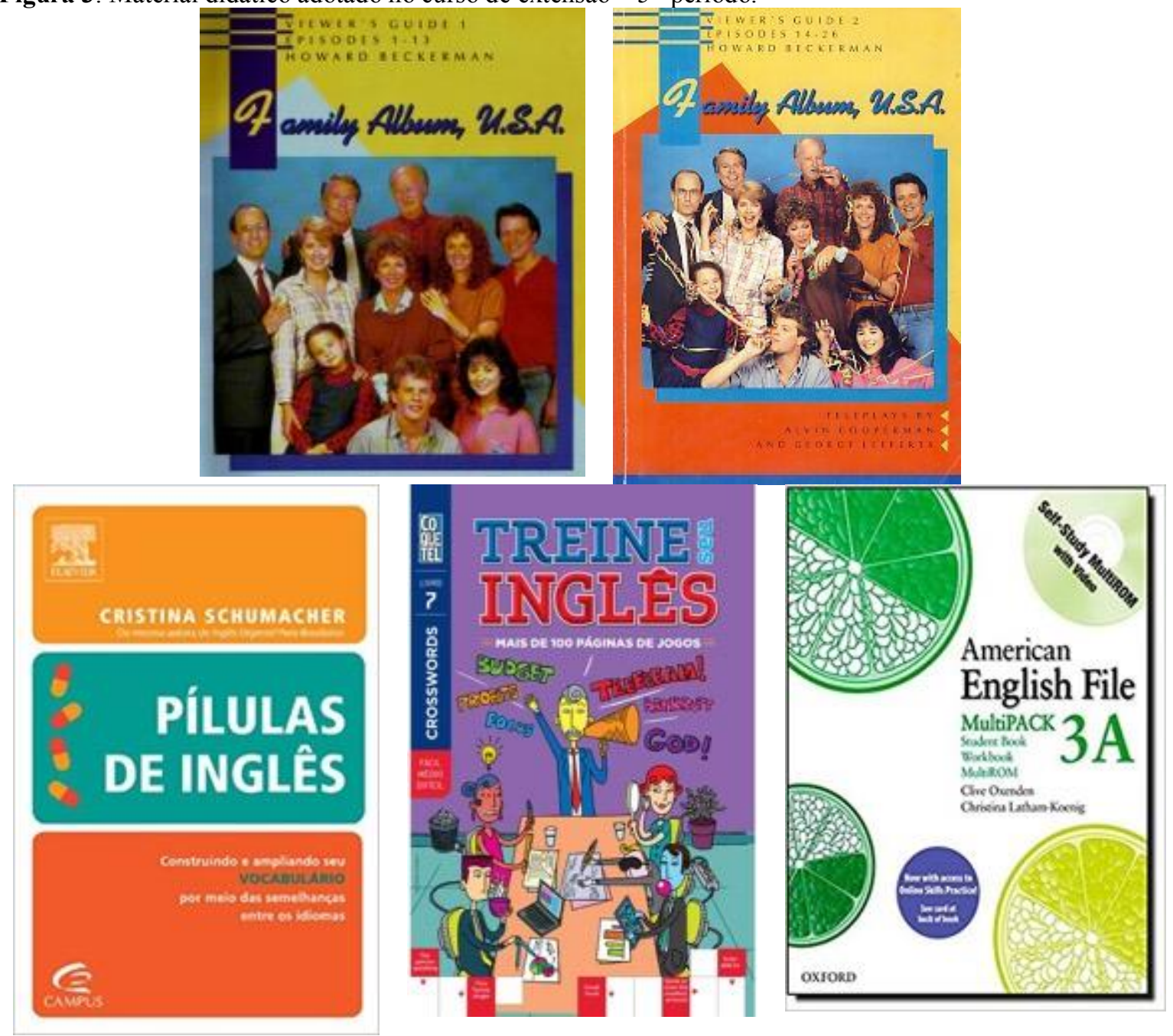

Destacamos aqui Family Album USA, de nível pré-intermediário, que possui dois volumes, pelo fato de os alunos do curso terem se identificado com as estórias narradas nessa coleção. São discutidas questões sobre a cultura americana e, nas discussões em sala, o assunto leva a identificar as diferenças existentes entre aquela cultura e a brasileira e outras culturas. O livro foi muito bem aceito devido às temáticas: é um álbum de família que retrata situações do cotidiano dos envelhescentes e sujeitos da terceira idade. É importante destacar que esse material didático foi adquirido por meio de verba do Departamento de Letras da Universidade Federal de Sergipe, em 1994, para uso do extinto Núcleo de Cultura Anglo Americano (Nucam). A Proex e o DLES colaboraram com as cópias do material didático para o curso de extensão.

Além desses materiais didático-pedagógicos, foram também utilizadas atividades extra, tais como: palavras-cruzadas, escritas de frases e ou diários, músicas, textos da internet que tratam de problemas atuais do dia-a-dia. As palavras-cruzadas são jogos 
usados em sala de aula que podem contribuir para a reativação de neurônios ao mesmo tempo em que traz ludicidade às diferentes estratégias de ensino-aprendizagem, motivando os alunos. O material didático English File foi utilizado nos experimentos dos textos em eye-tracking, apresentados na seção sobre procedimentos dos experimentos de leitura.

\subsection{DOCUMENTAÇÃO DAS AULAS DO CURSO DE EXTENSÃO}

Para a investigação dos efeitos do tempo social e do tempo cognitivo na aula de inglês para envelhescência e terceira idade, foram coletadas as documentações linguísticas das aulas do curso de extensão, com o objetivo de comparar o tempo de planejamento com o tempo de execução das aulas, bem como comparar o estado emocional dos participantes no início e no final da aula. A etapa de documentação das aulas e de coleta de dados foi realizada entre 02 de março de 2016 a 18 de junho de 2016, nas turmas 1 e 2 . O procedimento de coleta de dados para fins de pesquisa foi apreciado pelo CEP/CONEP, com CAAE 65725717.100005546, anexo 1.

O protocolo de documentação linguística das aulas foi adaptado a partir de Freitag $(2014,2017)$ e consistiu na execução dos seguintes procedimentos: inicialmente, os membros participantes do projeto tiverem treinamento para a coleta de dados de campo e documentação linguística, ministrado pela Professora Doutora Raquel Meister Ko. Freitag, em que foram enfocados os aspectos éticos e técnicos envolvidos no processo. Nesse treino, ficou definido o papel do ministrante da aula e o do documentador da aula. Assim, em cada aula, necessariamente, estariam presentes dois membros do projeto, um ministrante e um documentador, cada um com atribuições específicas.

O documentador é responsável pelo desenho da posição dos alunos em sala de aula (mapa de posicionamento em sala de aula, anexo 2), pelo acompanhamento da gravação em áudio das aulas e pela distribuição e recolhimento dos instrumentos de coleta de dados (fichas emocionais, anexo 3). Além disso, o documentador deve preencher a ficha de acompanhamento da aula, indicando quando a aula iniciou e quando a aula acabou, bem como o tempo de cada uma das partes do planejamento da aula (ficha de acompanhamento de aula, anexo 4). O documentador deve posicionar os equipamentos de gravação e ser responsável por seu acionamento.

O ministrante é responsável pela execução do plano de aula e pela instrução dos procedimentos para as fichas emocionais. Ao final, o ministrante deve preencher um 
relatório (relatório do ministrante, anexo 5), em que são relatadas intercorrências nas aulas, que posteriormente podem auxiliar no desvelamento de efeitos nos tempos de execução e planejamento.

Freitag (2017) destaca os aspectos éticos envolvidos no processo de documentação linguística para pesquisa, que são essenciais para o êxito não só do processo de documentação para fins de pesquisa, mas também para o êxito pedagógico dos alunos da envelhescência e terceira idade. Os papéis de ministrante e pesquisador precisam ser claramente definidos e respeitados pelos membros da equipe. O ministrante é responsável pela execução das aulas e não está sendo avaliado pela aula. O foco de interesse da documentação é a testagem de uma metodologia e não o desempenho do ministrante. $\mathrm{O}$ documentador precisa se inserir previamente na turma, para não causar estranhamento e dispersar os alunos, minimizando efeitos do paradoxo do observador. $\mathrm{O}$ documentador não deve interferir na aula do ministrante, seja para corrigi-lo, seja para auxiliá-lo, pois o foco de interesse da documentação, como já dissemos, é a metodologia empregada. Esse procedimento de coleta de dados desenvolvido por Freitag $(2014,2017)$ vêm sendo adotado em outros trabalhos que envolvem sala de aula, como no Profletras (ROCHA, 2016; ROCHA, 2018).

Após a documentação linguística, os áudios foram transcritos e serviram de suporte à análise das fichas emocionais e do tempo planejado e tempo executado, descritos a seguir.

\subsubsection{Fichas emocionais}

As questões fisiológicas interferem na evolução do envelhecimento em relação às perdas neurodegenerativas naturais de todo ser humano e as sensações individuais que podem refletir nas emoções internamente, podendo ser expressas emocionalmente de maneira verbal, escrita, ou testes emocionais, que utilizamos no curso de extensão.

Segundo Gondim, Loiola e Borges-Andrade (2015, p. 23), “os sentimentos estão relacionados a aspectos cognitivos e à interpretação subjetiva da situação, que relaciona o humor ao estado afetivo duradouro capaz de reverberar no modo como a pessoa age em

situações diversas [...]”. O estudo das emoções envolve a sensação, a físiologia, o comportamento, a avaliação e a cognição. Na abordagem das sensações, as emoções se referem ao que se sente internamente e se traduz em uma expressão emocional. 
O repertório de emoções humanas, no entanto, não se esgota nas emoções básicas que possuem relativa correspondência com as expressões faciais. Há um conjunto mais amplo de estados afetivos não tão visíveis, mas que interferem nas relações humanas. (GONDIM; LOIOLA; BORGES-ANDRADE, 2015, p. 24)

Visando a verificar se as aulas do curso de extensão "A Aula de Inglês para a Terceira Idade" apresentam efeitos no comportamento dos seus alunos envelhescentes e da terceira idade, foi realizada uma coleta de dados com a aplicação de instrumentos denominados fichas emocionais (anexo 3). Foram aplicados cinco modelos de testes emocionais de entrada, no início das aulas e na saída das aulas; isto é, os alunos recebiam as fichas com opções de escolha, marcavam com pintura em lápis de cor e escreviam em linhas abertas as suas justificativas de escolhas, positivas e ou negativas, como também justificavam as respostas anteriores na saída das aulas confirmando ou retificando as escolhas do início das aulas.

Gondim, Loiola e Borges-Andrade (2015) evidenciam a carência de abordagens na área educacional que relacionem emoções e sua interação com recursos didáticopedagógicos. As motivações podem ser promovidas pelos comportamentos profissionais sobre as nossas ações, que, na educação, por exemplo, podem ser aferidas pela transmissão de informação e do treinamento específico de habilidades. A educação está relacionada ao aspecto moral do ministrante ou dirigente da comunidade. Os pontos de vista envolvem discussão, diálogos e uma decisão sobre como resolver algum aspecto que necessite de uma opinião em comum a ser resolvida entre os grupos de trabalho para motivar e sustentar uma posição de interação entre os grupos.

\footnotetext{
A motivação é o sucesso adquirido sobre o conhecimento da língua. Devemos elaborar o material que tenha variedade de temas e funções gramaticais, ser autêntico, e que contenha interesse motivacional para o aprendizado do aprendiz. ${ }^{10}$ (CUNNINGSWORTH, 1984, p. 63, tradução adaptada nossa)
}

Vejamos os modelos dos testes presentes nas fichas emocionais, a seguir:

\footnotetext{
10 "Motivation is a major factor in language-learning success. We should look for material that has variety and pace, is of genuine interest to the learners and contains learning activities that will appeal to them. Activities which encourage personal involvement tend to increase motivation. The cultural stand point of the course material is also important and should match as far as possible the objectives of the learner." (CUNNINGSWORTH, 1984, p. 63)
} 
Figura 4: Teste emocional 1
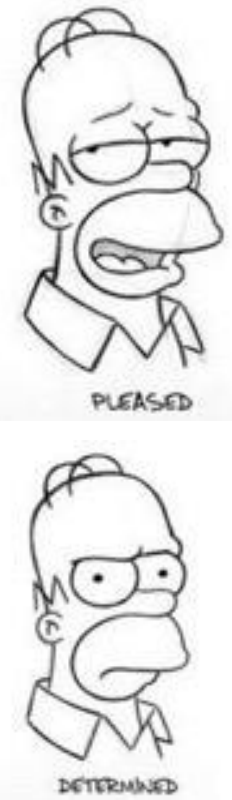
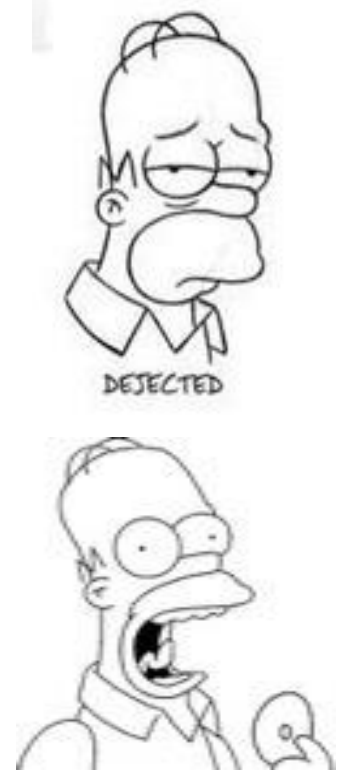

Hungry

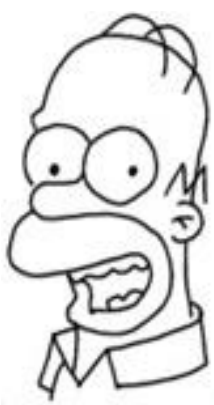

Happy

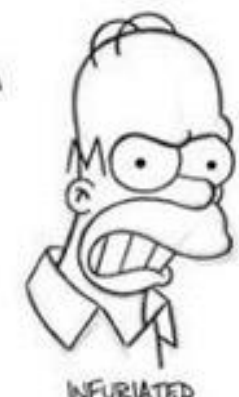
$\underline{371104385}$

Fonte: $\quad$ https:/www.shutterstock.com/pt/image-vector/set-vector-valentines-day-smiles-

No modelo do teste emocional 1, por exemplo, os participantes poderiam responder HAPPY ou DETERMINED, se se sentissem positivamente motivados, ou DEJECTED ou INFURIATED, se estivessem negativamente motivados.

Figura 5: Teste emocional 2

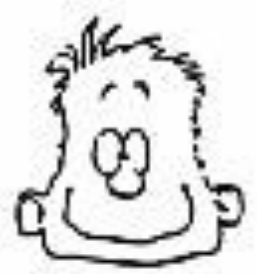

HAPPY

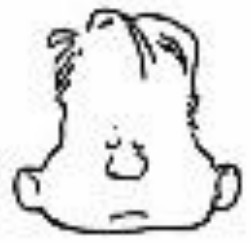

ASHAMED

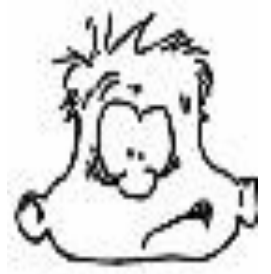

ANXIOUS

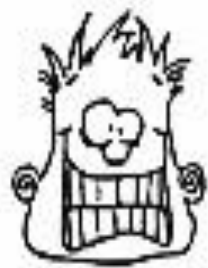

ECSTATIC

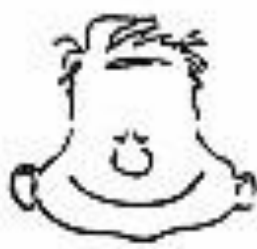

CONFIDENT

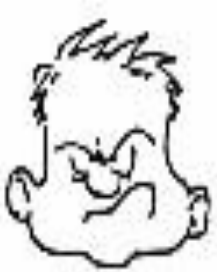

ANGRY

Fonte: http://tutorschoolfrench.wordpress.com/category/grammar-notes/

No modelo do teste emocional 2, os participantes poderiam responder HAPPY ou CONFIDENT, se estivessem positivamente motivados, ou ANXIOUS ou ASHAMED, se estivessem negativamente motivados. 
Figura 6: Teste emocional 3.
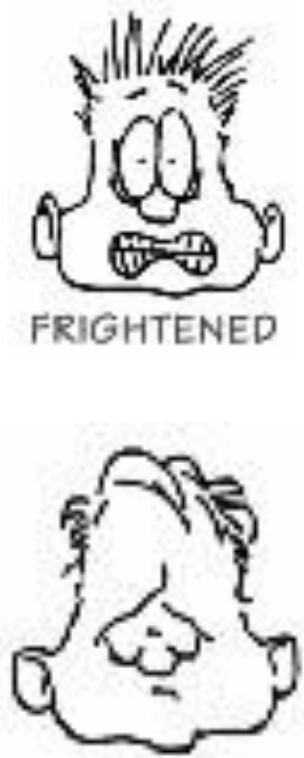

LONELY

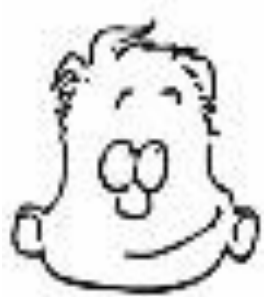

HOPEFUL

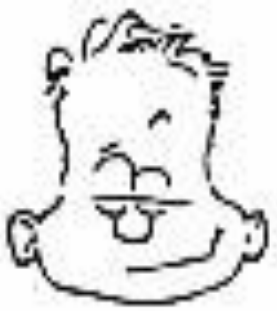

SMUG

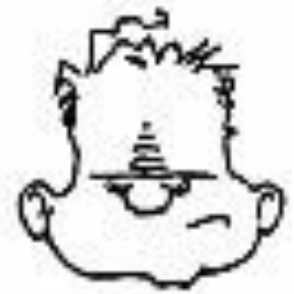

FRUSTRATED

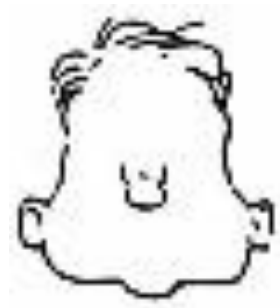

SHY

Fonte: http://tutorschoolfrench.wordpress.com/category/grammar-notes/

No modelo do teste emocional 3, os participantes poderiam responder HOPEFUL se estivessem positivamente motivados, ou qualquer outra resposta, se estivessem negativamente motivados.

Figura 7: Teste emocional 4

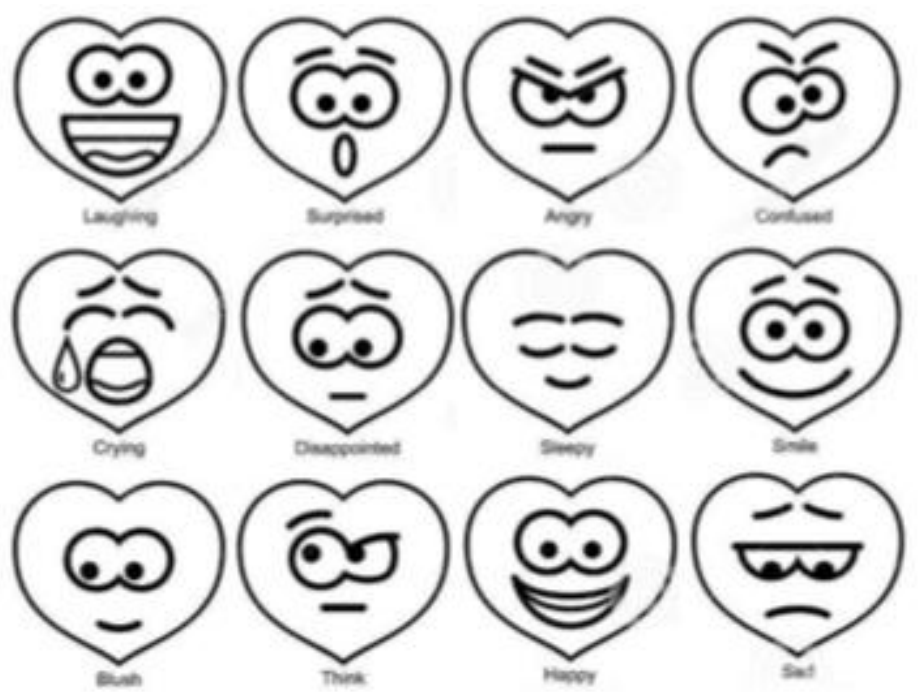

Fonte: https://www.shutterstock.com/pt/image-vector/set-vector-valentines-day-smiles-371104385

No modelo do teste emocional 4, os participantes poderiam responder, por exemplo, HAPPY ou SMILE, se estivessem positivamente motivados, ou CONFUSED ou $S A D$, se estivessem negativamente motivados. 
Figura 8: Teste emocional 5

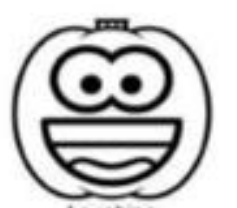

Lavghing

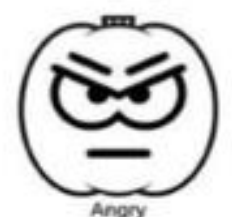

Angry

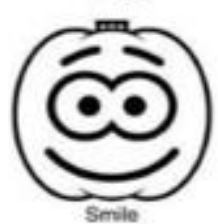

Fonte: https://www.123rf.com/photo 43668454 stock-vector-set-vector-halloween-smileys.html
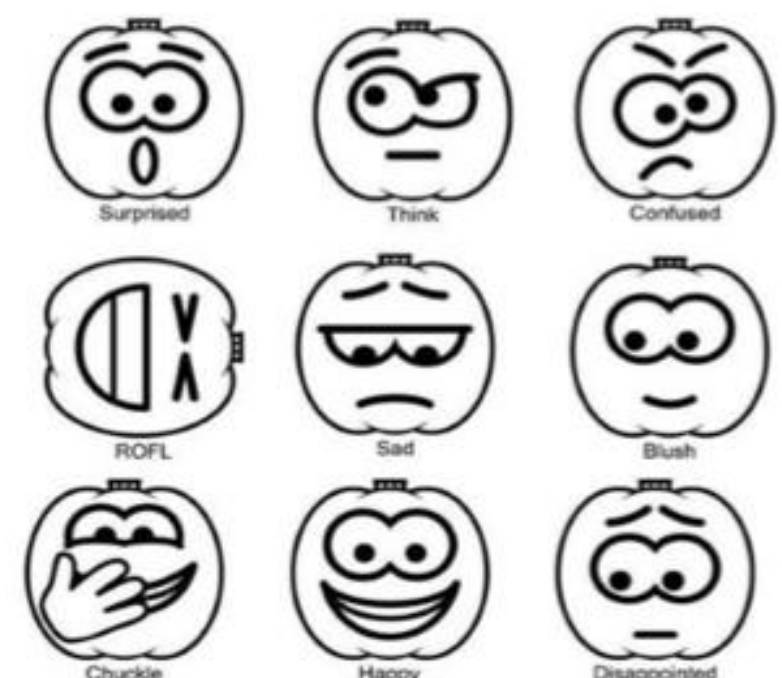

Hagpy

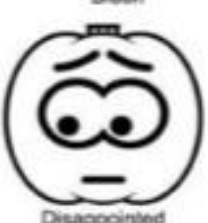

E, por fim, no modelo do teste emocional 5, os participantes poderiam responder, por exemplo, HAPPY ou ROFL, se estivessem positivamente motivados, ou DISAPOINTED ou CONFUSED, se estivessem negativamente motivados. O objetivo da aplicação das fichas emocionais foi verificar se os envelhescentes e pessoas da terceira idade que participam do curso estão conscientes de uma ressignificação em suas vidas e se mudam seu estado emocional depois da aula da língua estrangeira. $\mathrm{O}$ teste emocional também é fundamental para diagnosticar se as ações didático-pedagógicas estão influenciando positiva ou negativamente os participantes.

Nas elaborações dos planejamentos das aulas, imaginamos que seria uma oportunidade de motivar o início das aulas de uma maneira diferente, descontraindo-os dos problemas externos, e, de certa forma, fazendo com que eles se concentrassem nas aulas. O lápis de cor também foi oferecido para que eles pintassem. Em relação à pintura e emoções, vale destacar que foram desenvolvidas atividades com cadernos de pintura (1. ${ }^{\circ}$ Volume, Jardim Secreto: Caça ao Tesouro Antiestresse, e o 2. ${ }^{\circ}$ volume, Floresta Encantada, de Johanna Basford), que, embora tenham sido desenvolvidos para crianças, podem ser utilizados por pessoas de todas as idades, com o objetivo de divertir e exercitar a mente, ativando as áreas da emoção, localizadas no lado direito do hemisfério cerebral, e ativando outras regiões do cérebro. Desenhos foram adaptados desse material e entregues aos alunos como atividade extra, para que fosse feita em casa, objetivando a estimular outras atividades de inglês na habilidade de escrita, para serem desenvolvidas em casa como forma de chamar a atenção e descontraí-los dos problemas externos. 


\subsubsection{Aula planejada e aula executada}

Como explicamos anteriormente, as aulas do décimo e décimo primeiro períodos do curso de extensão foram planejadas com o objetivo de ser medido o tempo efetivo de sua execução. Para isso, foi elaborado um instrumento para a verificação do tempo da elaboração das aulas e o tempo executado, em cada aula (ficha de acompanhamento de aula, anexo 4 e relatório do ministrante, anexo 5). Por hipótese, a partir da experiência nas práticas do curso desde a sua implementação, o tempo planejado para as aulas é sempre insuficiente para se concluir todo o roteiro dos cronogramas das aulas.

A cada aula, ministrante e documentador tinham instrumentos específicos para serem preenchidos, visando ao controle de tempo e das intercorrências nas aulas que foram previamente planejadas. Além disso, em cada aula, foi preenchido o mapa de classe (anexo 3), que tem como objetivo identificar os locais dos assentos que os alunos ocupam a cada aula e como eles interagem nas aulas e materiais didáticos, como também os locais específicos dos ministrantes e dos documentadores (anexo 2). Após a coleta, os dados de tempo de planejamento e tempo de execução foram tabulados e comparados.

\subsection{PROCEDIMENTOS PARA MEDIR TEMPO DE LEITURA}

Para mensurar o tempo de leitura, foi desenvolvido um experimento com três grupos de participantes: jovens, envelhescentes e pessoas da terceira idade. Os dois últimos grupos de participantes são os alunos do curso de extensão "A aula de inglês para a terceira idade".

O objetivo do experimento é mensurar o tempo de leitura em voz alta e silenciosa de textos em língua portuguesa e em língua inglesa, bem como medir o tempo e o número de fixações na leitura de textos curtos (cerca de 100 palavras) nas duas línguas.

O objeto do estudo está voltado para o processamento de leitura e como mensurar o tempo de uma leitura em milissegundos. Para isso, usamos o eye-tracker (rastreador ocular). Essa ferramenta serve para usos de pesquisas em leitura, experimentos, comparação com categorias diferentes de idade, gêneros humanos, medir o tempo de leitura, detectar questões da fonologia e fonética da língua a ser estudada, verificar também cognitivamente se o participante compreende a leitura com o objetivo proposto pelo pesquisador e quais objetivos foram propostos para poder comprovar cientificamente o desempenho dos participantes envolvidos. 
Assim como o nome sugere, o movimento ocular envolve o rastreamento dos movimentos dos olhos [...] no processamento de rastreamento, as câmeras monitoram os olhos e os computadores calculam para onde os olhos fixaram na tela (no campo visual) e por quanto tempo [...] É um método significativo porque, ao contrário de testes de acompanhamento (SPR), ele não traz uma resposta clara; o sujeito pesquisado é submetido ao teste para medir o potencial das emissões magnéticas e potencialidades do cérebro sem interferência externa (de forma bem natural); nos exames de Eletroencefalograma (ERPs) e Imagem de ressonância magnética - (FMRI), o rastreador ocular pode obter um teste de forma mais naturalista nas apresentações dos textos. O pesquisador pode apresentar um parágrafo ou frases na tela e gravar as estruturas de fixação e sacadas quando um leitor for executar a leitura. Claro, esse método não é completamente natural, os participantes em um estudo de rastreador-ocular, utilizando um protetor de cabeça que sustenta uma câmera, e um apoio de queixo com o objetivo de manter uma posição firme. Alguns tipos de rastreadores oculares, necessitam que o sujeito pesquisado morda uma barra protetora para manter a cabeça fixa em que as câmeras estão localizadas sobre a mesa bem próximo do sujeito pesquisado. (COWLES, 2011, p. 44-60, tradução nossa) $)^{11}$.

Para o rastreamento ocular, utiliza-se equipamento de eye-tracker, que, assim como o nome sugere, visa ao rastreamento dos movimentos dos olhos: no processamento de rastreamento, as câmeras monitoram os olhos e os computadores calculam para onde os olhos fixaram na tela (no campo visual) e por quanto tempo.

O equipamento utilizado é o EyeTribe, com frequência $60 \mathrm{hz}$, com o módulo "pygaze-init" do software Opensesame, para a medida de fixações na leitura silenciosa. O computador utilizado foi um desktop Dell Precision T 7600, com monitor de 27'. A leitura em voz alta foi registrada em áudio com o gravador digital portátil Zoom Handy Recorder.

\footnotetext{
11 "As the name suggests, eye-tracking involves tracking the movements of the eyes. [...] In eye-tracking, cameras monitor the eyes and then computers calculate where the eyes fixate on a visual display, and for how long. It's a great method because, unlike Self Paced Reading - (SPR), it requires no overt response[...] "online" measures like event-related brain potentials, Eletroencephalograms-(ERPs) and functional Magnetic Resonance Information-(fMRI), it can handle pretty naturalistic presentations of text. A researcher can, if he or she wants, just display a paragraph (or a single sentence) and record the pattern of fixations and saccades as someone reads it. Of course, this method is not completely naturalistic: participants in an eye-tracking study are likely to be wearing a headband that holds the cameras, or have to rest their head on a brace (or chin rest) in order to keep it steady. Some types of eye-trackers even require people to bite down on a "bite bar" to keep their head stable for cameras that are located on a table near the participant". (COWELS, 2011, p.44-60).
} 
Figura 9: Gravador utilizado para documentação das aulas

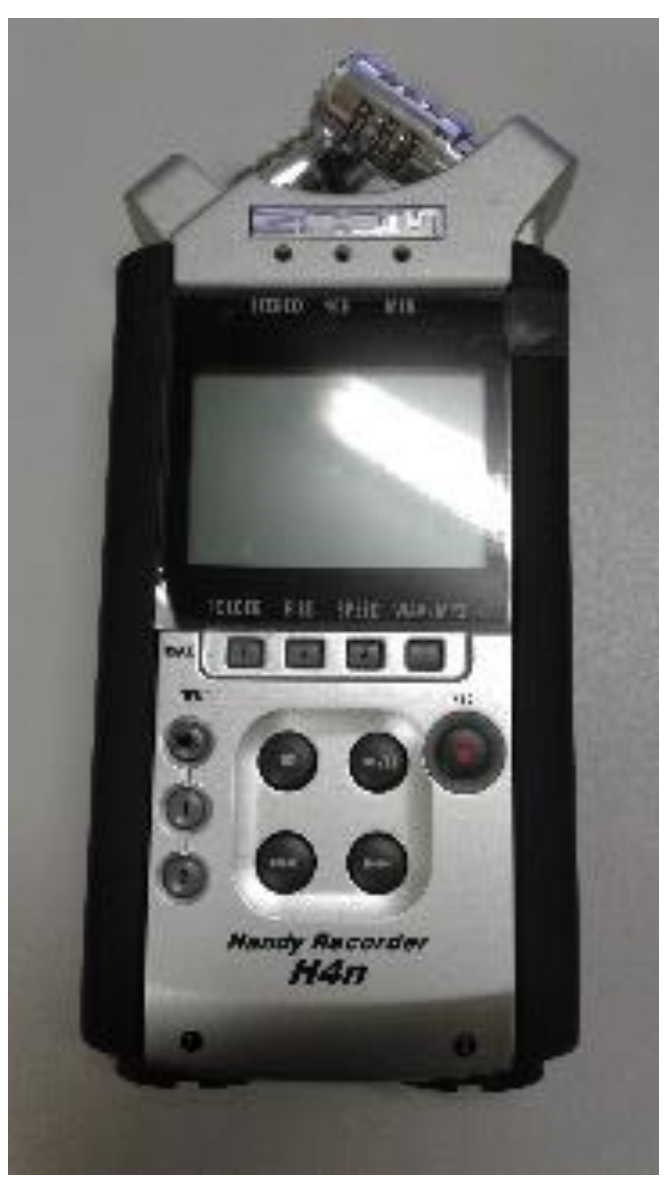

Eye-tracking (rastreador ocular) é um equipamento que tem permitido avanços no processo de estudos sobre o tempo de leitura. A figura 11 apresenta como o equipamento EyeTribe foi utilizado com os participantes que fizeram as leituras no Laboratório Multiusuário de Informática e Documentação (Lamid/UFS). 
Figura 10: Posicionamento do participante durante calibragem e experimento com eye-tracker

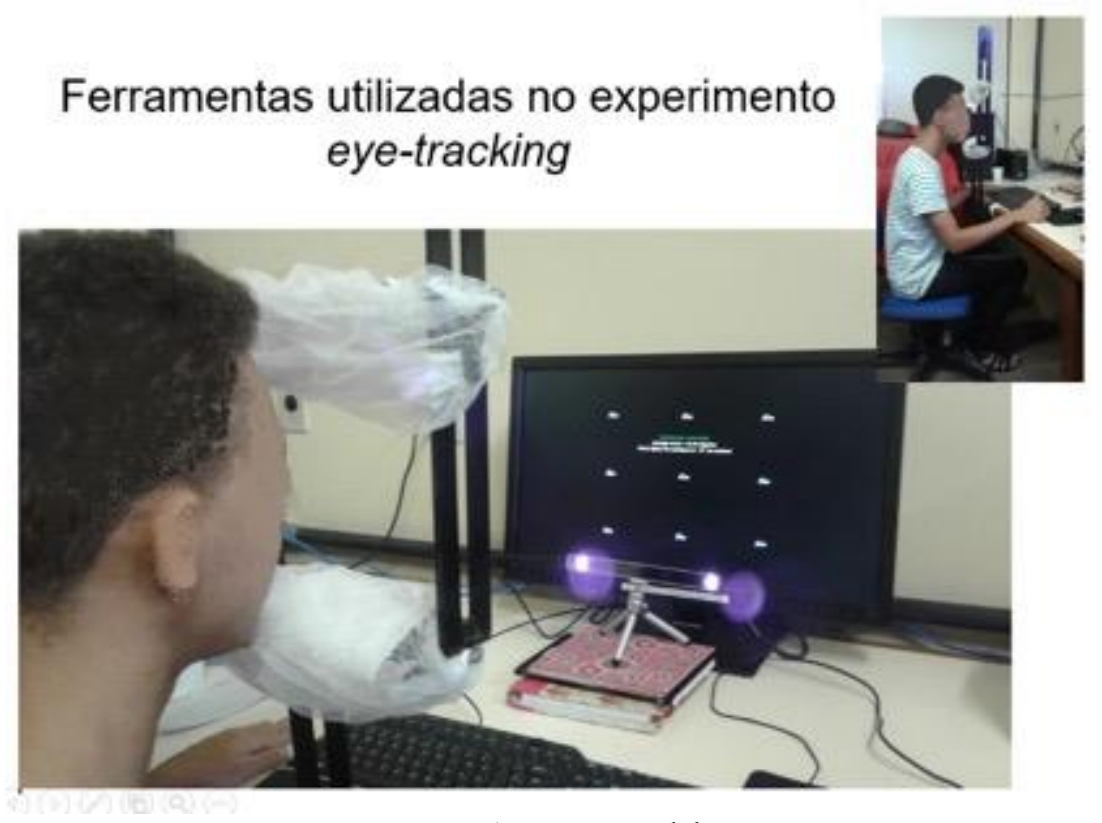

Fonte: Acervo pessoal da autora

Observa-se, na figura 11, que o aparelho de eye-tracker é conectado ao computador, e o participante apoia a cabeça em um suporte em barra de ferro com $1,40 \mathrm{~cm}$ de altura e $80 \mathrm{~cm}$ (aproximadamente) de distância do computador para apoiar a testa e o queixo, evitando a movimentação. As instruções foram passadas aos participantes em relação à postura e posição que o participante deveria assumir, e que não poderia mover nenhuma parte do corpo. Admitimos que pode haver um pouco de incômodo em ficar nessa posição. Depois de posicionado, o participante executa o procedimento de calibragem (ilustrado na figura 11). Após atingir grau adequado de calibragem, o teste é iniciado. As leituras dos experimentos duraram em média entre 30 e 40 minutos.

Para garantir a padronização dos resultados, elaboramos um protocolo de realização do experimento de leitura silenciosa e de leitura em voz alta. O participante foi comunicado que sua voz seria gravada enquanto fosse ler o texto em voz alta. Ele também teve a opção de desistir da pesquisa. Nada o obrigou a participar.

Foram escritas instruções na tela do computador e também dadas de forma oral pelo pesquisador. Os dois primeiros textos, um em português, e o outro em inglês, constituíram a primeira fase, uma seção de prática, antes das demais leituras, para que o pesquisado se sentisse confortável. Em seguida, todos os textos apareceram até a finalização da leitura. 
Durante o processo da coleta, foram realizadas perguntas de monitoramento aos participantes, como "Podemos continuar?", "Se você não quiser mais participar da pesquisa é só falar”. E assim, procedemos até o final da coleta de dados.

Tivemos que calibrar a posição dos olhos diante da máquina, conforme a posição de sentar. O participante teve que fixar o olhar na tela do computador para acompanhar o movimento de uma bolinha que aparece na tela, cujo deslocamento o participante deve acompanhar com o olhar sem mexer a cabeça. Em seguida uma tela aparecerá com círculos e o participante vai escolher a ordem que vai olhar fixamente; ao olhar esses círculos, eles se tornam de cor vermelha, sinal de que já estamos calibrando os seus olhos. Nesse momento, a tela do computador dá o feedback se a calibragem foi aceita ou, se fracassou. Para continuar, há mais uma calibragem. Depois, haverá mais uma sequência de círculos e o participante também deve seguir os movimentos dos pontos de calibragem da máquina mais uma vez.

Em sequência, ao pressionar a tecla de espaço no teclado, o participante vê apenas um círculo à sua esquerda, o texto aparece e o participante já deve ler os dois primeiros textos do experimento inicial. Ao finalizar, o participante aperta qualquer tecla alfabética do computador e o procedimento da coleta foi feito. Mais uma vez a frase aparece para a conclusão da coleta de dado.

1) Quando essa primeira etapa é concluída, o participante não pode mais se mexer. Caso contrário, temos que calibrar tudo mais uma vez.

2) O participante verá na tela todas as instruções sobre as leituras que devem ser realizadas. Após a leitura silenciosa, o participante precisa apertar QUALQUER TECLA ALFABÉTICA do computador. Se não apertar a tecla alfabética, o rastreador ocular continuará lendo o movimento dos olhos, e o resultado do experimento terá de ser descartado.

3) $\mathrm{O}$ assento e os pés do participante precisam estar bem apoiados, para garantir conforto durante a tarefa.

4) Se por acaso o participante ficar muito nervoso e não quiser dar continuidade à colaboração com a pesquisa do eye-tracking, pode desistir a qualquer momento.

5) Ao final, a pesquisadora transmite os agradecimentos e explica a importância dos resultados da pesquisa para o aprimoramento do ensino de inglês para envelhescentes e pessoas de terceira idade. 
Foram elaborados 20 textos-estímulo para o experimento: dez textos em português e dez textos em inglês (anexo 6). Desse número inicial, 2 foram selecionados para fazer a fase de treinamento, com o objetivo de verificar se o participante compreendeu as explicações em relação à postura e ao início da tarefa de leitura silenciosa. Os textos se apresentavam de forma aleatória.

Os participantes do experimento foram os alunos do curso de extensão: 10 envelhescentes, na faixa etária de 45 a 59 anos, 10 da terceira idade, na faixa etária de 60 a 84 anos de idade, 10 alunos do curso de Letras Inglês da Universidade Federal de Sergipe, na faixa etária de 23 a 35 anos, que leram em voz alta e silenciosamente, 20 textos em inglês e em português (cada um com cerca de 100 palavras). O experimento foi realizado no Laboratório Multiusuário de Informática e Documentação (Lamid) da Universidade Federal de Sergipe. Após a realização, os dados foram tratados quantitativamente. Foram analisados 22 testes. As exclusões foram devido a fatores relacionados ao grau nos óculos devido à falta de acuidade visual, cirurgia de miopia e de transplante de córnea e uso de maquiagem (rímel). 


\section{TEMPO DE LEITURA, TEMPO DE AULA E MOTIVAÇÃO}

Apresentamos, a seguir, os resultados dos estudos realizados, com o objetivo de verificar efeitos do tempo social e do tempo cognitivo na aula de língua inglesa para alunos envelhescentes e da terceira idade.

\subsection{TEMPO DE LEITURA}

No experimento de tempo de leitura, utilizamos os parâmetros de sacadas, fixações e regressões em três categorias: jovens, envelhescentes e pessoas da terceira idade. A realização de leituras de textos com cerca de aproximadamente 100 palavras, sendo dez textos em inglês e dez textos em português, permitiu que fosse medido o tempo entre as sacadas, fixações e regressões e que tivéssemos um padrão de tempo de leitura para as categorias jovens, envelhescentes e pessoas da terceira idade.

Quanto à regressão, imagina-se que, com a utilização de estratégias de leitura, os participantes façam um maior número de regressões na tentativa de compreender o texto. Conforme Frazier e Rayner (1982), Altmann, Gamham, Dennis (1992) e Rayner e Sereno (1994), 15\% de regressões em um total de sacadas são encontrados nas circunstâncias normais de leitura. Rayner (1998) comparou o processamento de leitura em diferentes condições e os textos identificados como de fácil leitura são aqueles que apresentam o menor número de regressões; em condições mais difíceis, o número de regressões aumenta.

Assim, em termos de duração, o tempo de leitura em condições de dificuldades é maior do que em condições mais fáceis. O tamanho do texto influencia na duração do tempo de sacadas, segundo Rayner (1998): quando a região de leitura for maior do que uma simples palavra, a duração das sacadas.

Apresentados os parâmetros, passemos à análise do tempo de leitura silenciosa e em voz alta.

\subsubsection{Leitura silenciosa e em voz alta}

Nos estudos de uma língua estrangeira, entendemos ser importante o reconhecimento inicial das palavras em leitura silenciosa e posteriormente em leitura em 
voz alta para que os aprendizes de uma língua estrangeira possam ter a oportunidade de ouvir o som e experienciar a sua verbalização. Dehaene (2012) descreve as duas vias de leitura simultâneas:

[...] dispomos todos de uma via direta de compreendê-los. Contudo, nos leitores experientes, a sonoridade das palavras continua a ser utilizada [...] a nível mais profundo do nosso cérebro, as informações sobre a pronúncia das palavras são automaticamente ativadas. As duas vias de tratamento das palavras, a via lexical e a via fonológica, funcionam, em paralelo, uma sustentando a outra. (DEHAENE, 2012, p.40)

Na leitura em voz alta, o leitor deve proceder a duas tarefas simultâneas. Ele deve proceder a uma linguagem oral equivalente à linguagem escrita e ele deve também reconstruir o significado do que ele está lendo, ou seja, procurando compreender a leitura. O leitor reconhece a codificação gráfica como uma linguagem fonológica oral. Esse processamento da leitura pode ser aprendido por alguém que não fale a língua, mas que pode ser memorizada e posteriormente verbalizada, como uma música. Mas o leitor, ao analisar a linguagem semântica, pode reconstruir o significado da linguagem escrita e assim compreender a decodificação.

Esses processos de decodificação de leitura devem ser automatizados ou bem assimilados e até mesmo autônomos. No ensino de uma língua estrangeira, o processamento de ensinar a decodificar é semelhante. Embora o conhecimento da primeira língua já esteja internalizado, o novo aprendiz executa o processamento de aprendizagem de uma língua estrangeira no modelo similar, com diferentes perspectivas de desenvoltura.

Embora os participantes façam movimentos de retorno de leitura e fixação mais demorados, possivelmente para compreender melhor o que leram, evidenciando o nível da acurácia, o objetivo do experimento, tanto da leitura silenciosa quanto em voz alta é identificar o tempo de duração da leitura, sem necessariamente aferir a compreensão. ${ }^{12}$

As hipóteses para o controle do tempo de leitura são:

- Todos os participantes são mais rápidos na leitura de textos em português do que de textos em inglês;

- Todos os participantes são mais rápidos na leitura silenciosa do que em voz alta;

12 Para mensurar a compreensão de leitura, um método utilizado é o teste cloze (cf. FREITAG et alii, 2015, 2010). 
- Participantes mais jovens demandam menos tempo do que os participantes envelhescentes, que, por sua vez, demandam menos tempo do que os participantes da terceira idade na execução dessas tarefas.

Gráfico 3: Desempenho dos grupos experimentais quanto ao tempo de leitura em voz alta e silenciosa, em textos em (A) português e em (B) inglês.

\section{$\boxminus$ Leitura Voz Alta $\boxminus$ Leitura Silenciosa}

(A)

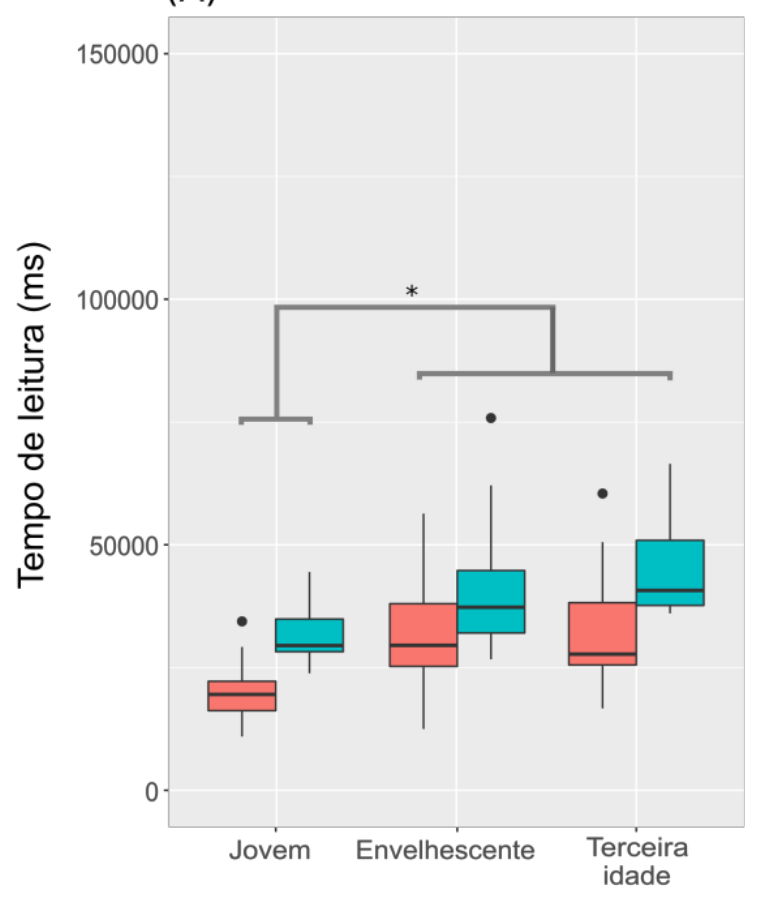

(B)

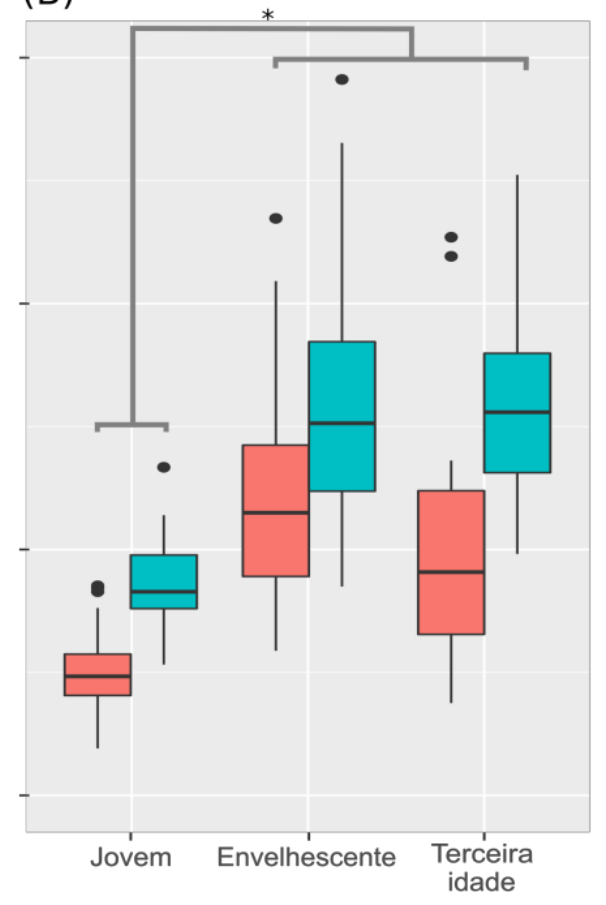

Grupos experimentais

O gráfico 3 apresenta os resultados do tempo médio de leitura dos textos em inglês e em português, em voz alta e silenciosa, quanto aos três grupos experimentais: jovens, envelhescentes e pessoas da terceira idade. O que podemos notar é que o tempo médio de leitura entre as categorias envelhescentes e terceira idade são semelhantes (tanto em português quanto em inglês) e maiores do que apresenta a categoria jovem, nas leituras silenciosas e em voz alta ([ANOVA para os textos em Português: $\mathrm{F}_{(2,176)}=38,71, \mathrm{P}<0,001$ $\mathrm{F}_{(1,176)}=66,63, \mathrm{P}<0,001$ ]; [ANOVA para os textos em Inglês: $\mathrm{F}_{(2,175)}=67,10, \mathrm{P}<0,001$; $\left.\left.\mathrm{F}_{(1,175)}=41,48, \mathrm{P}<0,001\right]\right) \mathrm{O}$ grupo de participantes jovens se diferenciou dos outros dois grupos significativamente para ambas as línguas, conforme resultado de um teste ANOVA de duas vias: grupo e tipo de leitura.

Nos textos em inglês, o tempo de leitura de todos os participantes foi maior do que nos textos em português. No entanto, alguns dos participantes tiveram um 
comportamento fora do padrão estabelecido, o que pode ser observado pela presença marcante da linha vertical, como pode ser verificado no gráfico 3).

O resultado permite afirmar que houve diferenças entre os grupos. As hipóteses sobre o tempo de leitura de envelhescente e pessoa da terceira idade ser maior do que a leitura de um jovem se confirmam diante dos dados apresentados: nos textos em português, a terceira idade necessita de mais tempo do que as demais categorias mostrando uma variação. No entanto, os envelhescentes parecem gastar mais tempo do que os membros do grupo da terceira idade, não obstante essa diferença não seja significativa. Vale ressaltar que os jovens obtiveram sua leitura no tempo padrão entre 200-250 ms.

A leitura silenciosa demonstra menor tempo do que a leitura em voz alta devido à preocupação do leitor em pronunciar os fonemas adequados de acordo com os traços fonológicos da língua. $\mathrm{O}$ tempo de leitura silenciosa é menor devido à não preocupação da pronúncia sobre as palavras. Já nos textos em inglês, o tempo foi muito maior. Os participantes da terceira idade apresentaram um tempo muito maior equivalente a aproximadamente $500 \mathrm{~ms}$ enquanto que, para a leitura em voz alta, aproximadamente 600-650 ms. Já para os envelhescentes, o tempo foi superior ao tempo gasto pela terceira idade, o que demonstra uma dispersão do tempo de leitura. Já os envelhescentes apresentaram maior dispersão no registro do tempo das tarefas executadas como os participantes da terceira idade, a exemplo do resultado da leitura silenciosa (está aproximadamente a 600-700 ms) para a leitura em voz alta eles também apresentam tempos muito maiores do que a terceira idade (com aproximadamente $200 \mathrm{~ms}$ ), embora não seja uma diferença significativa.

A diferença de tempo encontrada entre os grupos experimentais confirma a hipótese levantada. No entanto, convém destacar que o tempo de diferença de leitura entre os grupos de envelhescentes e de pessoas da terceira idade em relação aos mais jovens está na casa de milissegundos. Essa diferença pode ser crucial, por exemplo, para a concessão de carteira de habilitação (na medida em que, em milissegundos de diferença, podem causar um acidente de trânsito), mas em uma aula de 60 minutos, por exemplo, embora essa diferença exista, comprovando o que a literatura aponta quanto ao aumento da demanda de tempo na execução de tarefas, os milissegundos de diferença não interferem na aula de inglês. Esse resultado é importante para desmistificar o fato de que “idosos" são mais lentos e que por isso teriam dificuldades de aprender ou precisariam de 
mais tempo para executar atividades de leitura (eles precisam, mas o tempo demandado não influencia no conjunto geral de uma aula).

\subsubsection{Número de fixações}

A hipótese para o controle da variável fixações é de que participantes do grupo experimental mais jovem fazem menos fixações (com sacadas mais longas) do que os participantes envelhescentes, que, por sua vez, façam menos fixações do que os participantes da terceira idade, em função das limitações fisiológicas do envelhecimento (enrijecimento da musculatura). 
Gráfico 4: Desempenho dos grupos experimentais quanto ao número de fixações, em textos em (A) português e em (B) inglês.

\section{$\boxminus$ Leitura Voz Alta $\boxminus$ Leitura Silenciosa}

(A)

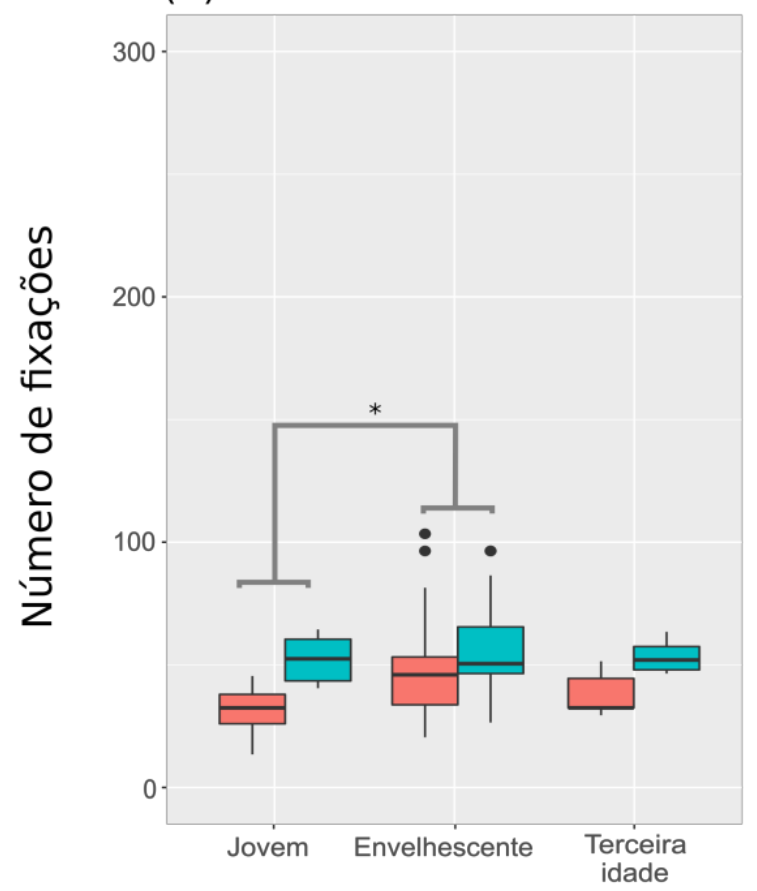

(B)

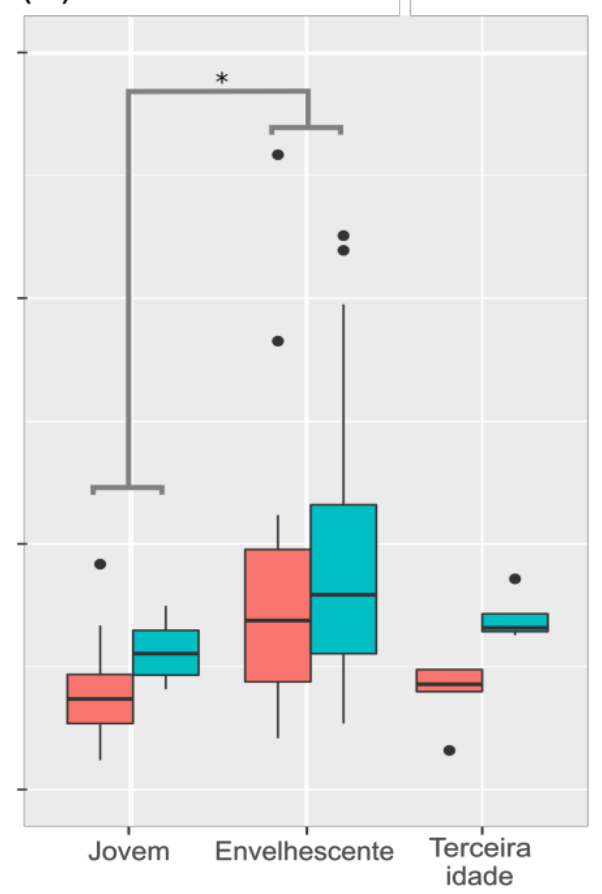

Grupos experimentais

No gráfico 4, identificamos que houve diferença entre os grupos de jovens e envelhescentes, corroborando parcialmente a hipótese levantada. O grupo da terceira idade obteve um número de fixações menor do que o dos envelhescentes, que obtiveram um número bastante acentuado de fixações. A realização de um teste ANOVA de duas vias, grupo e tipo de leitura, apontou que só os grupos de participantes jovens e envelhescentes tiveram diferenças significativas no número de fixações ([ANOVA para os textos em Português: $\mathrm{F}_{(2,122)}=10,70, \mathrm{P}<0,001 ; \mathrm{F}_{(1,122)}=24,12, \mathrm{P}<0,001$ ]; [ANOVA para os textos em Inglês: $\left.\left.\mathrm{F}_{(2,121)}=9,827, \mathrm{P}<0,001 ; \mathrm{F}_{(1,121)}=1,345, \mathrm{P}>0,05\right]\right)$.

Nas análises dos dados apresentados, podemos estabelecer um padrão de 68,5 palavras nos textos em português, com uma mediana de 68,0 e um desvio padrão de 10,0. Já nos textos em inglês, a média de palavras foi de 82,9, a mediana de 79,5 e o desvio padrão de 16,5 .

Podemos observar no gráfico 4 que, quanto aos participantes em relação aos grupos experimentais jovens, envelhescentes e pessoas da terceira idade, as fixações foram mais executadas pelos envelhescentes do que pelos participantes da terceira idade. 
Já os jovens obtiveram menor número de fixações. Esse resultado só permite afirmar que houve diferenças entre os grupos; um grupo mostrou um número de fixação menor que o outro. Lembramos que não estamos analisando compreensão de leitura e sim o tempo da leitura. A linha vertical mostra que houve uma diferença muito maior entre os membros das mesmas categorias.

Rayner (1998) aponta que até mesmo os leitores hábeis fazem regressões diante de algumas dificuldades da língua, como em estruturas de frases mais elaboradas. Leitores em geral fazem mais fixações, menos sacadas e mais regressões. Os leitores costumam pular, traçar, omitir palavras durante a leitura de textos, mas, mesmo assim, no contexto, isso não é prejudicial. A duração da fixação na palavra pode trazer significações de interpretação sobre palavra, contexto, tempo, sintaxe. Adicionamos também o fator escolaridade e habitualidade de leitura, que são informações relevantes que poderiam ser observadas.

Embora os estudos de Vonk, Cozjin (2003), Rayner, Chace e Slattery (2006) sugiram que os leitores façam a compreensão do texto durante a leitura, eles também alertam para as várias intercorrências sobre o movimento ocular, que refletem, no tempo de fixação, o processo dos leitores em obter significado. Outra observação pode estar relacionada ao estado emocional de cada pessoa, assim como também toda a preparação antecedente aos experimentos, tais como óculos, maquiagem, transplante das córneas ou catarata.

O fato de envelhescentes e pessoas de terceira idade realizarem mais fixações para a leitura aponta para a necessidade de se considerar esse fator na hora de desenvolver materiais didáticos de suporte à leitura, com uma diagramação que permita movimentos confortáveis de sacadas (mancha da página mais estreita, por exemplo).

\subsubsection{Duração das fixações}

Quando as questões de experimentos focalizam na sentença ou no processamento de uma palavra, o primeiro passo do tempo da leitura definirá um número de fixações que deverão ser medidos para se obter um tempo de leitura.

Quando lemos, olhamos as cenas, ou a procura por um objeto, continuamente fazemos esse movimento ocular chamado de sacadas, entre as sacadas, nossos olhos permanecem relativamente ainda durante as fixações por $200-300 \mathrm{~ms}$ por segundos. Em leitura silenciosa, a duração de fixação é (225 ms -2 sacadas-8 letras); leitura oral (275ms. -1.5 sacada -6 letras); percepção visual (275 ms, 3 sacadas); percepção 
de uma cena (330 ms, 4 sacadas); leitura de uma música (375 ms, 1 sacada); digitação (400 ms 1 sacada, 4 letras). (RAYNER, 1998, p. 373, tradução nossa) $)^{13}$

As fixações mostram que os leitores estão à procura de compreensão sobre a palavra ou frase. O movimento sacádico dura em torno de 30 a $50 \mathrm{~ms}$, com uma amplitude média de 7 a 9 espaços de letras; a fixação dura em média 200 a 250 ms (leitor não hábil).

Do mesmo modo que, para o número de fixações, a hipótese para o controle dessa variável é de que participantes do grupo experimental mais jovem fazem fixações com maior duração do que os participantes envelhescentes, que, por sua vez, fazem fixações com maior frequência do que os participantes da terceira idade.

Gráfico 5: Desempenho dos grupos experimentais quanto à duração média das fixações, em textos em (A) português e em (B) inglês.

\section{Leitura Voz Alta $\boxminus$ Leitura Silenciosa}

$(A)$

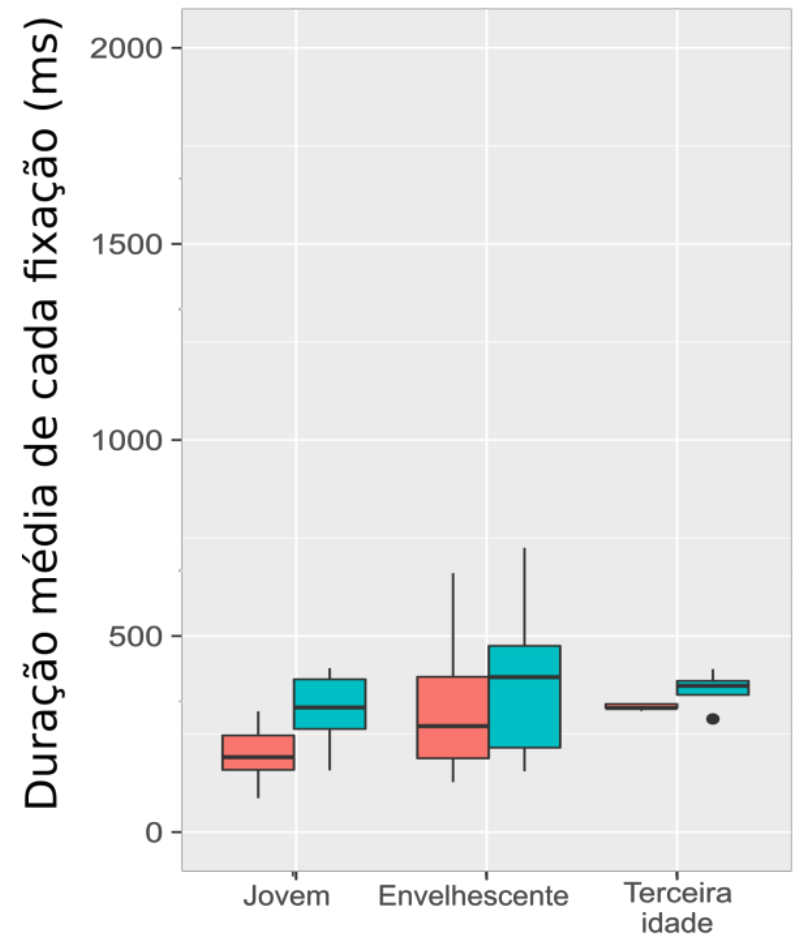

(B)

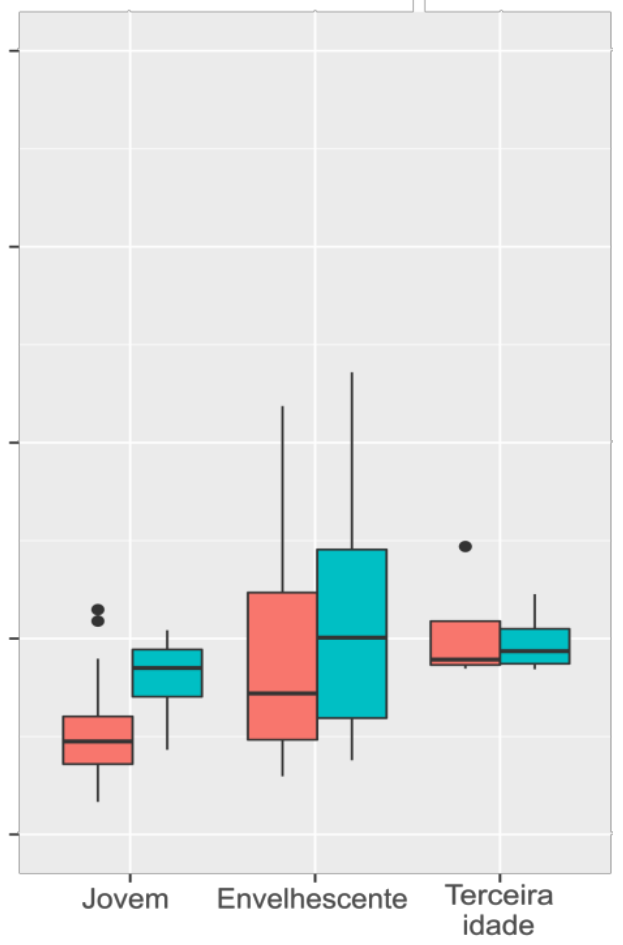

Grupos experimentais

\footnotetext{
${ }^{13}$ When we read, look at a scene, or search for an object, we continually make eye movements called saccades. Between the saccades, our eyes remain relatively still during fixations for about 200-300 ms...Saccades are rapid movements of the eyes with velocities as high as $500^{\circ}$ per second. For Silent reading (225 ms. 2- saccades- 8 letters); Oral reading 275 ms. (1.5 saccades 6 letters); Visual search 275 ms. (3 saccades); Scene perception $330 \mathrm{~ms}$. (4saccades); Music reading $375 \mathrm{~ms}$.(1 saccade ); Typing $400 \mathrm{~ms}$. (1 saccade). 373 p. $2^{\circ} \S$
} 
No gráfico 5, apresentamos o quadro comparativo de duração média da fixação em ms de dezenove participantes. Ao observar na leitura em inglês, entre as categorias jovens, envelhescentes e da terceira idade, os envelhescentes apresentaram uma duração média maior que as outras duas categorias; contudo, as diferenças não são significativas, o que não corrobora a hipótese da perda de acurácia, devido à idade ([ANOVA para os textos em Português: $\mathrm{F}_{(2,122)}=0,17, \mathrm{P}=0,844 ; \mathrm{F}_{(1,122)}=0,403, \mathrm{P}=0,527$ ]; [ANOVA para os textos em Inglês: $\left.\left.\mathrm{F}_{(2,121)}=0,960, \mathrm{P}=0,386 ; \mathrm{F}_{(1,121)}=1,117, \mathrm{P}=0,293\right]\right)$.

\subsubsection{Movimentos oculares}

Segundo Dehaene (2012), um bom leitor deve filtrar e ou rejeitar as variações que não sejam pertinentes à leitura. Ressalta ainda sobre o saber preservar e ampliar os detalhes das funções da língua (muitas vezes palavras minúsculas se diferenciam de palavras próximas, com distinção apenas de morfemas semelhantes). A duração da fixação demorada é definida como a somatória das fixações na palavra até vir a seguinte em uma nova direção. A medida foi inicialmente utilizada por Just e Carpenter (1980), para indicar que o tempo de leitura era associado ao processamento de uma palavra.

Encontros consonantais, palavras desconhecidas, números ordinais e ou cardinais afetam o olhar do leitor para fazer a captura da decodificação da palavra em relação a entoação, ritmo, tempo de leitura (RAYNER, 1998). Nesse sentido, esses aspectos linguísticos dos sons da língua atuam durante a leitura e influenciam a predibilidade da leitura do texto tendo muitas vezes que fazer o go-past (retorno-de-leitura) e consequentemente afetando o tempo na leitura.

Estudos indicam que as variáveis como frequência (INHOFF; RAYNER, 1986; RAYNER; DUFFY, 1988), previsão (EHRLICH; RAYNER, 1981; RAYNER; WELL, 1996) e a idade de aquisição de uma palavra (JUHASZ; RAYNER, 2003, 2006) influenciam fortemente sobre o tempo de fixação na palavra. O movimento ocular reflete as dificuldades que os leitores menos hábeis têm em decodificar as palavras e entender o texto. Palavras simples (monomorfêmicas), como artigo, preposição, conjunção não trazem significado ao texto, enquanto palavras compostas (morfêmicas), como verbo, adjetivo, trazem significações ao texto. Se os leitores sempre fazem uma sacada e uma fixação em cada palavra, então a média de duração da fixação refletiria no processamento do tempo da palavra. 
Na realidade, alguns leitores pulam palavras (cerca de dois terços das palavras são tipicamente fixadas, palavras curtas e palavras previsíveis sempre são puladas) e algumas vezes os leitores fazem mais do que uma fixação em uma palavra antes de mover para outra palavra. Assim sendo, quando as questões de experimentos focalizam em um processamento de palavras simples, os pesquisadores de movimento ocular reportam tipicamente um número de relações de medidas para capturar o tempo do processamento da palavra, assim como a duração das primeiras fixações (a duração da primeira fixação na palavra), a duração de fixação simples (casos quando apenas uma fixação é feita na palavra), a duração de olhar fixante gaze-duration (a soma de todas as fixações sobre a palavra anterior em movimento para uma outra palavra) e o tempo total de fixação (soma de todas as fixações, incluindo regressão na palavra). Complementarmente, a probabilidade de fixação na palavra e a frequência de regressões fora da palavra são também reportadas (VONK; COZIKN, 2003).

A hipótese para o controle dos movimentos oculares considera que as dificuldades dos discursos global ou local aumentam as durações de fixações assim como o número das fixações e a probabilidade de regressões durante a leitura silenciosa de longas passagens do texto. Esse argumento tem sido evidenciado em experimentos de reconhecimento de palavras e processamento de sentenças, contudo a extensão de qual é a dificuldade que geralmente afeta o movimento ocular é menos clara (RAYNER, 1998).

Nesse sentido, foram feitas leituras com marcação do tempo para verificar quanto tempo os envelhescentes levam para fazer o processamento da leitura com uso da ferramenta em eye-tracking e qual a diferença de tempo será estabelecida para obtermos o tempo de leitura para os participantes da terceira idade. Hipoteticamente sabemos que os participantes da terceira idade são mais lentos devido às suas perdas cognitivas decorrentes da idade que fazem com que, com o decorrer do tempo, naturalmente, eles diminuam as suas agilidades e, fisiologicamente, os músculos e plasticidade já se mostrem diferentes. Por isso, foram feitas análises em relação às regressões, fixações e sacadas que traduzem outras interpretações, chamadas de características básicas do movimento ocular.

Quando as questões de experimentos focalizam na sentença ou no processamento de uma palavra, o tempo da leitura (a somatória de todas as fixações na região) é computado. Uma medida adicional é a do tempo de regressão (go-past), a soma de todos as fixações da primeira leitura a entrar em uma região até a saída na direção linear (forward). Essa medida também é chamada de duração de trajetória de regressão e inclui 
qualquer regressão fora da região anterior para o deslocamento da leitura seguinte (forward) no texto; quais medidas são mais úteis ao analisar o dado, que pode variar de um estudo geral para um mais específico. Entendemos que os autores demonstraram as possibilidades de interpretação de leitura do texto no movimento ocular em relação a sacadas, fixações, regressões. Vonk e Cozijn (2003) e Rayner, Chace e SLATTERY (2006) apontam fatores que desencadeiam dificuldades de leitura, tanto para o leitor hábil como menos hábil, como palavras que contenham informações numéricas, encontros consonantais, palavras homófonas, etc.

Assim, com o ato da repetição das regressões dos leitores, para uma região anterior do texto, o leitor busca compreender o que ele não entendeu anteriormente fazendo regressões, assim como também deve ser observado o número de vezes de fixações para regiões anteriores do texto ou início do texto.

A duração da primeira fixação na palavra (região) reflete o processamento de dificuldade do leitor. Elas mostram os efeitos de frequência de palavra. Essa medida é menos usada se a região da visão for menor. Um campo maior requer mais fixações para serem processadas. Então a primeira indicação de fixação não será o indicado para completar o processamento da região do campo de visão.

A seguir, apresentamos dois textos/testes-pilotos em inglês. O participante teve que ler em voz silenciosa e ou em voz alta (dependendo da ordem apresentada no experimento).

Figura 11: Texto 1 - piloto leitura silenciosa em inglês

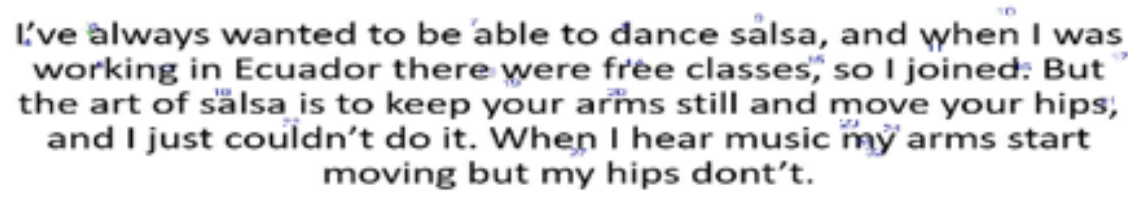

l've always wanted to be able to dance sâlsa, and when I was working in Ecuador there were free classes," so I joined: But and I just couldn't do it. When I hear music my arms start moving but my hips dont't. 
Figura 12: Texto 3 - piloto leitura silenciosa em inglês

Would you like to live in a beautiful house in the heart of the Canadian Rocky Mountalins? It's spacious house with four bedrooms, a living room, a large kitchen, two bathrooms, and a store room.'It has a large balcony, which is ideal for eating outside in the summer. The house has wooden floors, - a jacuzzi, cable televisjon, and internet. It's quiet, safe neighbourhood and the neighbours-are very warm and friendty. This house is perfect for families or two couples. It's a no smoking house and, sorry, no pets.

Apresentamos também dois textos/testes-pilotos em português. O participante teve que ler em voz silenciosa e ou em voz alta (dependendo da ordem apresentada no experimento).

Figura 13: Texto 1 - piloto leitura silenciosa em português

A língua é um fato social e veicula, além de informações referenciais, também significados sociais, estilisticos e culturais, expressos em modos de ação dos interlocutores refletidos em diferenteș funções da linguagem. Quando falamos, exteriorizamos nossos pensamentos, sentimentos, atitudes e também rievelamos a nossa identidade social e regional, envolvendo fatores refletidos nas relaçõões sociais entre os participantes de umassituação comunicativa.

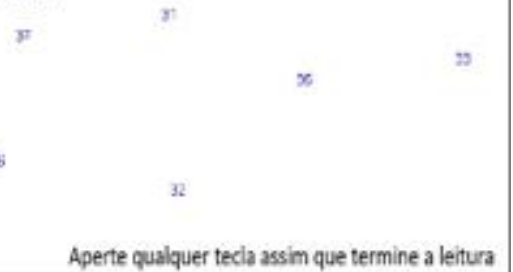

Para fins de testagem, o texto deve ser centralizado para facilitar a área de leitura que o participante deve ler. O objetivo da leitura foi calcular o tempo de leitura. Palavras comuns, como preposição, conectivo e artigos são as palavras que não trazem significados de palavras e muitas vezes os olhos pulam a leitura, enquanto que palavras complexas são aquelas que mais tendem a receber as fixações. Os participantes, em geral, não apresentaram problemas de leitura nos textos em português. 
Figura 14: Texto 2 - piloto leitura silenciosa em português

É da natureza humana viver em grupos, "que são formados pelos mais diversos critériosı idade, hábitos è atitudes, profissão, e assim por diante. Podemos marcar nossa identidade pela afinjidade a certos grupos sociais ou a grupos regionais. Os membros desses grupos compartilham características e afinidades, traços de identidade, e, dentre eles, marcas linguisticas.

Os movimentos sacádicos, no entanto, não foram contabilizados nesse estudo. As regressões foram identificadas para se quantificar e tirar a média que serão somadas e divididas pela média aritmética. Essa média será a quantificação de cada texto, isto é, o mesmo texto para todos os participantes dos experimentos. Vale ressaltar que foram aplicados os testes em 19 participantes dentre as três categorias (jovem, envelhescentes e da terceira idade), mas os resultados apresentados não se referem a todos os 19 participantes, dois experimentos foram descartados na análise final devido às inconsistências no desempenho dos testes. Assim, foram considerados 17 testes.

O descarte dos testes se deve a inconsistências de ocorrências, como uso de grau em óculos, cirurgia de catarata e também alguma maquiagem nos cílios. Ainda que previamente avisados, alguns participantes ignoraram as solicitações.

A partir do que é evidenciado na literatura, as palavras de fixação e ou regressão deverão ser as palavras que tenham duplicidade de letras, encontros consonantais, encontros vocálicos e palavras verbais, baseadas em Rayner (1998), Vonk e Cozijn (2003), e palavras de difícil pronúncia. As regressões que acontecem na mesma linha e outras possíveis ocorrências que aparecem nos registros como outras linhas não podem ser consideradas. Só foram considerados os textos que apresentaram maior número de regressões que outros.

Os resultados do gráfico 6 se referem aos 17 dos 30 participantes cujo movimento ocular conseguimos registrar. Foram descartados os registros que apresentaram falta de linearidade de leitura e falta de fixações e regressões para selecionar dois experimentos das três categorias. 
Gráfico 6: Número de regressões em função dos grupos experimentais: (A) português e em (B) inglês

\section{曰}

(A)

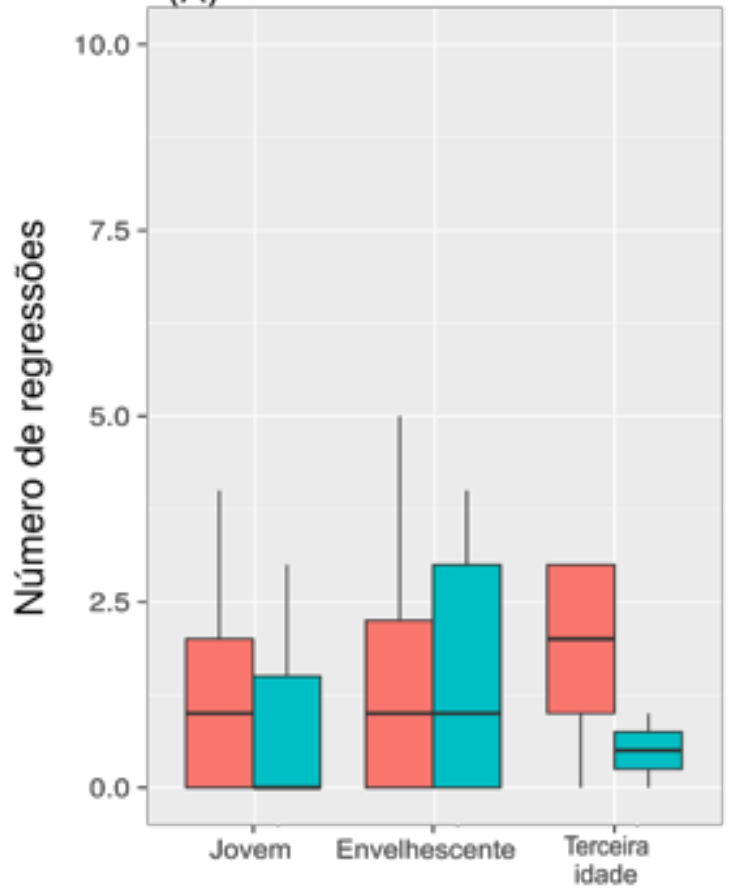

(B)

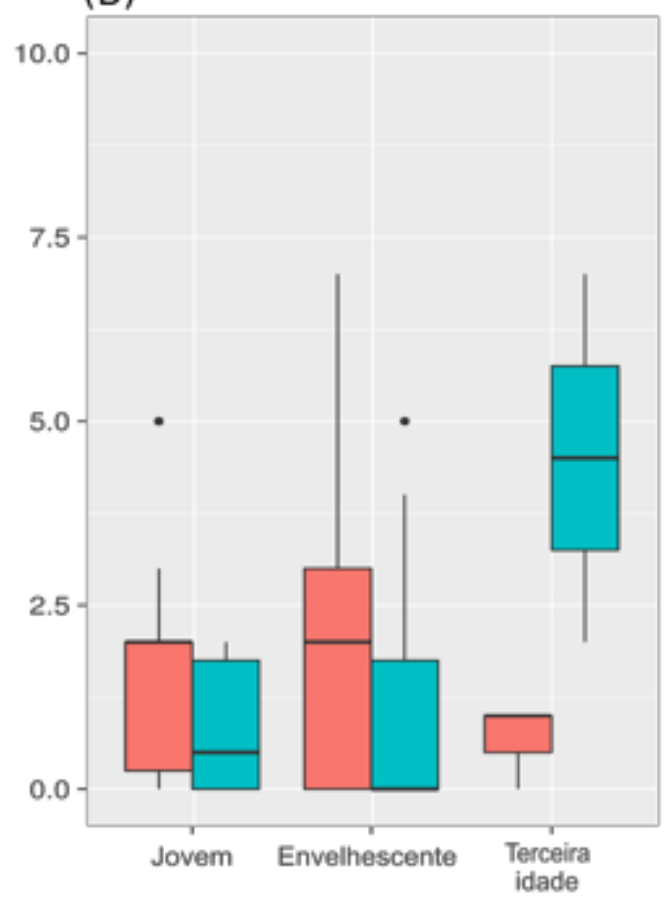

\section{Grupos experimentais}

Nas análises feitas sobre o número de regressões, não houve diferença significativa em nenhum dos grupos estudados. Houve muitas dispersões de leitura entre as linhas verticais. A ausência de um estudo de compreensão impede que se façam explanações além da constatação acima, o que aponta para um campo de pesquisas futuras ([ANOVA para os textos em Português: $\left.\mathrm{F}_{(2,92)}=0,774, \mathrm{P}=0,464 ; \mathrm{F}_{(1,92)}=0,750, \mathrm{P}=0,389\right]$; [ANOVA para os textos em Inglês: $\left.\left.\mathrm{F}_{(2,81)}=0,294, \mathrm{P}=0,7458 ; \mathrm{F}_{(2,81)}=4,307, \mathrm{P}=0,0411\right]\right)$.

\subsection{TEMPO PLANEJADO E TEMPO EXECUTADO DAS AULAS}

Ainda considerando a dimensão cognitiva, mas também a dimensão social do tempo, realizamos um estudo sobre a organização do curso, em relação ao tempo planejado e ao tempo executado de cada aula, considerando as evidências apontadas na literatura em relação à execução de tarefas e o dispêndio de tempo por parte dos idosos (o que foi confirmado, de certo modo, no estudo de leitura). Nossa hipótese é de que as aulas demandam mais tempo do que o planejado. Para identificar em que momentos há maior demanda de tempo, as aulas foram segmentadas em atividades e o tempo, aferido para cada uma das atividades. 
Os relatórios do ministrante e as fichas de acompanhamento de cada uma das aulas foram analisadas e tabuladas, a fim de conferir cada registro que foi feito durante a coleta de dados, tanto do tempo como dos passos das aulas. A rotina de classe das aulas do projeto era composta por dez atividades as quais denominamos no quadro 4 .

Quadro 4: Atividades que compõem a aula

A1 - Aplicação teste emocional

A2 - Verificar ativ. Aula anterior

A3 - Reprodução do vídeo da lição

A4 - Explicação de vocabulário e funções indutiva no texto

A5 - Leitura em voz alta e ou silenciosa dos textos

A6 - Revisar estruturas da língua etc

A7 - Atividade extra e ou lúdica (música)

A8 - American x Brazilian Culture

A9 - Aplicar teste emocional

A10 - Coffee Break

O tempo de cada atividade foi medido e está sistematizado nos gráficos 7 e 8 , respectivamente, turma 1 e turma 2. 
Gráfico 7:Tempo de duração de cada atividade - Turma 1

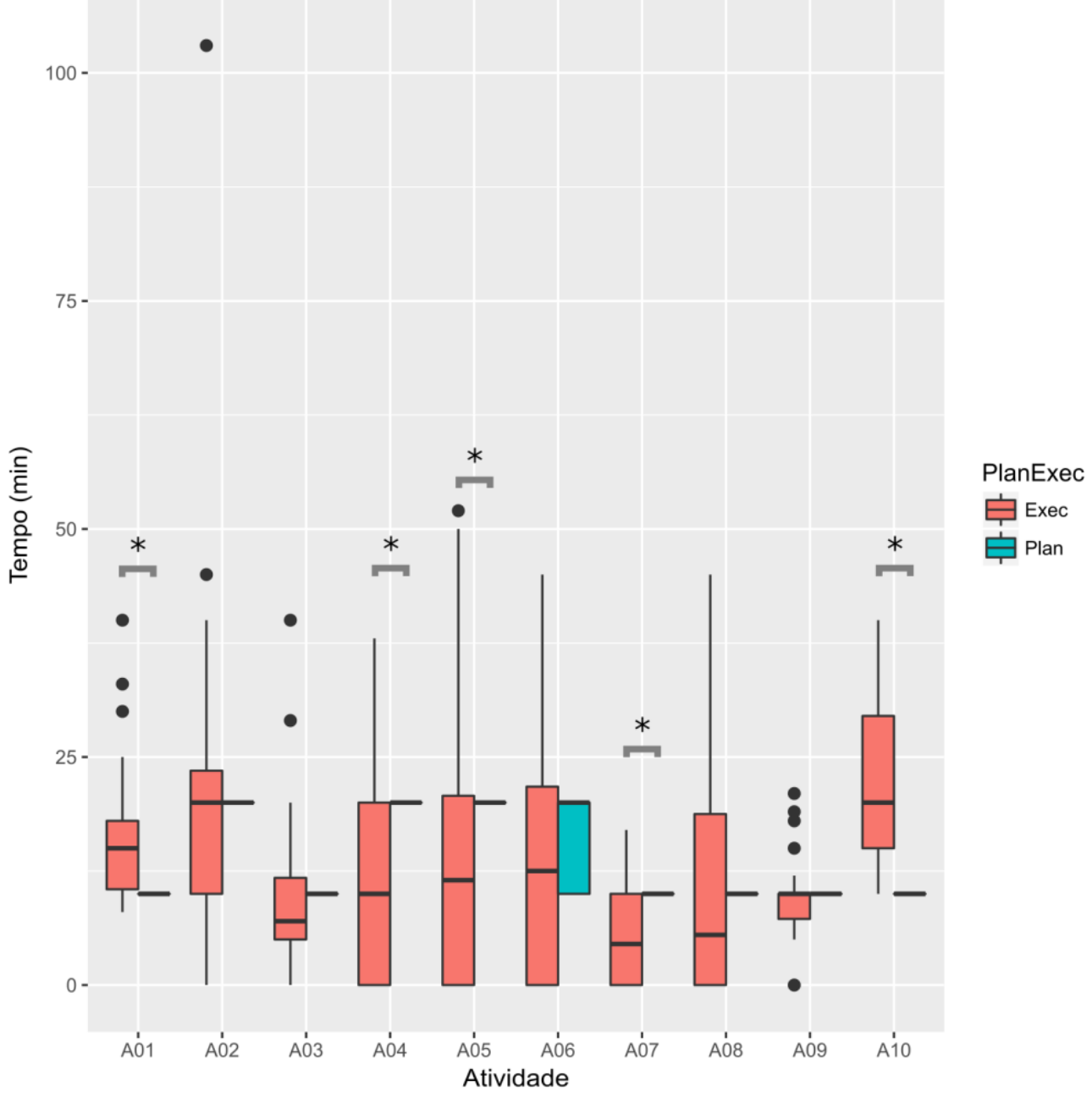


Gráfico 8: Tempo de duração de cada atividade - Turma 2

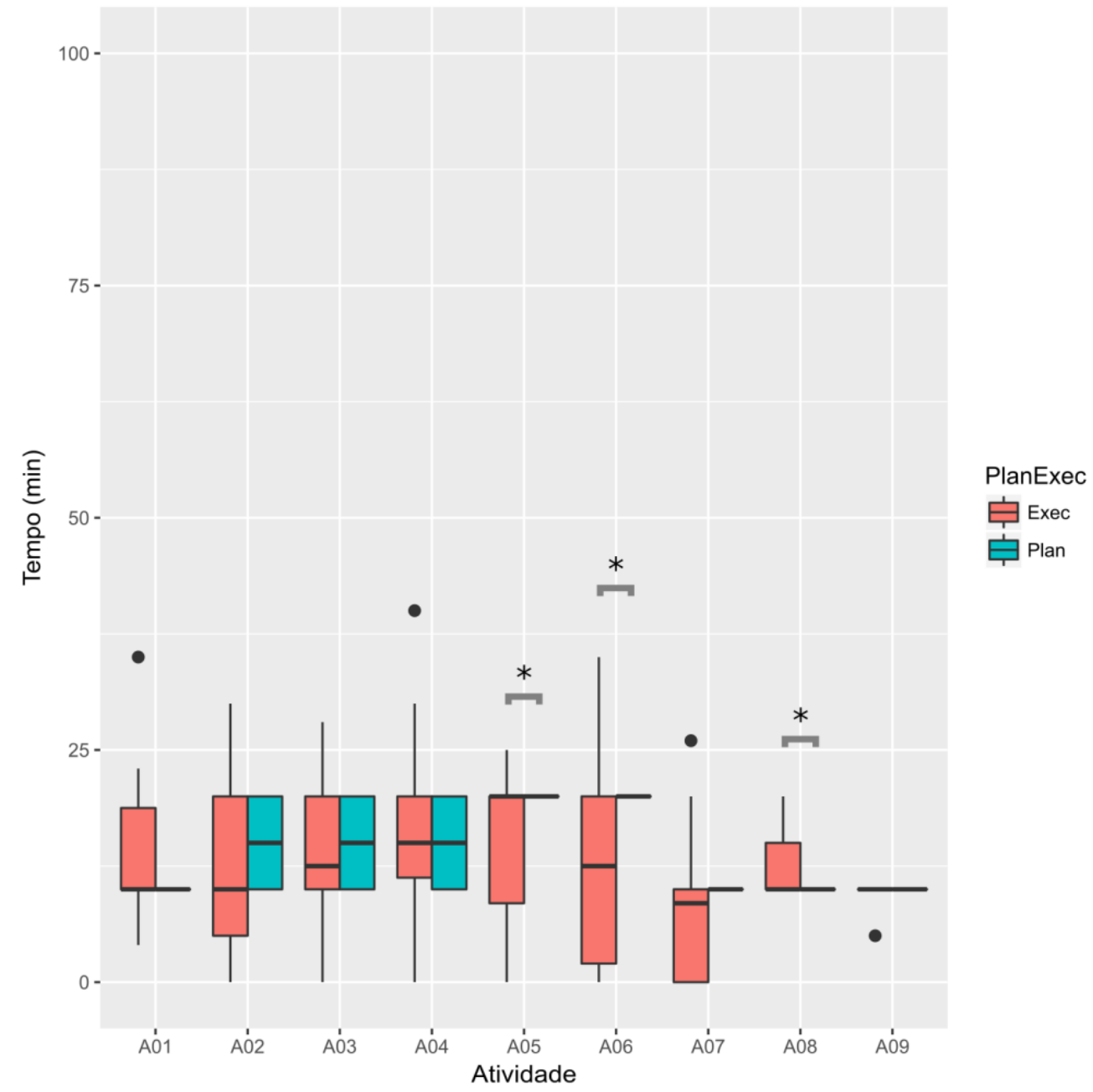

Nos gráficos 7 e 8, relativos ao tempo planejado e executado do grupo das aulas, a linha grossa representa a não variação no tempo planejado e executado, a exemplo das atividades A2, A3 e A4. A identificação entre o quadro verde significa que houve uma mudança no tempo da atividade A6.

Na turma 1, ao analisarmos o levantamento do tempo das atividades das aulas planejadas e executadas, podemos observar que basicamente não houve diferença no tempo das aulas planejadas, mantendo-se o planejamento para se ministrar as atividades de rotina de classe. Em trinta encontros de aulas ministradas, de março a junho de 2016, a média de cada aula planejada resultou em 136,6 min. Embora as aulas executadas apresentem uma média de 135,2 min para a turma 1, nos desmembramentos dos dias das aulas, as atividades de aplicação de teste emocional (A1), verificação das atividades das aulas anteriores (A2), explicação de vocabulário indutiva no texto (A4), atividades extras (A7) e coffee break (A10) sempre ultrapassaram o tempo planejado, o que sugere a necessidade de um de preparo diferenciado dos alunos-professores para saber lidar com 
o público específico. Do ponto de vista estatístico, a realização de um teste-t entre os tempos de aula planejado e executado para a turma 1 aponta para diferenças significativas entre o tempo planejado e o executado nas atividades A1, A4, A5, A7 e A10 (A1: $\mathrm{t}_{(29)}=$ 4,89, $\mathrm{P}<0,005^{12}, \mathrm{~A} 2: \mathrm{t}_{(29)}=0,1419 ; \mathrm{P}=0,888, \mathrm{~A} 3: \mathrm{t}_{(29)}=0,04516 ; \mathrm{P}=0,9643 ; \mathrm{A} 4: \mathrm{t}_{(29)}=$ $-3,1924, \mathrm{P}=0.003^{12} ; \mathrm{A} 5: \mathrm{t}_{(29)}=-2,4667, \mathrm{P}=0,01988 ; \mathrm{A} 6: \mathrm{t}_{(29)}=-1,0357, \mathrm{P}=0,3089 ; \mathrm{A} 7$ : $\mathrm{t}_{(29)}=-4,3537, \mathrm{P}=0,000152 ; \mathrm{A} 8: \mathrm{t}_{(29)}=0,8101, \mathrm{P}=0,42245 ; \mathrm{A} 9: \mathrm{t}_{(29)}=-0,62127, \mathrm{P}=$ 0,5393; A10: $\left.\mathrm{t}_{(29)}=7,9629, \mathrm{P}<0,005\right)^{14}$.

Já para a turma 2, com apenas 15 encontros de aula, também planejados, resultou em uma média de 116,6 min de aula. A realização de um teste-t entre os tempos de aula planejado e executado para a turma 2 apontou para diferenças significativas entre o tempo planejado e o executado nas atividades A5, A6 e A8 (A1: $\mathrm{t}_{(29)}=1,6425, \mathrm{P}=0,1244, \mathrm{~A} 2$ : $\mathrm{t}_{(29)}=-1,1991 ; \mathrm{P}=0,2519, \mathrm{~A} 3: \mathrm{t}_{(29)}=-0,66892 ; \mathrm{P}=0,5153 ; \mathrm{A} 4: \mathrm{t}_{(29)}=0,62804, \mathrm{P}=0.5409$; A5: $\mathrm{t}_{(29)}=-2,2948, \mathrm{P}=0,03904 ; \mathrm{A} 6: \mathrm{t}_{(29)}=-2,2762, \mathrm{P}=0,0404 ; \mathrm{A} 7: \mathrm{t}_{(29)}=-1,0481, \mathrm{P}=$ 0,3137; $\left.A 8: \mathrm{t}_{(29)}=2,5135, \mathrm{P}=0,02592 ; \mathrm{A} 9: \mathrm{t}_{(29)}=-1, \mathrm{P}=0,3356\right)$.

Lembramos, no entanto, que, na turma 2, embora os alunos sejam considerados da terceira idade (4 alunos apenas), eles dispensaram o coffee break (que é o momento de interação social), por serem bastante ativos ainda no seu tempo social de vida, atuando no mercado de trabalho, embora oficialmente aposentados. Outra observação para essa turma é que os alunos sempre chegam posterior ao horário de início da aula devido ao trânsito. No entanto, são assíduos e demonstram participação ativa na aula pelo tempo maior nas verificações das atividades das aulas anteriores (A2) e também na explicação de vocabulário e funções indutivas no texto (A4) e nas discussões de cultura brasileira e americana do item A8, evidenciando, assim, sua participação ativa, mas com necessidade de um tempo maior para responder as atividades executadas.

Considerando nossa hipótese de que o tempo executado seria maior do que o planejado, os dados empíricos evidenciam que não houve a sua corroboração: o tempo global de execução, em ambas as turmas, foi inferior ao tempo planejado. Isso sugere que o planejamento das aulas sofre efeitos de estereótipos relacionados ao envelhecimento, de que idosos são mais lentos, por exemplo (VIEIRA; LIMA, 2015). Analisando as atividades, constatamos que as que demandaram mais tempo do que o planejado foram, além das aulas de revisão, as que têm cunho social, como as fichas emocionais e o coffee-

\footnotetext{
${ }^{14}$ Valor de alpha utilizado 0,005, usando o ajuste de Bonferroni.
} 
break. Esses resultados sugerem que as atividades de socialização precisam ser consideradas com maior tempo, mas as atividades de cunho pedagógico, não. De certa forma, os resultados se alinham ao que foi constatado no estudo de leitura: embora demandem mais tempo para a execução de tarefas, como foi evidenciado, a diferença não interfere em uma aula, e isso faz com que o planejamento seja superdimensionado, muitas vezes por estereótipo e preconceito, como apontam Vieira e Lima (2015).

\subsection{MOTIVAÇÃO PARA A AULA}

Considerando que o lócus da pesquisa é um curso livre para participantes que não são obrigados a frequentá-lo (diferentemente de um público da faixa etária de escolarização obrigatória, por exemplo), nossa hipótese para aferirmos o estado emocional é de que ele é predominante positivo. Ao aferir as emoções na entrada e na saída, como apresentamos na metodologia, em cada aula documentada, visamos a identificar se o curso instiga mudanças emocionais em seus participantes.

Durante o período de coleta de dados, alternadamente, aplicamos 5 modelos diferentes de testes emocionais, o que denominamos de "fichas emocionais" (anexo 3), cujo objetivo foi permitir avaliar o estado de espírito de cada aluno. A estratégia visava a deixar os participantes das aulas do curso de extensão descontraídos, sem que eles percebessem que estavam sendo analisados pela motivação e por seu estado emocional através das figuras nos variados modelos dos testes apresentados. As palavras possuíam funções adjetivas que revelavam estado de motivação em cada desenho para ser marcado por cada participante. Do ponto de vista pedagógico, as fichas emocionais auxiliaram em atividades de ampliação do vocabulário, já que houve a oportunidade de trabalhar com os alunos os significados das palavras adjetivas em inglês e também de justificar por escrito suas opções de respostas abertas, o porquê da resposta.

Para fins de análise dos dados, fizemos o desmembramento dos participantes: Turma 1, com 30 aulas documentadas, ministradas nas segundas e quartas-feiras, contando com 15 alunos, 8 envelhescentes e 7 participantes da terceira idade.

A turma 2, com 15 aulas documentadas, ministradas nas sextas-feiras, com apenas quatro alunos, que denominamos de terceira idade.

Dos dezenove alunos participantes do curso de extensão, das turmas 1 e 2 , dois eram do gênero masculino da terceira idade (aposentados - um motorista de caminhão, o outro comerciante); os outros 7 participantes da terceira idade eram do gênero feminino, 
eram aposentadas (comerciantes, professoras universitárias, fisioterapeuta, bancária, costureira, dona de casa). Dos 8 envelhescentes, todos do gênero feminino, eram ativas no mercado de trabalho (professora do ensino médio, funcionária pública e donas de casa).

Os participantes recebiam na entrada das aulas as fichas emocionais e permaneciam com elas até a saída, quando entregavam as fichas ao ministrante e ou documentador antes de saírem das aulas. Os alunos foram instruídos que poderiam marcar com X ou pintar com lápis de cor oferecido a todos na aula.

Após a tabulação das fichas, os dados foram submetidos ao tratamento estatístico, visando a identificar a motivação, no início da aula, e satisfação dos alunos após a aula.

Gráfico 9: Testes emocionais dos participantes da terceira idade - Turma 1 (seg/qua)

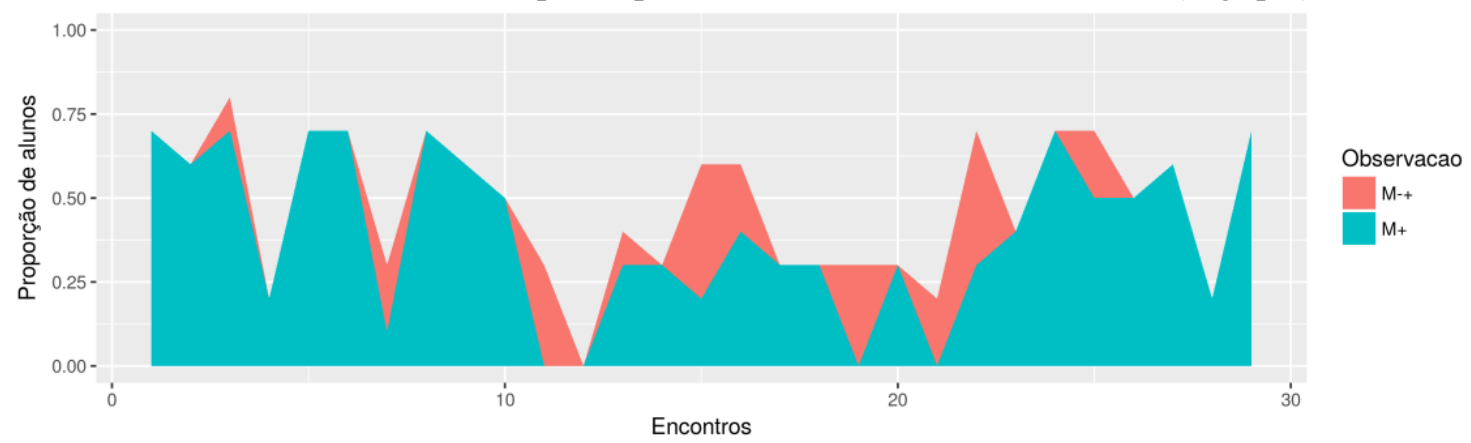

A área vermelha representa a proporção de mudanças emocionais tanto positivas quanto negativas ( $\mathrm{M}+-$-). A área azul representa a proporção de mudanças positivas $(\mathrm{M}+)$.

Como podemos ver no gráfico 9, os participantes da terceira idade apresentam um grau de satisfação superior ao de insatisfação. No entanto, a presença de insatisfação está relacionada a problemas de ordem pessoal como dores, problemas familiares, falta de estacionamento para colocar o carro ou no dia de aula que tinha diversas explicações sobre funções gramaticais.

Gráfico 10: Testes emocionais dos participantes envellhescentes - Turma 1 (seg/qua)

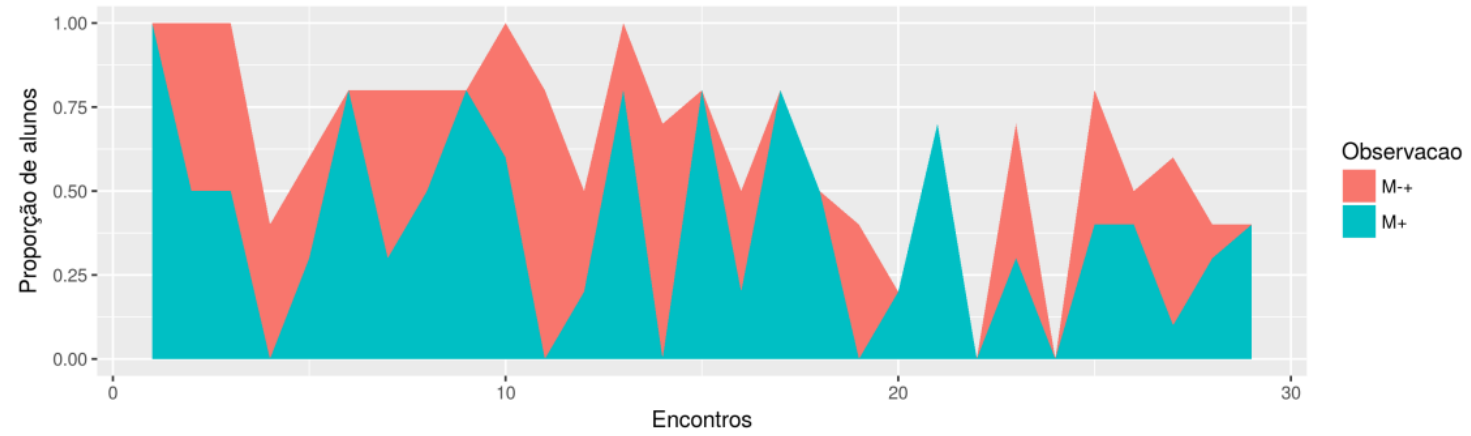

A área vermelha representa a proporção de mudanças emocionais tanto positivas quanto negativas (M+-). A área azul representa a proporção de mudanças positivas $(\mathrm{M}+)$ 
O gráfico 10 ressalta a continuidade de grau de satisfação dos envelhescentes em relação às mudanças negativas. Eles também tiveram os mesmos problemas que o grupo da terceira idade: problemas de ordem pessoal como dores, problemas familiares, falta de estacionamento para colocar o carro ou no dia de aula que tinha diversas explicações sobre funções gramaticais.

Observa-se, no entanto, que o grau satisfação aumenta no momento do coffee break, em que eles compartilham experiências e uso da aprendizagem adquirida nas aulas, a exemplo dos role plays. Como é um momento de sociabilização, é imprescindível compartilhar esse momento entre envelhescentes e participantes da terceira idade. Ressalte-se, inclusive, que eles já ressignificaram suas vidas ampliando o nível social em outros dias de encontros extraclasse, fazendo, assim, um novo ciclo de amizade e aprendendo a viver e experienciar a terceira idade.

Gráfico 11: Testes emocionais dos participantes da terceira idade - Turma 2 (sex)

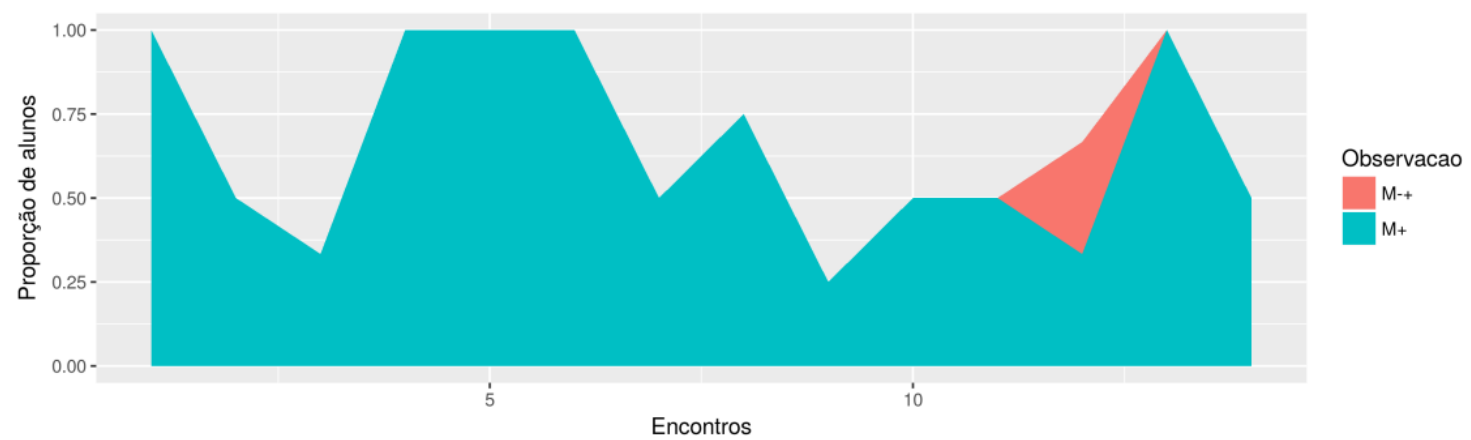

A área vermelha representa a proporção de mudanças emocionais tanto positivas quanto negativas (M+-). A área azul representa a proporção de mudanças positivas $(\mathrm{M}+)$

Já na turma 2, embora tenha como objetivo o mesmo da turma 1 - aprender a língua estrangeira -, a motivação não é igual, mas o grau de satisfação é preponderantemente positivo. A turma 2, por seus componentes serem apenas quatro alunos e por ainda estarem na fase laboral após a aposentadoria, eles participam das aulas pelo desejo de aprender um idioma, consciência sobre o bem cognitivo que todos possuem, bem como fazer parte de várias viagens internacionais e acesso à internet. $\mathrm{E}$ também leitura em artigos científicos. A mudança negativa é também por falta de estacionamento ou por problema pessoal (saúde e família).

Foi realizada uma correlação não paramétrica pelo método de Kendall entre a linha que representa as mudanças (tanto negativas como positivas, $\mathrm{M}+-$ ) e a linha que representa as mudanças positivas $(\mathrm{M}+)$. Os resultados obtidos apontam que, para a turma 1 , envelhescentes, a correlação foi de 0,581 significativa ( $\tau$ de Kendall $=0,5817, \mathrm{P}<0,001$ ) 
e para a terceira idade dessa mesma turma, a correlação foi de 0,795 significativa ( $\tau$ de Kendall $=0,79578, \mathrm{P}<0,001)$. Já na turma 2, a correlação foi de 0,919 significativa. Em todos os casos, a significância foi inferior a $\tau$ de Kendall $=0,05$ ( $\tau$ de Kendall $=0,91947$, $\mathrm{P}<0,001)$.

Em suma, os resultados da aplicação das fichas emocionais apontam que, de maneira geral, os participantes têm uma atitude positiva em relação ao curso, tanto na entrada como na saída (happy, hopeful, confident, surprised, smile, pleased, laughing). Nos dias em que a atitude de entrada foi negativa no teste de saída (angry, dejected, hungry, shy, confused, sad, disappointed), houve a mudança para atitudes positivas (happy, determined, hopeful). Esse comportamento pode ser explicado pelo fato de haver intervalos entre as aulas para o coffee break, quando os alunos têm a oportunidade de se sociabilizar e desempenhar role plays (reprodução dos aprendizados dos textos das aulas do curso de extensão em inglês). Tais resultados sugerem que a interação social entre os participantes de um curso de língua estrangeira para envelhescentes e pessoas da terceira idade, com as experiências e a sociabilização, pode contribuir para o bem-estar desse público, minimizando riscos de doenças, como depressão e demências do envelhecimento, o que pode ser explorado como uma política pública para a promoção de bem-estar social. 


\section{TEMPO SOCIAL E TEMPO COGNITIVO NA FORMAÇÃO DE PROFESSORES DE INGLÊS PARA A ENVELHESCÊNCIA E TERCEIRA IDADE}

Esta tese defende que é preciso formular políticas públicas que proporcionem uma formação especializada de professores para atender a envelhescentes e pessoas de terceira idade, tendo em vista suas necessidades pedagógicas específicas. Os resultados desta tese podem contribuir para o desenvolvimento de metodologias específicas de ensino, de modo que esse público seja tratado de forma humanística, conforme princípios da gerontagogia (PEREIRA, 2009).

Por isso, reiteramos que ensinar inglês para envelhescentes e pessoas da terceira idade é diferente de ensinar para crianças e adolescentes, tradicional público-alvo dos cursos de formação de professores. Como já dissemos, com o crescimento da população envelhescente e da terceira idade, é preciso preparar as pessoas que vão lidar com esse público. Vamos, agora, sumarizar os resultados de nossa pesquisa e sistematizar quais são as contribuições para a formação de professores.

Retomando os resultados do tempo de leitura silenciosa e em voz alta, constatamos que, embora existam diferenças entre os grupos de participantes, esse tempo, em milissegundos, não é suficiente para justificar a hipótese inicial de que envelhescentes e pessoas da terceira idade precisam de mais tempo para o desempenho das tarefas a serem executadas em leitura. Como dissemos, esse resultado em milissegundos pode ser relevante no caso de uma concessão de carteira de habilitação (um milissegundo de diferença pode causar um acidente, por exemplo), mas não para uma aula de inglês. $\mathrm{O}$ resultado obtido evidencia que a demanda de tempo de leitura não interfere na duração de tempo das aulas do curso de extensão, o que comprovamos também.

Esse resultado ajuda a desfazer o mito de que pessoas mais velhas são mais lentas e que por isso teriam mais dificuldades, necessitando de mais tempo para as atividades. Esse resultado contraria a hipótese e convicção da própria pesquisadora, que, como a maioria das pessoas, tinha a crença de que ao idoso deveria ser dado mais tempo para a execução de tarefas. Essa ideia pré-concebida e preconceituosa foi desfeita diante da evidência dos resultados. A mudança de concepção da pesquisadora é, também, um resultado. 
A investigação do número e da duração das fixações durante o movimento de leitura apontou que envelhescentes e pessoas de terceira idade realizam mais fixações com uma duração média maior. Os jovens fazem menos fixações do que os envelhescentes e pessoas da terceira idade, o que é natural da idade, devido à fisiologia humana e perdas da plasticidade muscular, o que explica essa diferença do tempo de leitura. Esse resultado corrobora a hipótese da perda de acurácia, devido à idade, pois, como vimos, fisiologicamente, músculos mais enrijecidos necessitam de um maior tempo. Novamente, destacamos que esse resultado pode contribuir para o desenvolvimento de materiais didáticos apropriados para o público. Em termos de formação de professores para atuarem com esse público, podemos destacar a necessidade de se considerar esse fator na hora de desenvolver materiais didáticos de suporte à leitura, com uma diagramação que permita movimentos confortáveis de sacadas (mancha da página mais estreita, por exemplo). Novas pesquisas precisam ser empreendidas nesse campo.

A crença de que o idoso necessita de mais tempo para a execução das tarefas, no que tange ao ensino de uma língua estrangeira, precisa ser desmistificada. Nas aulas do curso de extensão, constatamos que o tempo fora superdimensionado, pois, nas análises das tarefas dos planejamentos das aulas e aulas executadas, a hipótese inicial também foi desfeita. No entanto, observa-se que houve uma convergência entre esse estudo e o estudo de leitura: o tempo foi superior nas tarefas de teste emocional e coffee break e também nas revisões de gramática e novos vocabulários das novas lições. As primeiras atividades se referem ao tempo social, enquanto a última está voltada para questões pedagógicas, o que, de certa forma, seria esperado demandar menos tempo.

Quanto ao estado emocional, as análises dos testes de entrada e testes de saída das aulas mostram que os participantes chegam com motivações positivas e saem de maneira positivas também, e, quando chegam com motivações negativas, mudam para positivas. Esse cenário é diferente, por exemplo, de cursos regulares, com frequência obrigatória. No tipo de curso aqui analisado, os participantes vão espontaneamente. Assim, o professor que atua com esse público precisa ser preparado para manter a motivação desses participantes a fim de que não abandonem o curso, o que é diferente de motivar um participante que chega desmotivado.

Diversos autores discutem sobre a terceira idade e suas necessidades pedagógicas específicas. Pereira (2014) faz um levantamento histórico das últimas décadas do final do século XX sobre longevidade, destacando trabalhos científicos na área da "gerontologia básica" e um texto crítico sobre a universidade aberta. Lima (2001) evidencia a existência 
de um campo de estudos voltados a gerontologia educacional, que trata de uma pedagogia específica de ensino para os sujeitos de terceira idade. Stano (2001) relata questões voltadas ao envelhecimento e suas relações com o processo de ensino-aprendizagem no espaço escolar.

Knowles, Holton e Swanson (2005) apresentam cinco princípios de aprendizagem em adultos, ressaltando a importância da andragogia. O primeiro princípio se refere aos seus próprios interesses, necessidades de aprendizagem ou de continuidade de praticar a mesma ação. O segundo princípio diz respeito a uma aprendizagem autônoma ou por uma orientação de instrução de um especialista. O terceiro princípio visa à priorização das ferramentas ou recursos de aprendizagem e também como o seu ritmo de aprendizagem se processa. $\mathrm{O}$ quarto princípio de aprendizagem diz respeito à prontidão que esse público tem em relação às ações da vida e como suas tarefas são cumpridas. O quinto princípio é o problema central e contextual sobre uma orientação de aprendizagem para esse público.

Os princípios de aprendizagem da andragogia seguem as motivações necessárias de valor intrínseco, isto é, de dentro para fora, e sem espera de retorno financeiro. Os aprendizes desejam aprender com o prazer de se sociabilizarem com o outro e também de se sentirem úteis e participativos na vida, como sempre foram em outras faixas etárias passadas. Assim, terão qualidade de vida e o prazer de viver uma vida longeva.

Como em 2025 o Brasil passará a ser um país de idosos, novas demandas sociais surgirão, a exemplo da preocupação com a qualidade de vida dessa parcela da população. Pessoas já na terceira idade relatam que precisam dar um novo sentido para continuar vivendo de maneira independente e digna. Estão abertas a novos aprendizados e para isso estão dispostas a praticar o exercício da mente para o retardamento do envelhecimento da mente e do corpo. O acesso à educação, também por meio de cursos de língua estrangeira como o que ofertamos a esse público, contribui com a melhoria de sua qualidade de vida, já que podem aumentar sua autoestima, passam a ver o envelhecimento de forma mais natural e positiva, propicia sua integração social e dignidade humana, minimizando, por exemplo, riscos de doenças como depressão e demências do envelhecimento, o que pode ser explorado para a promoção de bem-estar social. 


\section{CONSIDERAÇÕES FINAIS}

O fator motivador desta tese foi a necessidade de se pensar na formação de professores de inglês para lidar com o público envelhescente e da terceira idade, visto que, em 2025, segundo as previsões demográficas do IBGE, teremos mais idosos do que jovens, o que causará a inversão da pirâmide etária brasileira. Assim, em um futuro não tão distante, não fará sentido formarmos professores de inglês para atuarem apenas com crianças, adolescentes e adultos jovens. Defendemos que há diferença em atuar com o público da envelhescência e da terceira idade e, por isso, nos propomos a investigar os efeitos do tempo cognitivo e do tempo social nas aulas de inglês, a fim de verificar como esses fatores interferem no tempo de leitura, no tempo de planejamento e nas emoções dos participantes.

Nossas hipóteses eram de que os participantes envelhescentes e da terceira idade demandariam mais tempo para a execução das tarefas, como a leitura, e essa demanda de tempo implicaria em maior tempo de execução das aulas. Nossa hipótese foi parcialmente confirmada: constatamos que, sim, os participantes envelhescentes e da terceira idade demandam mais tempo para a leitura, mas essa diferença, no contexto da sala de aula, não interfere na execução das tarefas durante a aula, visto que o tempo planejado foi superior ao tempo executado. Ou seja, as aulas estavam superdimensionadas em termos de tempo. Esse resultado revela o preconceito de que pessoas mais velhas são mais lentas, e esses preconceitos interferem no modo como concebemos o ensino de uma língua estrangeira.

Todo nosso estudo de revisão da literatura aponta para os benefícios do aprendizado de uma língua estrangeira no envelhescimento, com contribuições no retardo de processos degenerativos decorrentes do envelhecimento. Nosso estudo empírico, com a análise do tempo de leitura e movimento ocular, tempo de planejamento e as fichas emocionais, contribuiu para o aprimoramento do curso de inglês, com resultados pontuais que podem ser aproveitados para a implementação de componentes curriculares, com definições de conteúdo, procedimentos pedagógicos, preparação, adaptação e avaliação de material impresso e digital, bem como para se repensarem cursos de formação continuada de professores, semipresenciais e à distância, a fim de formar profissionais aptos a atuar em um novo mercado de trabalho, visando a um olhar retrospectivo e 
prospectivo, adaptando novas situações como inclusão social acadêmica e a não exclusão de conhecimento específico na língua estrangeira.

No atual mundo globalizado, é indispensável que tanto os graduandos como a comunidade interajam, com oportunidades de se engajarem em novos projetos voltados à continuidade da escolaridade, ou início de aprendizagem de uma segunda língua, como o inglês.

Viver feliz, sentindo-se inserido e bem recebido em todos os contextos educacionais familiares e sociais para se atingir uma terceira idade plena, com bem estar e qualidade de vida, de modo a fazer com que se sintam realizados, atuantes e mais integrados em seu meio social deve ser objetivo de todos. Se a sociedade conseguir proporcionar isso aos seus envelhescentes, haverá menos desgastes fisiológicos e cognitivos, menos problemas de saúde. O curso de inglês para a terceira idade contribui para essa realização.

Esperamos que com este estudo contribuamos para que futuros pesquisadores continuem as investigações e registros. Novas gerações vão chegando e desejamos que adiram à ideia de se preocupar com a qualidade de vida dos envelhecentes e pessoas de terceira idade. A oferta de cursos de inglês para esse público é uma das formas que contribui para isso. Enquanto pesquisadora, fui escolhida pelo público desde o meu ingresso na UFS, em 1993, a oferecer cursos de extensão livres muito antes de o Estatuto do Idoso entrar em vigor (Lei $\left.n^{\circ} 10.741 / 2003\right)$.

Pensemos no impacto social que já estamos vivendo. No ano 2025, professores, alunos, envelhescentes e pessoas da terceira idade terão o desejo de estar envolvidos com um aprendizado de uma língua estrangeira. Esperamos que esta proposta de estudo continue percorrendo a mente dos pesquisadores atuais e do futuro, mostrando que a pesquisa é contínua e inacabada.

O envelhecimento é inerente ao homem, portanto devemos aprender a respeitar os mais velhos e a envelhecer bem. Com essas palavras, não estou me despedindo, mas ratificando a relevância da pesquisa desenvolvida e do curso de extensão, sinalizando a continuidade dos estudos. Ainda há muito a ser feito. 


\section{REFERÊNCIAS}

ALTMANN, G. T.; GAMHAM, A.; DENNIS, Y. Avoiding the garden path: Eye movements in context. Journal of Memory and Language, v. 31, n. 5, p. 685-712, 1992.

AVILA, R. et al. Influence of education and depressive symptoms on cognitive function in the elderly. International Psychogeriatrics, v. 21, n. 3, p. 560-567, 2009.

BERGMAN, M. Aging and the perception of speech. Baltimore, MD: University of Maryland Press, 1980. 173 p.

BIALYSTOK, E.; CRAIK, F. I. M.; RUOCCO, A. C. Dual-modality monitoring in a classification task: The effects of bilingualism on aging. The Quaterly Journal of Experimental Psychology, v. 59, n. 11, p. 1968-1983, 2006.

BILLIG, J. D.; FINGER, I. Bilinguismo como potencial proteção contra o declínio da memória de trabalho no envelhecimento. Signo, v. 41, n. 71, p. 153-163, 2016.

BOWLES, R.; GRIMM, K. J.; MCARDLE, J. J. A structural factor analysis of vocabulary knowledge and relations to age. Journal of Gerontology: Psychological Sciences, s. B, v. 60 , n. 5 , p. $234-241,2005$.

BRASIL. Lei n. ${ }^{\circ} 10.741$, de $1^{\circ}$ de outubro de 2003. Dispõe sobre o Estatuto do Idoso e dá outras providências. Diário Oficial da República Federativa do Brasil, Brasília, 1 out. 2003.

BURKE, D. M.; SHAFTO, M. A. Aging and language production. Current Directions in Psychological Science, v. 13, n. 1, p. 21-24, 2004.

CAETANO, L. M. O Idoso e a Atividade Física. Horizonte: Revista de Educação Física e desporto, v. 11, n. 124, p. 20-28, 2006.

COELHO, F. G. M. et al. Desempenho cognitivo em diferentes níveis de escolaridade de adultos e idosos ativos. Revista Brasileira de Geriatria e Gerontologia, v. 15, n. 1, p. $7-15,2012$.

COLTHEART, M. Modelando a leitura: a abordagem da dupla rota. In: SNOWLING, M. J.; HULME, C. A ciência da leitura. Porto Alegre: Penso, 2013. p. 24-41.

COSTA LIMA, G. A. Do velho ao idoso. São Paulo: Paco, 2014. 128 p.

COWLES, H. W. Psycholinguistics 101. Nova York: Hamilton Printing, 2011. 208 p.

CUNNINGSWORTH, A. Evaluating and selecting EFL teaching materials. London: Heinemann Educational Books, 1984. 104 p.

DEBERT, G. G. Gênero e envelhecimento: os programas para a terceira idade e o movimento dos aposentados. Revista Estudos Feministas, n. 3, v. 2, p. 33-51, 1994.

DEBERT, G. G. A Reinvenção da Velhice: Socialização e Processos de Reprivatização do Envelhecimento. São Paulo: USP/FAPESP, 2004. 272 p.

DEHAENE, S. Os neurônios da leitura: como a ciência explica a nossa capacidade de ler. Tradução: Leonor Scliar Cabral, Porto Alegre: Penso, 2012. 372 p. 
EHRLICH, S. E.; RAYNER, K. Contextual effects on word perception and eye movements during reading. Journal of Verbal Learning and Verbal Behavior, v. 20, p. 641-655, 1981.

ENGELHARDT, E.; LAKS, J.; ROZENTHAL, M.; MARINHO, V. Quantas Demências Degenerativas? Doença de Alzheimer e Outras Demências : Considerações Diagnósticas. Informação Psiquiátrica, v. 17, n. Sup11, p. S10-S20, 1998.

FRANGE, P. O Estatuto do Idoso Comentado, São Paulo, 2010. 112 p. Disponível em: $<$ www.paulofrange.com.br/Livroidosofinal.pdf $>$. Acesso em 7 maio 2015.

FRAZIER, L.; RAYNER, K. Making and correcting errors during sentence comprehension: Eye movements in the analysis of structurally ambiguous sentences. Cognitive Psychology, v. 14, n. 2, p. 178-210, 1982.

FREITAG, R. M. K. Metodologia de coleta e manipulação de dados em Sociolinguística. São Paulo: Blucher, 2014.

FREITAG, R. M. K. Documentação Sociolinguística, coleta de dados e ética em pesquisa. São Cristóvão: EdUFS, 2017.

FREITAG, Raquel Meister Ko et al. Teste cloze e a competência em leitura de universitários: uma experiência no curso química/licenciatura da UFS/Itabaiana. InterSciencePlace, v. 1, n. 30, 2015.

FREITAG, Raquel Meister Ko et al. Diagnóstico da competência de leitura de prévestibulandos: experiência no Pré-SEED em Itabaiana, Estado do Sergipe. Acta Scientiarum. Language and Culture, v. 32, n. 2, p. 233-240, 2010.

GABRIEL, R. Uma leitura introdutória ao paradigma conexionista. Signo, v. 29, n. 47, p. 71-98, 2004.

GOLDSTEIN, L. L. L. Estresse, Enfrentamento e Satisfação de Vida Entre Idosos: Um estudo do Envelhecimento Bem Sucedido. 1995. 129 f. Tese (Doutorado em Educação) - Faculdade de Educação, Universidade Estadual de Campinas - UNICAMP, Campinas. 1995.

GONDIM, S.; LOIOLA, E.; BORGES-ANDRADE, J. E. Emoções e aprendizagem em contextos sociais: aspectos conceituais. In: GONDIM, S.; LOIOLA, E. Emoções, aprendizagem e comportamento social: conhecendo para melhor educar nos contextos escolares e de trabalho. São Paulo: Casa do Psicólogo, 2015. p 17-51.

GOODMAN, K. S. Reading: A psycholinguistic guessing game. Journal of the Reading Specialist, v. 6, n. 4, p. 126-135, 1967.

HADDAD, S. A educação de pessoas jovens e adultas e a nova LDB. In: BRZEZINSKI. I. (org). LDB interpretada: diversos olhares se entrecruzam. São Paulo: Cortez, 1997, p. 106-122.

HADDAD, E. G. M. A Ideologia da Velhice. São Paulo: Cortez, 1986. 134 p.

HARLEY. Trevor A. The Psycology of Language: From data to Theory. 2009. U.S.A. \& Canadá: Psycology Press. 603 p.

IBGE - Instituto Brasileiro de Geografia e Estatística. Censo Demográfico - 2010. Rio de Janeiro: IBGE. Disponível em: <https://censo2010.ibge.gov.br/>. Acesso em: 15 jul. 2016. 
INHOFF, A. W.; RAYNER, K. Parafoveal word processing during eye fixations in reading: Effects of word frequency. Perception \& Psychophysics, v. 40, n. 6, p. 431439, 1986.

IZQUIERDO I. Memória. 2. ed. Porto Alegre: Artes Médicas, 2011. 133 p.

IZQUIERDO I. Questões sobre memória. Coleção Aldus. São Leopoldo: Unisinos, 2004. $128 \mathrm{p}$.

JUHASZ, B. J.; RAYNER, K. Investigating the effects of a set of intercorrelated variables on eye fixation durations in reading. Journal of Experimental Psychology: Learning, Memory \& Cognition, v. 29, n. 6, p. 1312-1318, 2003.

JUHASZ, B. J.; RAYNER, K. The role of age of acquisition and word frequency in reading: Evidence from eye fixation durations. Visual Cognition, v. 13, n. 7-8, p. 846$863,2006$.

JUST, M. A.; CARPENTER, P. A. A theory of reading: From eye fixations to comprehension. Psychological Review, v. 87, n.4, p. 329-354, 1980.

KNOWLES, M.; HOLTON III, E. F.; SWANSON, R. A. The Adult Learner. 6 ed. London: Elsevier, 2005. 366 p.

LA BERGE, D.; SAMUELS, S. J. Toward a theory of automatic information process in reading. Cognitive Psychology, v. 6, n. 2, p. 293-323, 1974.

LAWTON, M. P. A multidimensional view of quality of life in frail elderly. In: BIRREN, J. E.; LUBBEN, J. E.; ROWE, J. C.; DEUTCHMANN, D. E. The concept and measurement of quality of life in the frail elderly. San Diego, CA: Academic Press, 1991. p. 3-27

LEFFA, V. J. Aspectos da Leitura: Uma Perspectiva Psicolingüística. 1. ed. Porto Alegre: Sagra/Luzzatto, 1996. 105p.

LENT, R. Cem bilhões de neurônios: conceitos fundamentais de neurociência. São Paulo: Atheneu, 2005.

LIMA, M. P. Reformas paradigmáticas na velhice do século XXI. In: KACHAR, V. Longevidade: um novo desafio para Educação. São Paulo: Cortez, 2001. p. 15-26.

MENDES, T. M. S. Da adolescência à envelhescência: convivência entre as gerações na atualidade. Porto Alegre: Mediação, 2012. 176 p.

MURPHY, Raymond. Essential grammar in use CD-Rom with answers. Cambridge: Cambridge Press, 2007.

NERI, A. L. ; FREIRE, S. A. E por falar em boa velhice. Campinas: Papirus, 2000. 132 p.

OBLER, L. K.; PEKKALA, S. Language and Communication in Aging. In: STEMMER, B.; WHITAKER, H. A. Handbook of the Neuroscience of Language. London: Academic Press, 2008. p. 351-358.

PEIXOTO, C. Entre o estigma e a compaixão e os termos classificatórios: velho, velhote, idoso, terceira idade. In: BARROS, M. M. L. Velhice ou terceira idade? Estudos antropológicos sobre identidade, memória e política. Rio de Janeiro: Fundação Getúlio Vargas Editora, 1998. p. 69-84.

PEREIRA, E. T. A Terceira idade na Universidade Aberta: Navegando, Buscando, Aprendendo em um Mar Sem Fim. 2009. 229 f. Tese (Doutorado em Linguística Aplicada 
e Estudos da Linguagem) - Pontifícia Universidade Católica de São Paulo - PUC, São Paulo. 2009.

PEREIRA, E. T. Terceira idade na Universidade Aberta: Navegando, Buscando, Aprendendo em um Mar Sem Fim. São Paulo: Paco Editorial, 2014. 124 p.

PIZZOLATTO, C. E. A sala de aula de língua estrangeira com adultos da terceira idade. In: ROCHA, H. C.; BASSO, A. E. Ensinar e aprender língua estrangeira nas diferentes idades: reflexões para professores e formadores. São Carlos: Editora Claraluz, 2008. p. 237-255.

PONTAROLO, R. S.; OLIVEIRA, R. C. Terceira idade: uma breve discussão. Publicatio UEPG: Ciências Sociais Aplicadas, v. 16, n. 1, p. 115-123, 2008.

PORTO, M. A. R. Um ensino do idioma inglês: seu papel na inclusão social. Interdisciplinar: Revista de Estudos de Língua e Literatura, v. 17, p. 469-478, 2012.

PRATA, M. Cem melhores crônicas. Cartaz Editorial/Jornal. São Paulo: Planeta do Brasil, p. 60-61, 2007.

RAYNER, K. Eye Movements in Reading and Information Processing: 20 Years of Research. Psychological Bulletin, n. 124, p. 372-422, 1998.

RAYNER, K.; CHACE, K. H.; SLATTERY, T. J. Eye Movement as Reflections of Comprehension Processes in Reading. Scientific Studies of Reading, n. 10, v. 3, p. 241255, 2006.

RAYNER, K.; DUFFY, S. A. On-line comprehension processes and eye movements in reading. In: DANEMAN, M.; MACKINNON, G. E.; WALLER, T. G. Reading research: Advances in theory and practice. New York: Academic Press, 1988. p. 13-66.

RAYNER, K.; JUHASZ, B. J.; POLLATSEK, A. Movimentos Oculares durante a leitura. In: SNOWLING, M. J.; HULME, C. A ciência da leitura. Porto Alegre: Penso, 2013. p. 97-116.

RAYNER, K.; SERENO, S. C. Regressive eye movements and sentence parsing: On the use of regression-contingent analyses. Memory \& Cognition, v. 22, n. 33, p. 281-285, 1994.

RAYNER, K.; WELL, A. D. Effects of contextual constraint on eye movements in reading: A further examination. Psychonomic Bulletin \& Review, v. 3, n.4, p. 504-509, 1996.

REIS, L. A. et al. Rastreamento cognitivo de idosos institucionalizados no município de Jequié-BA. Psicologia em estudo, v. 14, n. 2, p. 295-301, 2009.

ROCHA, A. G. Os conectores temporais em textos narrativos: o uso dos advérbios como mecanismo de coesão sequencial na escrita de alunos do $7^{\circ}$ ano do Ensino Fundamental. 2018. Dissertação (Mestrado profissional em Letras), PROFLETRAS Universidade Federal de Sergipe - UFS, Aracaju, 2018.

ROCHA, F. J. M. Ortografia para o mercado de trabalho. 2016. Dissertação (Mestrado profissional em Letras), PROFLETRAS - Universidade Federal de Sergipe - UFS, Aracaju, 2016

SANTOS, C. C.; ROSSETTI, C. B.; ORTEGA, A. C. O funcionamento cognitivo de idosos e de adolescentes num contexto de jogo de regras. Estudos Interdisciplinares sobre o Envelhecimento, v. 9, p. 53-74, 2006. 
SCHERER, L. C.; GABRIEL, R. Processamento da linguagem: contribuições da neurolinguística. Signo, v. 32, n. 53, p. 66-81, 2007.

SCHONS, C. R.; PALMA, L. T. S. Conversando com Nara Costa Rodrigues sobre gerontologia social. 2 ed. Passo Fundo: UPF, 2000. 180 p.

SILVA, A. L. G. Histórias de Leitura na Terceira idade: memórias individuais e coletivas. Jundiaí: Paco, 2015. 228 p.

SILVA, N. L. S. Educação da Terceira Idade: Inclusão Social e Inovação Pedagógica na Universidade. Aracaju: Editora Diário Oficial do Estado de Sergipe - Edise, 2016.

STANO, R. C. M. T. Espaço escolar: um tempo de ser-na-velhice. In: KACHAR, V. Longevidade: um novo desafio para Educação. São Paulo: Cortez, 2001. p. 155-168.

THE WHOQOL GROUP. The World Health Organization Quality of Life assessment (WHOQOL): Development and general psychometric properties. Social Science and Medicine, v. 46, n. 12, p. 1569-1585, 1998.

TODOS PELA EDUCAÇÃO. Anuário Brasileiro de Educação Básica- 2016. São Paulo: Editora Moderna, 2016.

TODOS PELA EDUCAÇÃO. Anuário Brasileiro de Educação Básica- 2017. São Paulo: Editora Moderna, 2017.

UR, P.; WRIGHT, A. Five-Minute Activities: A Resource Book of Short Activities. 23rd ed. edition ed. Cambridge: New York: Cambridge University Press, 1992.

VIEIRA, R. S.; LIMA, M. E. O. Estereótipos sobre os idosos: dissociação entre crenças pessoais e coletivas. Temas em Psicologia, v. 23, n. 4, p. 947-958, 2015.

VILLANI, F. L. A longevidade no aprendizado de línguas: acrescentando vida aos anos e não anos a vida. Linguística aplicada e Estudos da Linguagem. 2007. 278 f. Tese (Doutorado em Linguística). Pontifícia Universidade Católica de São Paulo, 2007.

VONK, W; COZIJN, R. On the treatment of saccades and regressions in eye movement measures of reading time. In: RADACH, R.; HYONA J.; DEUBEL H. The mind's eye: Cognitive and applied aspects of eye movement research. Amsterdam: North Holand, 2003. p. 291-312

VIGOTSKI, L. S. A construção do pensamento e da linguagem. [1934] Tradução de Paulo Bezerra. São Paulo: Martins Fontes, 2000. 521 p.

WINGFIELD, A.; PEELLE, J. E.; GROSSMAN M. Speech rate and syntactic complexity as multiplicative factors in speech comprehension by young and older adults. Aging, Neuropsychology, and Cognition. n. 10, v. 4, p. 310-322, 2003

XAVIER, F. M. F. O transtorno cognitivo da depressão geriátrica ou a pseudodemência depressiva do idoso. In: PARENTE, M. A. M. P, Cognição e envelhecimento. Porto Alegre, RS: ArtMed, 2006. 205-224 p. 
ANEXOS 


\section{ANEXO 1 - PARECER CEP/CONEP}







\section{ANEXO 2 - MAPA DE POSICIONAMENTO EM CLASSE}

UNIVERSIDADE FEDERAL DE SERGIPE

\section{CECH - DLES}

PRO REITORIA DE EXTENSÃO - PROEX

Projeto de Extensão - "A Aula de Inglês para a Terceira Idade". MAPA DE CLASSE

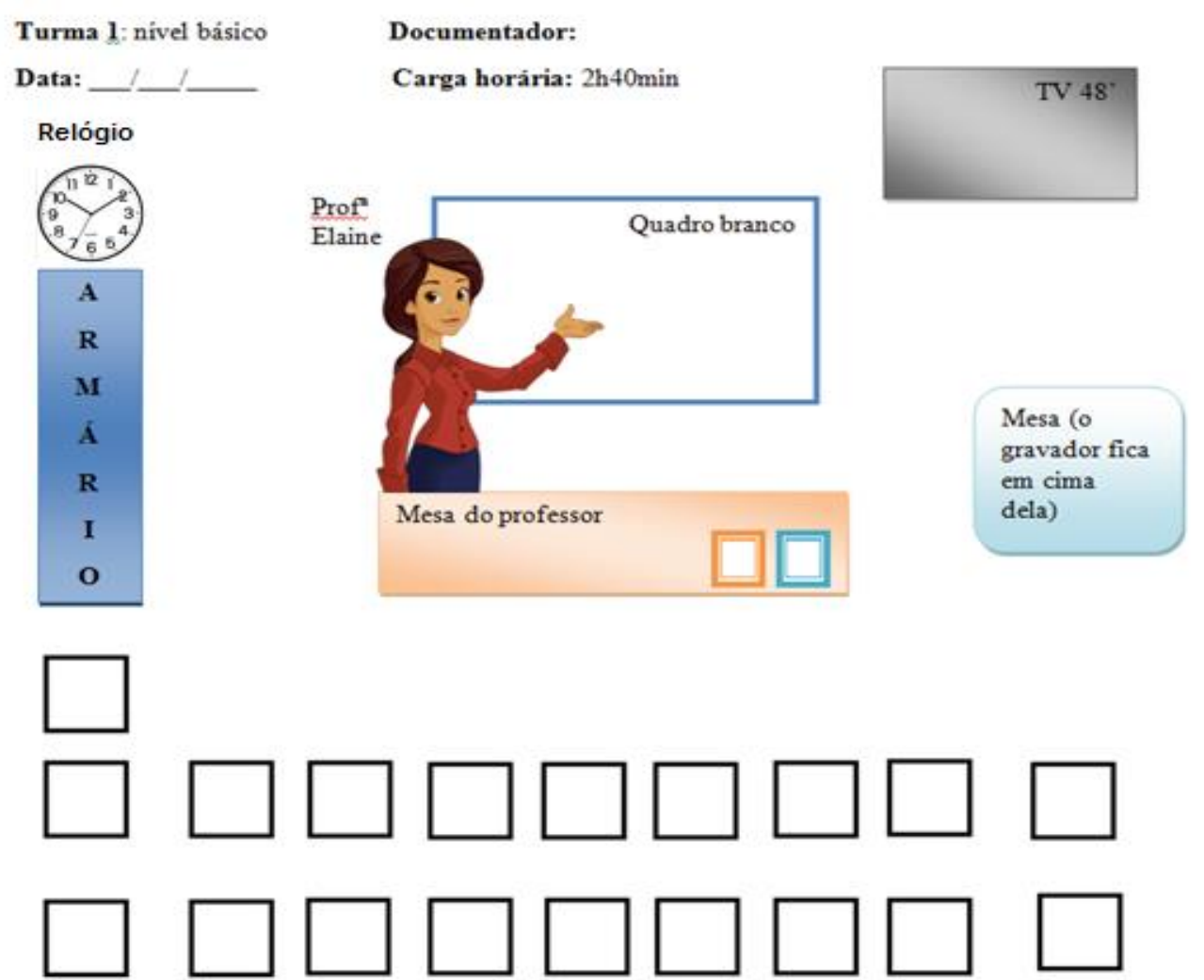

Legenda:

$1=$ Val

$2=$ Sol

$3=\mathbf{E l i} / \mathbf{C}$

$4=\mathrm{Sol} / \mathrm{F}$

$\mathbf{5}=\mathbf{M} / \mathbf{F}$

$6=\mathrm{J} / \mathrm{A}$

$7=$ Mar

$8=$ Ang

$9=\mathrm{Ilm}$

$10=\mathbf{V} / \mathrm{L}$

$11=\mathrm{Neu} / \mathrm{R}$

$12=\mathbf{E l i} / \mathrm{M}$

$13=\mathrm{Neu} / \mathrm{S}$

$14=$ Cél

$15=\mathrm{M} / \mathrm{I}$

$16=$ Âng 


\section{ANEXO 3 - FICHAS EMOCIONAIS}

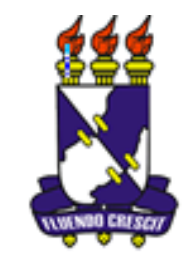

UNIVERSIDADE FEDERAL DE SERGIPE

CECH - DLES

PRO REITORIA DE EXTENSAO - PROEX

PROJETO DE EXTENSÄO - "A AULA DE INGLËS PARA A TERCEIRA

IDADE".

FICHA EMOCIONAL

Hello, Good moming! How are you today?

Cheose a picture that better show us how you are feeling todav and paint it.
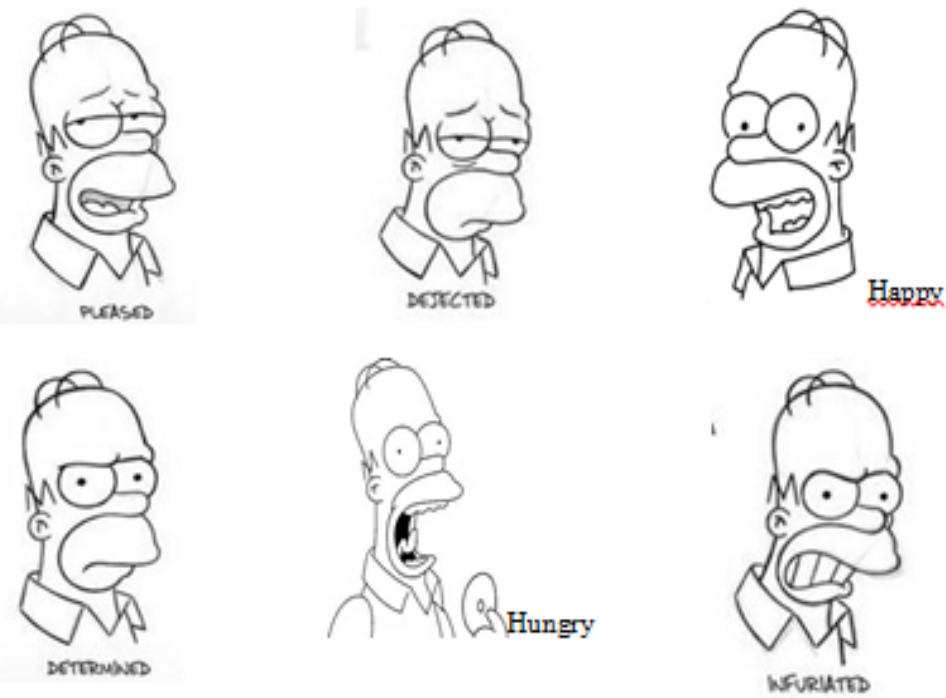

Would you like to talk about it?

How are you feeling now, after class? 


\title{
ANEXO 4 - FICHA DO DOCUMENTADOR
}

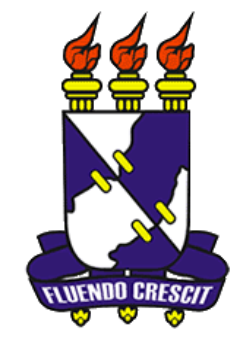

\author{
UNIVERSIDADE FEDERAL DE SERGIPE \\ PRÓ-REITORIA DE EXTENSÃO \\ PROJETO DE EXTENSÃO “A AULA DE INGLÊS PARA A TERCEIRA IDADE”
}

\section{FICHA DO DOCUMENTADOR}

Neste modelo de ficha, elaboramos duas outras com os nomes: fichas de ministrantes e ficha de pesquisador, para anotações, observações e ocorrências.

Turma 1: nível básico

\section{Documentador:}

Data: 07/03/2016

\section{Carga horária: $2 \mathrm{~h} 40 \mathrm{~min}$}

Objetivos: - Aplicar o teste de sondagem para observar a aprendizagem dos conteúdos ao longo do curso. Entrevistar os alunos de maneira informal e individualmente os alunos. Exercitar a oralidade e fluidez no idioma inglês.

\begin{tabular}{|c|c|c|}
\hline $\begin{array}{c}\text { Atividades } \\
\end{array}$ & Tempo & Anotações \\
\hline $\begin{array}{l}\text { 8:00 - Aplicação da ficha } \\
\text { emocional. }\end{array}$ & $\begin{array}{l}\text { Início: } \\
\text { Fim: }\end{array}$ & \\
\hline $\begin{array}{l}\text { 8:10 - Aplicação do teste de } \\
\text { sondagem } \\
\text { (primeiro momento). }\end{array}$ & $\begin{array}{l}\text { Início: } \\
\text { Fim: }\end{array}$ & \\
\hline 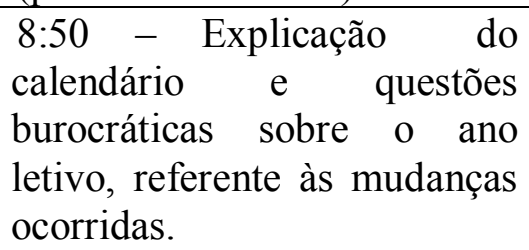 & $\begin{array}{l}\text { Início: } \\
\text { Fim: }\end{array}$ & \\
\hline $\begin{array}{l}\text { 9:00 - Aplicação do teste de } \\
\text { sondagem } \\
\text { (segundo momento). }\end{array}$ & $\begin{array}{l}\text { Início: } \\
\text { Fim: }\end{array}$ & \\
\hline $\begin{array}{l}\text { 9:40 - Execução da atividade } \\
\text { extra. }\end{array}$ & $\begin{array}{l}\text { Início: } \\
\text { Fim: }\end{array}$ & \\
\hline $\begin{array}{l}\text { 10:00 - Aplicação da ficha } \\
\text { emocional }\end{array}$ & $\begin{array}{l}\text { Início: } \\
\text { Fim: }\end{array}$ & \\
\hline 10:10-Coffee break. & $\begin{array}{l}\text { Início: } \\
\text { Fim: }\end{array}$ & \\
\hline
\end{tabular}




\title{
ANEXO 5 - PLANEJAMENTO DA AULA
}

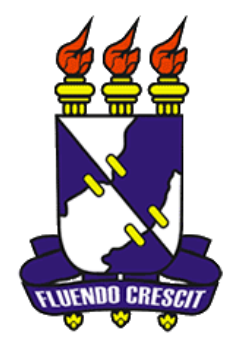

\author{
UNIVERSIDADE FEDERAL DE SERGIPE \\ CECH - DLES \\ PRO REITORIA DE EXTENSÃO - PROEX \\ Projeto de Extensão - “A Aula de Inglês para a Terceira Idade”.
}

PLANO DE AULA

Turma 1: nível básico

Data: 07/03/2016

Carga horária: $2 \mathrm{~h} 30 \mathrm{~min}$

- Objetivos:

- Aplicar o teste de sondagem para observar a aprendizagem dos conteúdos ao longo do curso.

- Entrevistar de maneira informal e individualmente os alunos.

- Exercitar a oralidade e fluidez no idioma inglês.

- Conteúdo

- Vocabulários diversos que foram mostrados durante o curso (review):

- Greetings

- Numbers/colors

- Days of the week/months of the year/seasons

- Simple present

- Articles (a/an/the)

- Quantifiers (many/much/lots of)

- Metodologia

A aula será ministrada de forma dinâmica para que possa contemplar as quatro habilidades linguísticas. 
8:00 - Aplicar a ficha emocional (primeiro momento) utilizando uma atividade lúdica como desenhar, pintar, escrever uma frase e /ou palavra para descrever suas emoções no início da aula, etc.

8:10 - Aplicar o teste de sondagem (primeiro momento) com questões referentes à aprendizagem da língua inglesa, que devem ser respondidas (escritas) individualmente.

8:40 - Explicar o calendário e questões burocráticas sobre o ano letivo, referente às mudanças ocorridas.

9:00 - Aplicar o teste de sondagem (segundo momento).

Atividade em forma de entrevista individual/coletiva na qual o aluno usará os conhecimentos adquiridos ao longo do curso para a prática do inglês.

9:40 - Execução da atividade extra.

10:00 - Aplicar a ficha emocional (segundo momento).

10:10 - Coffee break.

- Atividade extra: questões referentes às entrevistas feitas na aula.

- Recursos didáticos

Quadro branco, pincel, questionário escrito. 


\section{ANEXO 6 - ESTÍMULOS DO TESTE DE LEITURA}

\section{EXPERIMENTOS INGLÊS - PARTICIPANTE CEL}

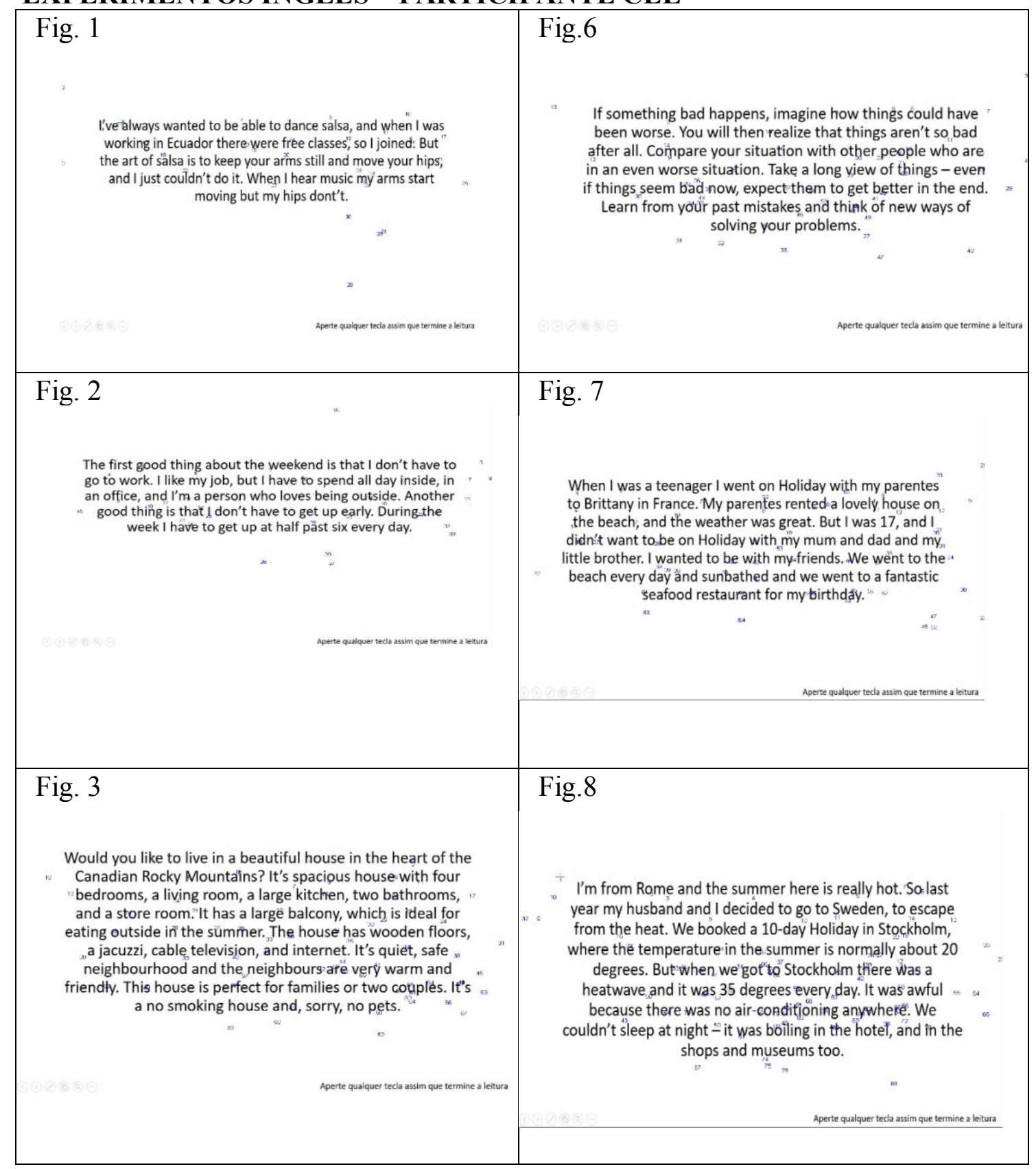




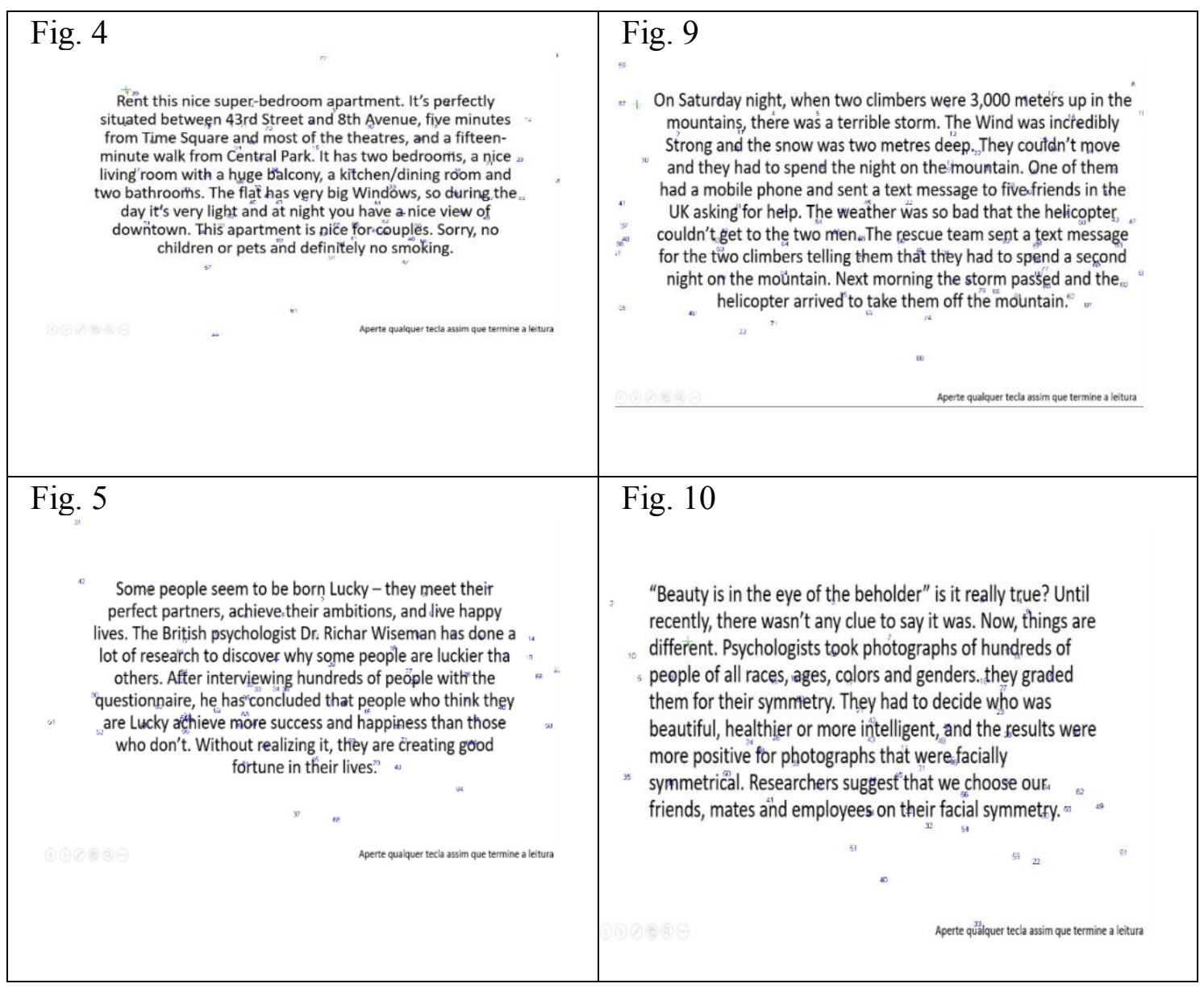




\section{EXPERIMENTOS PORTUGUÊS - PARTICIPANTE CEL}

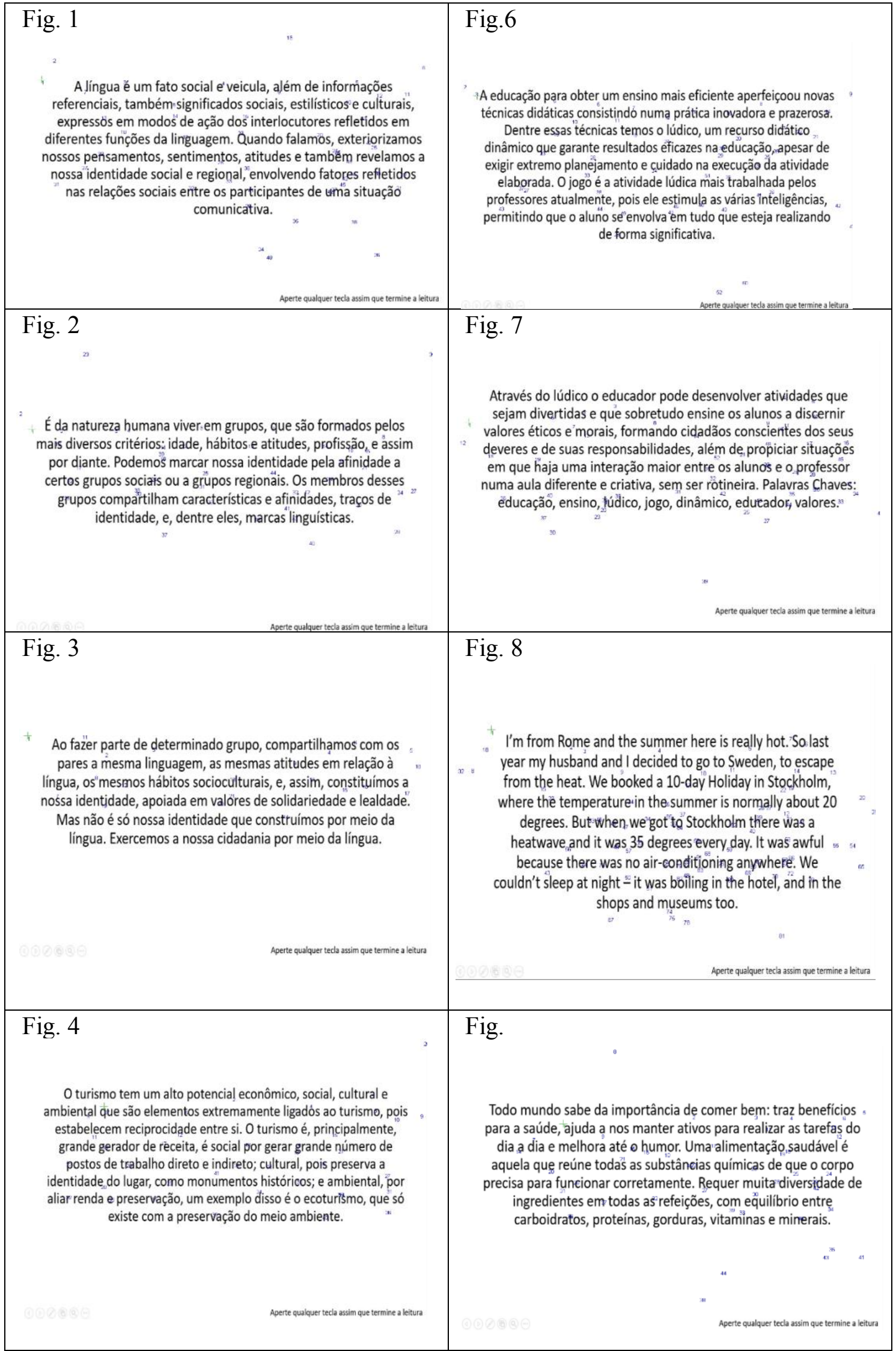




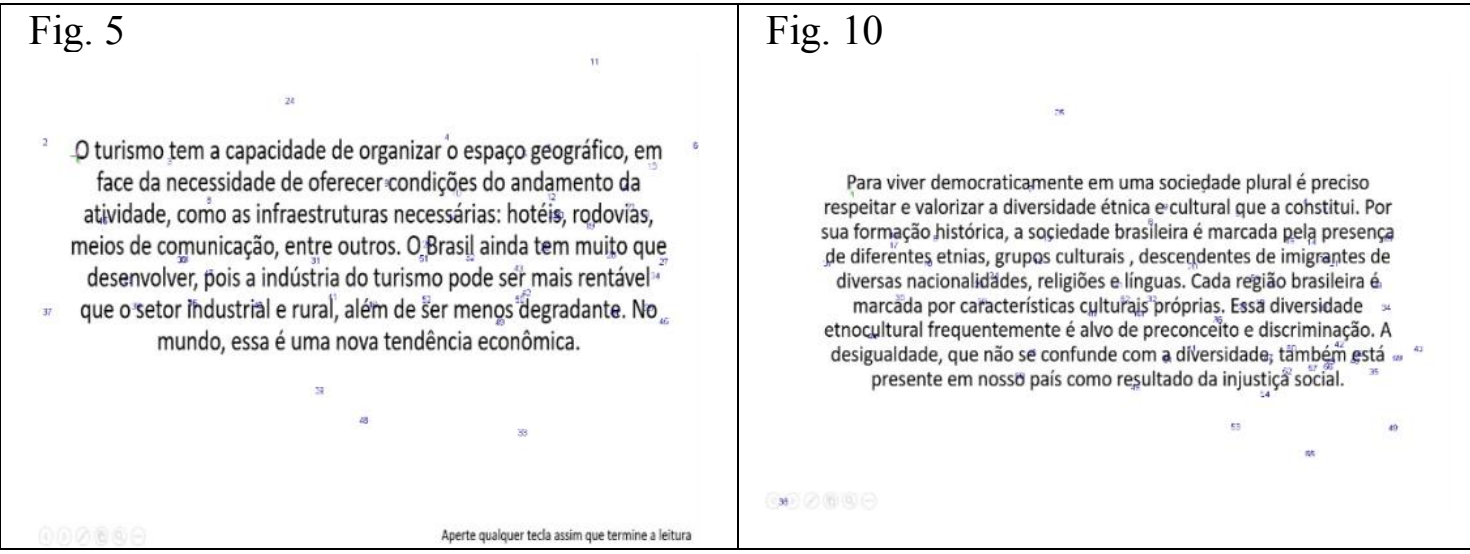


